Portland State University

PDXScholar

Summer 8-13-2013

\title{
CCAAT/Enhancer-Binding Protein Delta (C/EBP- delta) Expression in Antarctic Fishes: Implications for Cell Cycle and Apoptosis
}

Isaac Martin Sleadd

Portland State University

Follow this and additional works at: https://pdxscholar.library.pdx.edu/open_access_etds

Part of the Aquaculture and Fisheries Commons, Climate Commons, and the Marine Biology Commons

Let us know how access to this document benefits you.

\section{Recommended Citation}

Sleadd, Isaac Martin, "CCAAT/Enhancer-Binding Protein Delta (C/EBP-delta) Expression in Antarctic Fishes: Implications for Cell Cycle and Apoptosis" (2013). Dissertations and Theses. Paper 994. https://doi.org/10.15760/etd.994

This Dissertation is brought to you for free and open access. It has been accepted for inclusion in Dissertations and Theses by an authorized administrator of PDXScholar. Please contact us if we can make this document more accessible: pdxscholar@pdx.edu. 
CCAAT/Enhancer-Binding Protein Delta (C/EBP- $\Delta$ ) Expression in Antarctic

Fishes: Implications for Cell Cycle and Apoptosis

by

Isaac Martin Sleadd

A dissertation submitted in partial fulfillment of the requirements for the degree of

Doctor of Philosophy

in

Biology

Dissertation Committee:

Bradley Buckley, Chair

Suzanne Estes

Todd Rosenstiel

Jason Podrabsky

Andrew Fountain

Portland State University

2013 
(C) 2013 Isaac Martin Sleadd 


\section{Abstract}

Chapter 1: Antarctic fishes are extremely cold adapted. Despite their inability to upregulate heat shock proteins, recent studies have demonstrated a capacity for heat response in these animals. A cDNA microarray study looked at the Notothenioid fish Trematomus bernacchii and revealed heat sensitivities for hundreds of genes, two of which code for members of the CCAAT/Enhancer-binding protein (C/EBP) family of transcription factors. These molecular switches are best known for their roles in apoptosis, inflammation and cell cycle arrest. This dissertation further elucidates the role of C/EBP- $\delta$ in the Antarctic fishes T. bernacchii and Pagothenia borchgrevinki.

Chapter 2: C/EBP- $\delta$ is constitutively expressed in unstressed, fieldacclimated (ca. $-1.86^{\circ} \mathrm{C}$ ) animals in a highly tissue-specific manner. White muscle tissue contains the highest C/EBP- $\delta$ concentration, which is further increased in response to sublethal heat stress at 2.0 or $4.0^{\circ} \mathrm{C}$. This response is mostly acute and transitory, but a lesser upregulation was observed in fishes held for one month at $4.0^{\circ} \mathrm{C}$. 
Chapter 3: The heat-induced nuclear translocation of C/EBP- $\delta$--as

determined by immunohistochemistry--appears to be time, tissue and species specific with spleen, heart and retinae being particularly responsive in certain situations.

Chapter 4: Protein concentrations of proliferating cell nuclear antigen are tissue specific and variably heat responsive. Surprisingly, levels appear to be positively correlated with C/EBP- $\delta$.

Chapter 5: Flow cytometry revealed increasingly high temperatures reduce the proportion of G1 cells while increasing the abundance of apoptotic cells.

Chapter 6: These findings are discussed in the context of global climate change and the cellular stress response. 
This dissertation is dedicated to my grandmother Dr. Gwen Curry, who passed away suddenly just days before its completion. Words are not capable of describing the ways in which she blessed the lives of those who were fortunate enough to know her. To Gwen's daughter, my mother Marcie McGuire, who, with her deep and gentle love, has always guided me along life's tortuous paths. To my father Mike Sleadd, whose kindness and laughter will continue to shake the Earth and make it a better place. To my wife Sandra Keeney, who taught me what it means to love one's best friend. To my brother Matthew and all my remaining family and friends, who are too numerous to list here. I love you all. Thank you for supporting me. 


\section{Acknowledgements}

My sincerest thanks to my committee: Drs. Bradley Buckley, Suzanne Estes, Jason Podrabsky, Todd Rosenstiel and Andrew Fountain. This research was supported by in-house funds at Portland State University, NSF-OPP grant \#0443754 and Medical Research Foundation OHSU grant \#0801 to Bradley A. Buckley, as well as a Scholarly and Creative Activity grant award from Portland State University to me, Isaac M. Sleadd.

I am grateful to the entire staff of McMurdo Station, in particular the staff of Crary Lab for laboratory assistance and to the members of B-134 and B-308 for both laboratory assistance and help with field collections.

Included in the latter are Allison "Sandwich" Barden and Amanda Kelley, without whom this work would have been impossible or much less enjoyable, anyway. Dan Hassumani and Marissa Lee assisted with the collection and maintenance of fishes during the 2011/2012 field season in Antarctica. Undergraduate students Chelsea Arakawa, Jess Millar, Litzy Venturi, Tonya Stecyk and Otto Zietz helped immensely with various aspects of sample preparation, data collection and statistical analysis. I want to thank Barbra Mason at Oregon Health Sciences University for producing 
the tissue sections utilized in chapter three of this dissertation. Dr. Jason Podrabsky was kind enough to let me use his microscope and software. At Hopkins Marine Station, Dr. George Somero and others were very hospitable when Dr. Buckley and I conducted some pilot experiments there in 2008. Thank you. 


\section{Table of Contents}

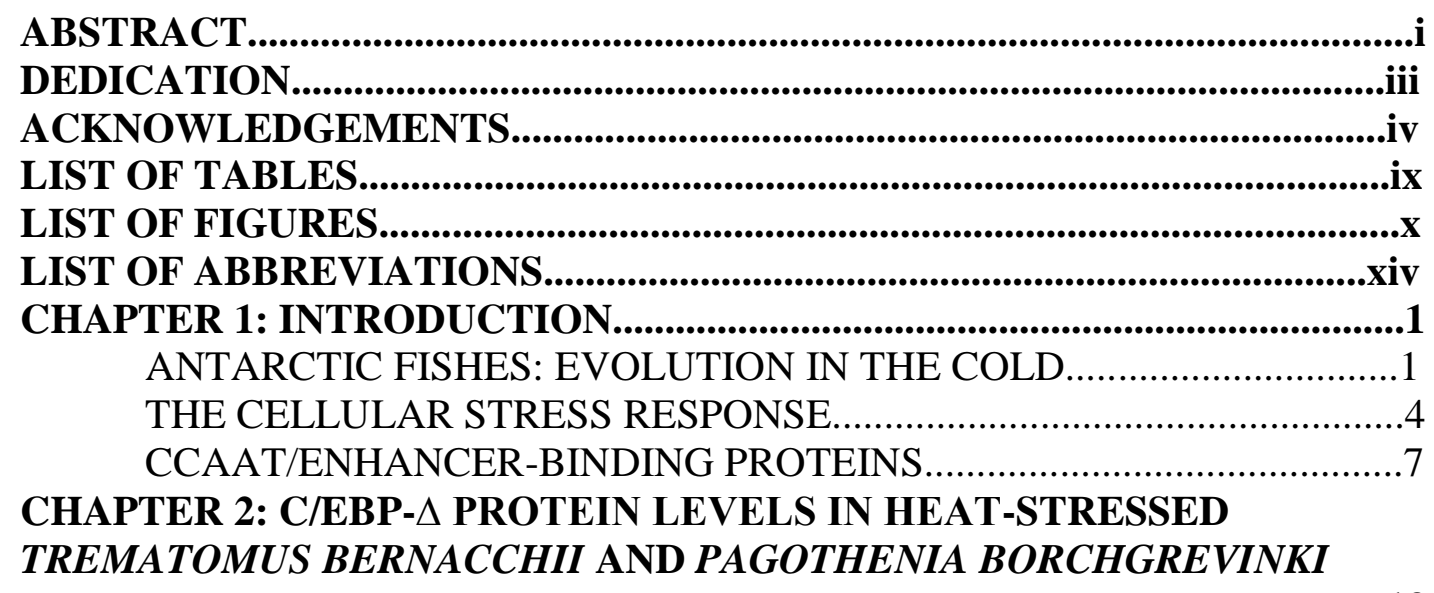

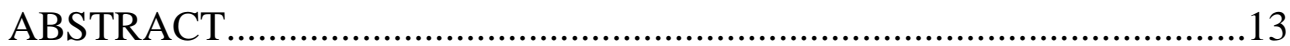

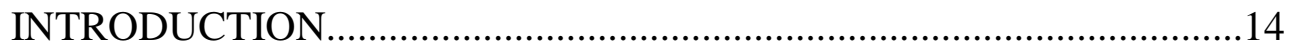

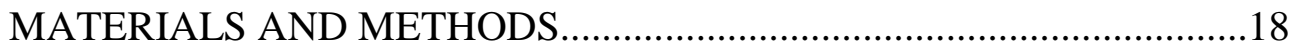

Animal collection .......................................................................18

Short-course heat shock with recovery...........................................19

Long-course heat shock................................................................20

Long-term heat acclimation............................................................20

Protein quantification via western blotting.......................................21

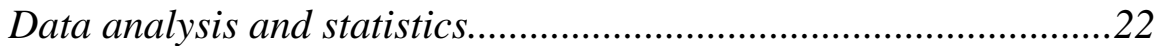

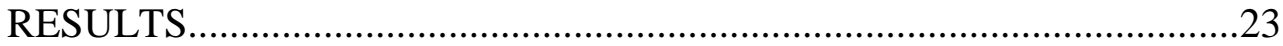

Short-course heat shock with recovery............................................23

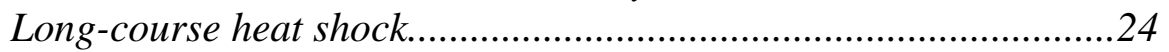

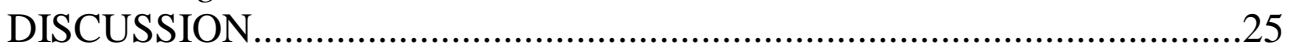

Constitutive expression of $C / E B P-\delta$ in field-caught specimens........26

Heat-induction of $C / E B P-\delta \ldots \ldots \ldots \ldots \ldots \ldots \ldots \ldots \ldots \ldots \ldots \ldots \ldots \ldots \ldots \ldots \ldots \ldots \ldots . .28$

CHAPTER 3: NUCLEAR ACCUMULATION OF C/EBP- $\triangle$ IN HEAT

STRESSED DANIO RERIO, TREMATOMUS BERNACCHII AND

PAGOTHENIA BORCHGREVINKI.................................................................32

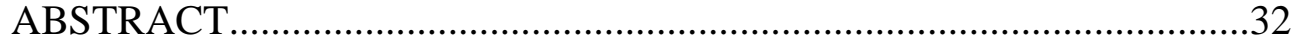

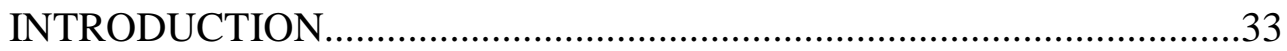

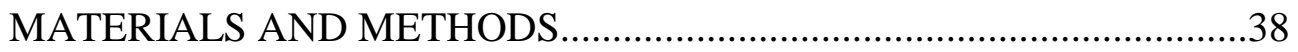

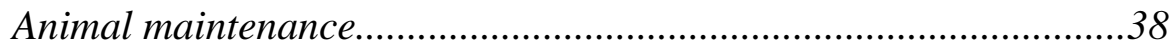

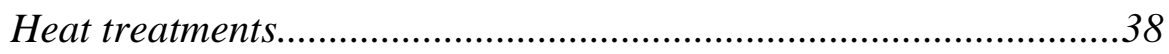

Tissue fixation and slide preparation...............................................39

Immunohistochemistry...................................................................40

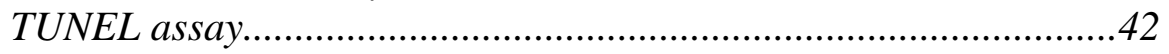

Image acquisition and manipulation.............................................42 


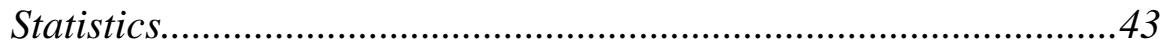

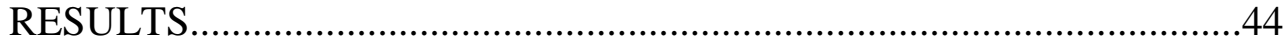

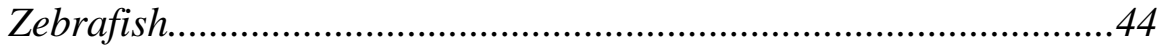

Pagothenia borchgrevinki and Trematomus bernacchii...................46

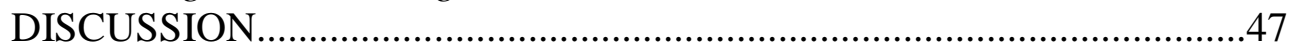

Heat-induced nuclear accumulation of C/EBP- $\delta$............................47

Potential regulatory pathways controlling $C / E B P-\delta$ expression during heat stress.........................................................................50

Heat-induced DNA damage in retinal cells.....................................53

Concluding remarks...................................................................... 54

CHAPTER 4: PROTEIN LEVELS OF PROLIFERATING CELL NUCLEAR ANTIGEN (PCNA) IN FIELD-ACCLIMATED AND HEAT-STRESSED

TREMATOMUS BERNACCHII..............................................................56

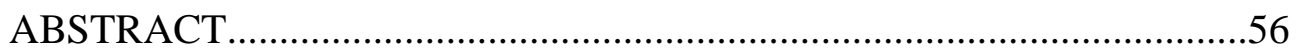

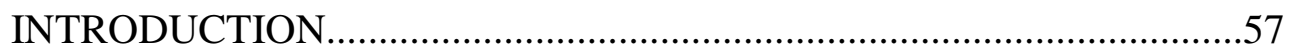

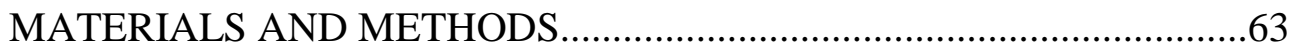

Animal collection and maintenance ..............................................63

Heat-stress treatments.................................................................64

PCNA quantification by western blot..............................................64

Data analysis and statistics..........................................................65

Relationship between PCNA and body mass..................................66

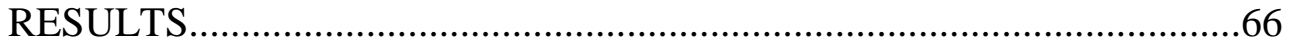

PCNA levels in field-acclimated Trematomus bernacchii...............66

PCNA levels in heat-stressed Trematomus bernacchii.....................67

Relationship between PCNA and body mass...................................69

Relationship between PCNA and C/EBP- $\delta$ concentration................70

DISCUSSION................................................................................

Constitutive levels of PCNA in field-acclimated $\mathrm{T}$. bernacchii.........71

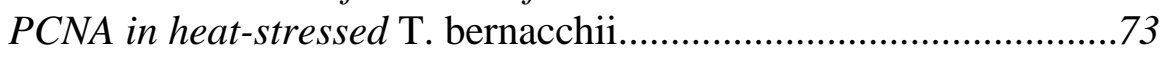

Transcriptional regulation of PCNA................................................. 75

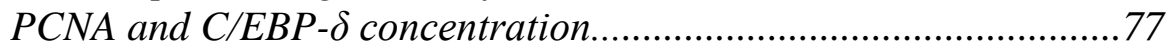

Concluding remarks...................................................................

CHAPTER 5: FLOW-CYTOMETRY ANALYSIS OF CELL CYCLE AND

APOPTOSIS IN HEAT-STRESSED TREMATOMUS BERNACCHII

HEPATOCYTES.....................................................................................................79

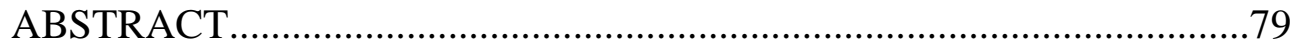

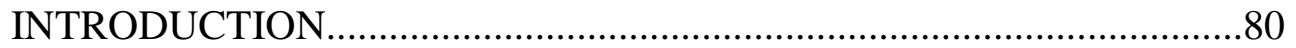

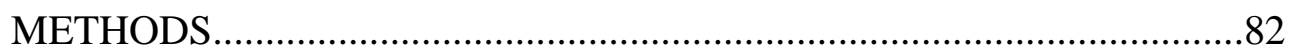

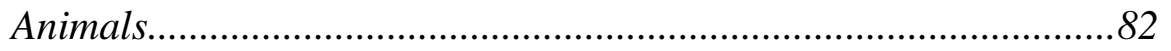

Temperature treatments..............................................................8 84

Cell cycle and TUNEL analysis by flow cytometry...........................84

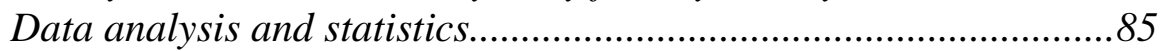

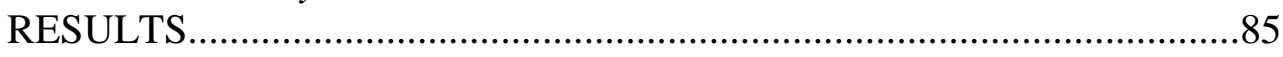




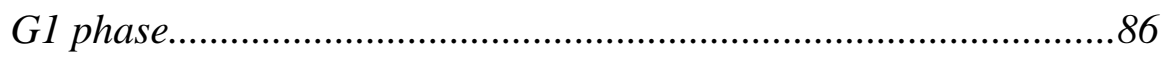

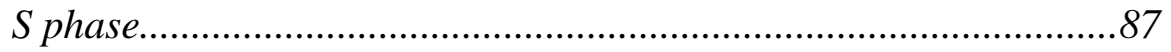

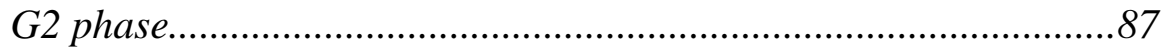

Apoptotic cells......................................................................8

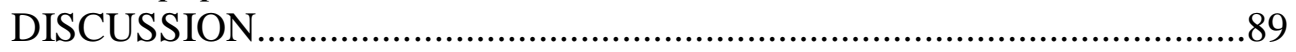

CHAPTER 6: THE NEW SYNTHESIS: A MODIFIED STRESS RESPONSE

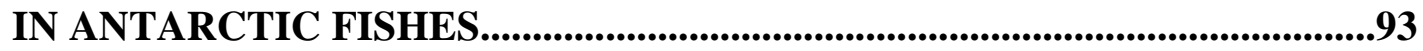

Initial hypothesis 1) Apoptosis and cell cycle arrest may be important components of the cellular stress response (CSR) in polar

organisms.............................................................................93

Initial hypothesis 2) The CCAAT/Enhancer-binding protein delta $(C / E B P-\delta)$ transcription factor is heat-inducible in Antarctic

fishes.

.96

Initial hypothesis 3) If hypotheses 1 and 2 are supported, perhaps

$C / E B P-\delta$ is correlated with cell cycle arrest in Antarctic

fishes.

The new model: sublethal and lethal heat stress responses in

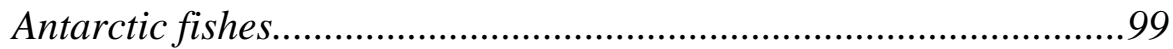

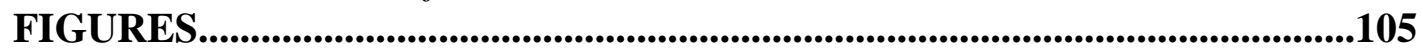

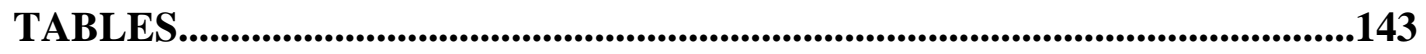

REFERENCES.......................................................................................160

APPENDIX: PRELIMINARY INVESTIGATIONS OF STAT3....................173 


\section{List of Tables}

TABLE 1. RESULTS FROM PAIRED STUDENT'S T TESTS COMPARING PCNA PROTEIN CONCENTRATION AMONG TISSUE TYPES IN SIX FIELD-ACCLIMATED TREMATOMUS BERNACCHII. . 143

TABLE 2. TWO-WAY ANOVA RESULTS FOR PCNA PROTEIN CONCENTRATION IN CONTROL $\left(-1.0 \pm 0.5^{\circ} \mathrm{C}\right)$ AND HEAT-STRESSED $\left(2.0^{\circ} \mathrm{C}\right.$ AND $\left.4.0^{\circ} \mathrm{C}\right)$ TREMATOMUS

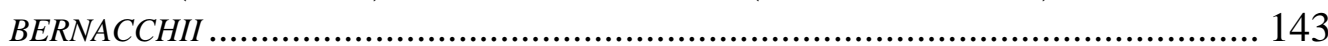




\section{List of Figures}

FIGURE 1. LENGTH VERSUS MASS PLOT FOR PAGOTHENIA BORCHGREVINKI AND TREMATOMUS BERNACCHII COLLECTED IN MCMURDO SOUND DURING THE 2010 FIELD SEASON.

FIGURE 2. MULTI-TISSUE ANALYSIS OF C/EBP- $\triangle$ PROTEIN LEVELS IN THREE FIELDCAUGHT $\left(-1.86 \pm 0.5^{\circ} \mathrm{C}\right)$, UNTREATED TREMATOMUS BERNACCHII.................... 106

Figure 3. PROTEIN LEVELS OF C/EBP- $\triangle$ IN FIELD-ACCLIMATED $(N=10)$ VS. $4.0^{\circ} \mathrm{C}$ ACCLIMATED $(N=5)$ TREMATOMUS BERNACCHII WHITE MUSCLE TISSUE.

FiguRE 4. PROTEIN LEVELS OF C/EBP- IN TREMATOMUS BERNACCHII WHITE MUSCLE TISSUE DURING $4.0^{\circ} \mathrm{C}$ HEAT SHOCK AND SUBSEQUENT RECOVERY AT $-1.0 \pm 0.5^{\circ} \mathrm{C}$

FIGURE 5. C/EBP- $\triangle$ PROTEIN LEVELS IN CONTROL AND HEAT-STRESSED TREMATOMUS BERNACCHII SPLEEN AND WHITE MUSCLE AS DETERMINED BY WESTERN BLOT 109

FIGURE 6. SPLENIC C/EBP- $\triangle$ PROTEIN CONCENTRATION AND BODY MASS FOR TREMATOMUS BERNACCHII HELD UNDER CONTROL AND HEAT-STRESS CONDITIONS FOR $72 \mathrm{H}$ OR $168 \mathrm{H}$

FIGURE 7. C/EBP- $\triangle$ PROTEIN LEVELS IN CONTROL AND HEAT-STRESSED PAGOTHENIA BORCHGREVINKI SPLEEN AS DETERMINED BY WESTERN BLOT......................... 111

FIGURE 8. EXPERIMENTAL EXPOSURE FOR HEAT-STRESSED ZEBRAFISH .................. 112

FIGURE 9. NEGATIVE CONTROL SLIDE FOR C/EBP- $\triangle$ IHC .................................. 113

FIGURE 10. POSITIVE CONTROL SLIDE FOR TUNEL IHC .................................... 114

FIGURE 11. REPRESENTATIVE MICROGRAPHS DEPICTING H\&E, C/EBP- $\triangle$ AND TUNEL STAINING OF HEAT-STRESSED $\left(35.5^{\circ} \mathrm{C}\right)$ AND CONTROL $\left(28.5^{\circ} \mathrm{C}\right)$ ZEBRAFISH RETINAE..

FIGURE 12. COLOR DECONVOLUTION OF C/EBP- $\triangle$ DAB STAIN FROM HAEMATOXYLIN COUNTERSTAIN EMPHASIZES THE NUCLEAR ACCUMULATION OF C/EBP- $\triangle$ PROTEIN IN CELL LAYERS OF THE ZEBRAFISH RETINAE.

FIGURE 13. COLOR DECONVOLUTION OF C/EBP- $\triangle$ DAB STAIN FROM HAEMATOXYLIN COUNTERSTAIN EMPHASIZES THE HEAT-INDUCED NUCLEAR ACCUMULATION OF THIS TRANSCRIPTION FACTOR IN ZEBRAFISH RETINA.

FIGURE 14. QUANTIFICATION OF C/EBP- $\triangle$ DAB STAINING OF SEPARATE RETINAL LAYERS IN HEAT-STRESSED $D$. RERIO.

FIGURE 15. REPRESENTATIVE MICROGRAPHS DEPICTING H\&E, C/EBP- $\triangle$ AND TUNEL STAINING OF WHITE MUSCLE FROM HEAT-STRESSED $\left(35.5^{\circ} \mathrm{C}\right)$ AND CONTROL $\left(28.5^{\circ} \mathrm{C}\right)$ ZEBRAFISH.

FIGURE 16. REPRESENTATIVE MICROGRAPHS DEPICTING H\&E, C/EBP- $\triangle$ AND TUNEL STAINING OF WHITE MATTER FROM HEAT-STRESSED $\left(35.5^{\circ} \mathrm{C}\right)$ AND CONTROL $\left(28.5^{\circ} \mathrm{C}\right)$ ZEBRAFISH OPTIC TECTUM...

FIGURE 17. REPRESENTATIVE COLOR DECONVOLUTION OF C/EBP- $\triangle$ DAB STAIN FROM HAEMATOXYLIN COUNTERSTAIN FOR ZEBRAFISH OPTIC TECTUM WHITE MATTER. 
FIGURE 18. COLOR DECONVOLUTION OF C/EBP- $\triangle$ DAB STAIN FROM HAEMATOXYLIN COUNTERSTAIN FOR CONTROL $\left(28.5^{\circ} \mathrm{C}\right)$ AND HEAT STRESSED $\left(35.5^{\circ} \mathrm{C}\right)$

ZEBRAFISH OPTIC TECTA. 122

FIGURE 19. REPRESENTATIVE MICROGRAPHS DEPICTING H\&E, C/EBP- $\triangle$ AND TUNEL STAINING OF HEAT-STRESSED $\left(35.5^{\circ} \mathrm{C}\right)$ AND CONTROL $\left(28.5^{\circ} \mathrm{C}\right) \mathrm{ZEBRAFISH}$ LIVERS.

FIGURE 20. COLOR DECONVOLUTION OF C/EBP- $\triangle$ DAB STAIN FROM HAEMATOXYLIN COUNTERSTAIN FOR CONTROL $\left(28.5^{\circ} \mathrm{C}\right)$ AND HEAT-STRESSED $\left(35.5^{\circ} \mathrm{C}\right)$ ZEBRAFISH LIVERS.

FIGURE 21. NUCLEAR C/EBP- $\triangle$ CONCENTRATIONS IN TREMATOMUS BERNACCHII TISSUES FOLLOWING 6 H OF HEAT STRESS. 125

FIGURE 22. NUCLEAR C/EBP-A CONCENTRATIONS IN PAGOTHENIA BORCHGREVINKI TISSUES FOLLOWING 6 H OF HEAT STRESS..

FIGURE 23. NUCLEAR C/EBP-A CONCENTRATIONS IN PAGOTHENIA BORCHGREVINKI TISSUES FOLLOWING 168 H OF HEAT STRESS..

FIGURE 24. C/EBP- $\triangle$ DAB IHC OF BRAIN TISSUE FROM PAGOTHENIA BORCHGREVINKI HELD AT $4.0^{\circ} \mathrm{C}$ AND $-1.86^{\circ} \mathrm{C}$ FOR 168 HRS (ACQUIRED AT $200 \mathrm{X}$ MAGNIFICATION). 128

FIGURE 25. C/EBP- $\triangle$ DAB IHC OF BRAIN TISSUE FROM PAGOTHENIA BORCHGREVINKI HELD AT $4.0^{\circ} \mathrm{C}$ AND $-1.86^{\circ} \mathrm{C}$ FOR 168 HRS (ACQUIRED AT 400X MAGNIFICATION).

FIGURE 26. C/EBP- $\triangle$ DAB IHC OF RETINAE FROM PAGOTHENIA BORCHGREVINKI HELD AT $4.0^{\circ} \mathrm{C}$ AND $-1.86^{\circ} \mathrm{C}$ FOR 168 HRS (ACQUIRED AT 200X MAGNIFICATION)... 130

FIGURE 27. C/EBP- $\triangle$ DAB IHC OF RETINAE FROM PAGOTHENIA BORCHGREVINKI HELD AT $4.0^{\circ} \mathrm{C}$ AND $-1.86^{\circ} \mathrm{C}$ FOR 168 HRS (ACQUIRED AT 400X MAGNIFICATION)... 131

FIGURE 28. C/EBP- $\triangle$ DAB IHC OF GILL TISSUE FROM PAGOTHENIA BORCHGREVINKI HELD AT $4.0^{\circ} \mathrm{C}$ AND $-1.86^{\circ} \mathrm{C}$ FOR 168 HRS (ACQUIRED AT $200 \mathrm{X}$ MAGNIFICATION). NOTE THE DARK STAINING OF ENDOTHELIAL CELLS, SMOOTHE MUSCLE CELLS AND CHONDROCYTES.

FIGURE 29. C/EBP- $\triangle$ DAB IHC OF GILL TISSUE FROM PAGOTHENIA BORCHGREVINKI HELD AT $4.0^{\circ} \mathrm{C}$ AND $-1.86^{\circ} \mathrm{C}$ FOR 168 HRS (ACQUIRED AT $400 \mathrm{X}$ MAGNIFICATION).

FIGURE 30. C/EBP- $\triangle$ DAB IHC OF HEART TISSUE FROM PAGOTHENIA BORCHGREVINKI HELD AT $4.0^{\circ} \mathrm{C}$ AND $-1.86^{\circ} \mathrm{C}$ FOR 168 HRS (ACQUIRED AT $200 \mathrm{X}$ MAGNIFICATION). NOTE THAT THE MIDDLE RIGHT PANEL DEPICTS A BLOOD CLOT IN LIEU OF ACTUAL CARDIAC MUSCLE TISSUE. 134

FIGURE 31. C/EBP- $\triangle$ DAB IHC OF HEART TISSUE FROM PAGOTHENIA BORCHGREVINKI HELD AT $4.0^{\circ} \mathrm{C}$ AND $-1.86^{\circ} \mathrm{C}$ FOR 168 HRS (ACQUIRED AT 400X MAGNIFICATION). NOTE THAT THE BOTTOM RIGHT PANEL DEPICTS A BLOOD CLOT IN LIEU OF ACTUAL CARDIAC MUSCLE TISSUE. 135

FIGURE 32. C/EBP- $\triangle$ DAB IHC OF LIVER TISSUE FROM PAGOTHENIA BORCHGREVINKI HELD AT $4.0^{\circ} \mathrm{C}$ AND $-1.86^{\circ} \mathrm{C}$ FOR 168 HRS (ACQUIRED AT $200 \mathrm{X}$ MAGNIFICATION). 136 
Figure 33. C/EBP- $\triangle$ DAB IHC OF LIVER TISSUE FROM PAGOTHENIA BORCHGREVINKI HELD AT $4.0^{\circ} \mathrm{C}$ AND $-1.86^{\circ} \mathrm{C}$ FOR 168 HRS (ACQUIRED AT 400X

MAGNIFICATION).

FIGURE 34. C/EBP- $\triangle$ DAB IHC OF SPLEEN TISSUE FROM PAGOTHENIA BORCHGREVINKI HELD AT $4.0^{\circ} \mathrm{C}$ AND $-1.86^{\circ} \mathrm{C}$ FOR 168 HRS (ACQUIRED AT 200X MAGNIFICATION). 138

FIGURE 35. C/EBP- $\triangle$ DAB IHC OF SPLEEN TISSUE FROM PAGOTHENIA BORCHGREVINKI HELD AT $4.0^{\circ} \mathrm{C}$ AND $-1.86^{\circ} \mathrm{C}$ FOR 168 HRS (ACQUIRED AT 400X MAGNIFICATION).

FIGURE 36. C/EBP- $\triangle$ DAB IHC OF WHITE MUSCLE TISSUE FROM PAGOTHENIA BORCHGREVINKI HELD AT $4.0^{\circ} \mathrm{C}$ AND $-1.86^{\circ} \mathrm{C}$ FOR 168 HRS (ACQUIRED AT $200 \mathrm{X}$ MAGNIFICATION).

FIGURE 37. C/EBP- $\triangle$ DAB IHC OF WHITE MUSCLE TISSUE FROM PAGOTHENIA BORCHGREVINKI HELD AT $4.0^{\circ} \mathrm{C}$ AND $-1.86^{\circ} \mathrm{C}$ FOR 168 HRS (ACQUIRED AT 400X MAGNIFICATION).

FIGURE 38. MULTI-TISSUE PCNA PROTEIN LEVELS IN SIX FIELD-ACCLIMATED

TREMATOMUS BERNACCHII .

FIGURE 39. PCNA PROTEIN CONCENTRATIONS IN CONTROL $\left(-1.0 \pm 0.5^{\circ} \mathrm{C}\right)$ AND HEATSTRESSED $\left(2.0^{\circ} \mathrm{C}\right.$ AND $\left.4.0^{\circ} \mathrm{C}\right)$ TREMATOMUS BERNACCHII HEART.. 144

FIGURE 40. PCNA PROTEIN CONCENTRATIONS IN CONTROL $\left(-1.0 \pm 0.5^{\circ} \mathrm{C}\right)$ AND HEATSTRESSED $\left(2.0^{\circ} \mathrm{C}\right.$ AND $\left.4.0^{\circ} \mathrm{C}\right)$ TREMATOMUS BERNACCHII LIVER. 145

FIGURE 41. PCNA PROTEIN CONCENTRATIONS IN CONTROL $\left(-1.0 \pm 0.5^{\circ} \mathrm{C}\right)$ AND HEATSTRESSED $\left(2.0^{\circ} \mathrm{C}\right.$ AND $\left.4.0^{\circ} \mathrm{C}\right)$ TREMATOMUS BERNACCHII GILL.

FIGURE 42. PCNA PROTEIN CONCENTRATIONS IN CONTROL $\left(-1.0 \pm 0.5^{\circ} \mathrm{C}\right)$ AND HEAT-

STRESSED $\left(2.0^{\circ} \mathrm{C}\right.$ AND $\left.4.0^{\circ} \mathrm{C}\right)$ TREMATOMUS BERNACCHII SPLEEN.

FIGURE 43. PCNA PROTEIN CONCENTRATION VERSUS BODY MASS FOR SIX

TREMATOMUS BERNACCHII HELD AT $-1.0 \pm 0.5^{\circ} \mathrm{C}$ FOR 72 OR $168 \mathrm{H}$. 148

FIGURE 44. PCNA PROTEIN CONCENTRATION VERSUS BODY MASS FOR SIX TREMATOMUS BERNACCHII HELD AT $2.0^{\circ} \mathrm{C}$ FOR 72 OR $168 \mathrm{H}$.

FIGURE 45. PCNA PROTEIN CONCENTRATION VERSUS BODY MASS FOR SIX

TREMATOMUS BERNACCHII HELD AT $4.0^{\circ} \mathrm{C}$ FOR 72 OR $168 \mathrm{H}$ 150

FIGURE 46. COMPARISON OF C/EBP- $\delta$ AND PCNA PROTEIN CONCENTRATIONS IN SPLEEN FROM CONTROL TREMATOMUS BERNACCHII HELD AT $-1.0 \pm 0.5^{\circ} \mathrm{C}$ FOR UP TO $168 \mathrm{H}(\mathrm{N}=12)$..

FIGURE 47. COMPARISON OF C/EBP- $\delta$ AND PCNA PROTEIN CONCENTRATION IN SPLEEN FROM CONTROL AND HEAT-STRESSED TREMATOMUS BERNACCHII SAMPLED AT 6, 24, 72 OR $168 \mathrm{H}$.

FIGURE 48. REPRESENTATIVE FLOW CYTOMETRY DATA SHOWING DNA CONTENT OF TREMATOMUS BERNACCHII HEPATOCYTES HELD AT $0.0^{\circ} \mathrm{C}$ OR $10.0^{\circ} \mathrm{C}$ FOR UP TO 24 H.

FIGURE 49. CELL CYCLE ANALYSIS OF TREMATOMUS BERNACCHII HEPATOCYTES HELD AT $-2,0,2,6$ AND $10^{\circ} \mathrm{C}$ FOR UP TO $24 \mathrm{H}$. 154 
FigURE 50. ANTI-STAT3 IMMUNOBLOT OF TREMATOMUS BERNACCHII WHITE MUSCLE TISSUE DURING $4.0^{\circ} \mathrm{C}$ HEAT SHOCK AND SUBSEQUENT RECOVERY AT -

$1.0 \pm 0.5^{\circ} \mathrm{C}$ 155

FigURE 51. ANTI-STAT3 IMMUNOBLOTS FOR RATTUS NORVEGICUS CELL LINE PC-12 AT CONTROL $\left(37^{\circ} \mathrm{C}\right)$ AND HEAT SHOCK $\left(2 \mathrm{H} \mathrm{AT} 44^{\circ} \mathrm{C}\right.$ FOLLOWED BY 5-18 H RECOVERY AT $37^{\circ} \mathrm{C}$ ). 156

FIGURE 52. MULTI-ORGANISM COMPARISON OF STAT3, PSTAT3 AND RELATED

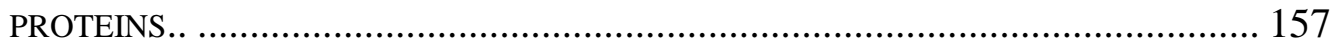

FigURE 53. ANTI-PSTAT3 IMMUNOBLOT OF RATTUS NORVEGICUS CELL LINE PC-12 AND TREMATOMUS BERNACCHII WHITE MUSCLE TISSUE AT CONTROL $\left(37^{\circ} \mathrm{C}\right.$ OR $\left.1.86^{\circ} \mathrm{C}\right)$ AND HEAT SHOCK $\left(44^{\circ} \mathrm{C}\right.$ OR $\left.4^{\circ} \mathrm{C}\right)$ 159 


\section{List of Abbreviations}

C/EBP(- $\delta)$

CA

cAMP

CSR

$\mathrm{DAB}$

Epi

GADD45

GCN

GM-STAT3
CCAAT/enhancer-binding protein(-delta)

catecholamines

cyclic adenosine monophosphate

cellular stress response

3,3'-diaminobenzidine

epinephrine

growth arrest and DNA damage inducible protein 45

ganglion cell nuclei

Gillichthys mirabilis signal transducer and activator of

transcription 3

heat shock proteins

HSR

heat shock response

IHC

INL

IPL immunohistochemistry

inner nuclear layer inner plexiform layer 


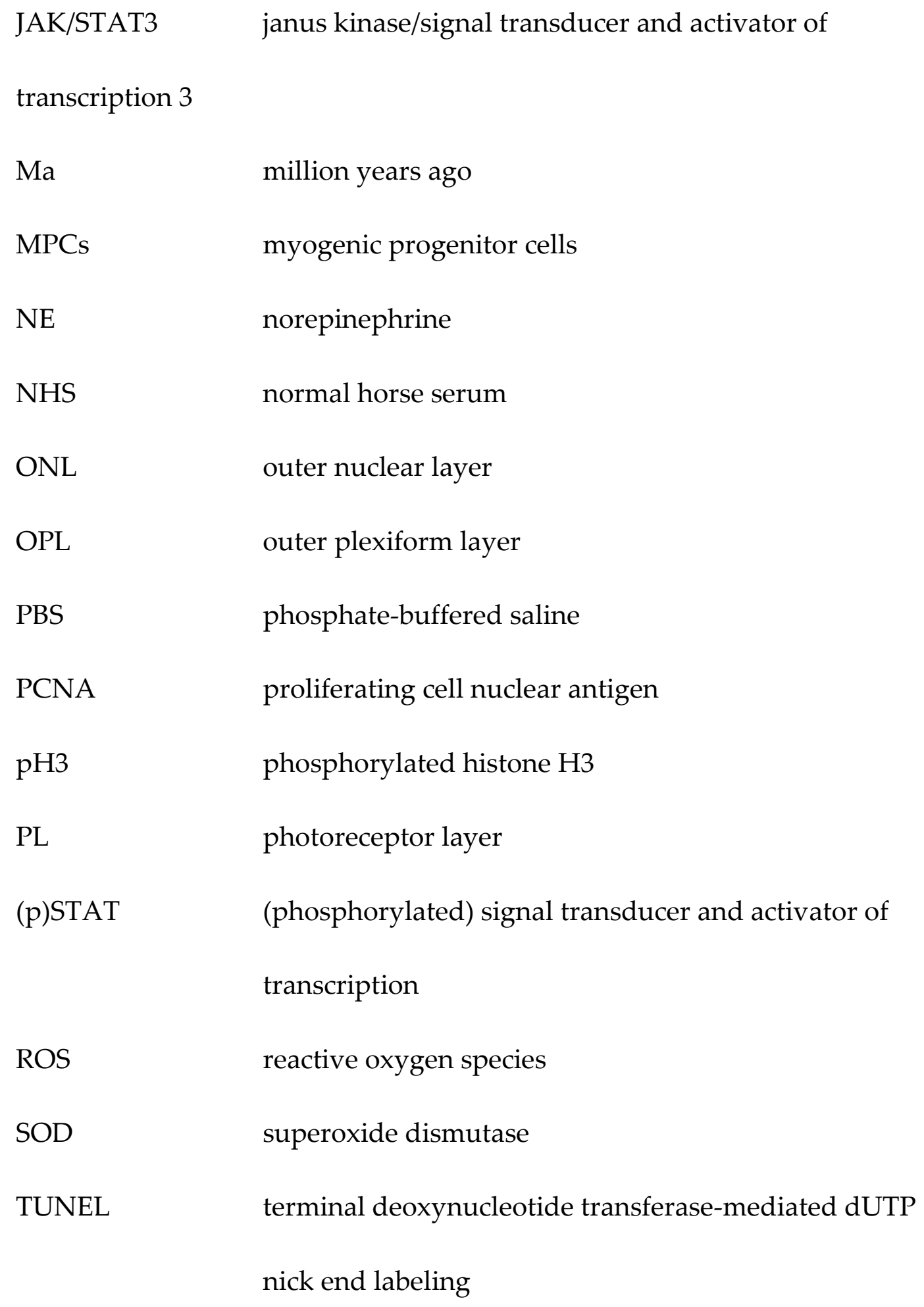




\section{Chapter 1: Introduction}

\section{Antarctic fishes: evolution in the cold}

250 million years ago (Ma), all of Earth's land mass was concentrated into the supercontinent Pangaea and surrounded by the world ocean Panthalassa. The breaking apart of Pangaea into the seven modern continents was an incremental process involving the formation of several intermediate land masses, the largest of which were Laurasia and Gondwana. Gondwana was situated in the Southern Hemisphere and comprised the modern-day continents of Antarctica, Australia, India, Africa and South America. Antarctica occupied a central portion of Gondwana and had by the Cretaceous period drifted to the South Pole. Perhaps surprisingly, it became neither cold nor climatically isolated until relatively recently in geologic time. Once Africa and the Indian Shield had separated from the rest of the subcontinent, an ocean formed between East Antarctica and Australia (ca. $50 \mathrm{Ma}$ ), and separation rates between Antarctica and South America increased drastically (Livermore et al., 2005). A deep-water connection called the Drake Passage was formed between Antarctica and the southernmost tip of South America 
34-30 Ma, leading to the establishment of a tremendous circumpolar current and subsequent rapid cooling and glaciation of Antarctica (Livermore et al., 2005). Today this is the most voluminous ocean current in existence. The continent's current state of extreme and stable cold accompanied by immense ice presence was reached approximately $14-11 \mathrm{Ma}$, during the middle Miocene (Kennett, 1977). Vast temperate forests, home to a great diversity of organisms, were covered with a blanket of ice some two miles thick. Almost the entire fossil record lies locked away, but scattered dinosaur skeletons and hardwood trees speak to Antarctica's warmer, livelier past.

Much of the cosmopolitan ichthyofauna present during the Eocene seems to have vanished as a result of decreased ocean temperatures and increased presence of ice. The benthic species that remained underwent an adaptive radiation similar to freshwater species flocks like that of the East African cichilids (Eastman, 1993; Eastman and McCune, 2000). The notothenioids are the only example of a marine piscine species flock. A benthic ancestor with no swim bladder evolved neutral buoyancy and radiated to fill a variety of niches in the water column. Although the fossil history of Antarctic fishes is minimal, the modern fauna is reasonably wellknown (Eastman, 2005). The Southern Ocean makes up 10\% of the world's 
oceans but contains only $1.2 \%$ of the world's fish species diversity. The perciform suborder notothenioidei includes 101 Antarctic species and makes up $45 \%$ of the benthic species diversity in the region. At the highest latitudes, an impressive $91 \%$ of all biomass is notothenioid fishes. Marine species living near the continent have evolved at or near the freezing point of seawater ($1.86^{\circ} \mathrm{C}$ ) for at least 14 million years and thus provide us with a unique system in which to study evolution in an extremely cold and stable environment.

To cope with the cold and presence of ice, Antarctic fishes possess numerous biochemical adaptations (Coppes Petricorena and Somero, 2007). These include antifreeze glycoproteins, enzymes with higher catalytic efficiencies ( $\left.\mathrm{K}_{\mathrm{cat}}\right)$, cytoskeletal elements capable of polymerization at low temperatures, and a reduced reliance on oxygen-carrying haemoproteins in the blood and muscle (DeVries, 1971; Fields and Somero, 1998; Detrich et al., 2000; Sidell and O'Brien, 2006). A crucial consequence of this extensive cold adaptation is the extreme stenothermality of these fishes (upper-lethal temperature of $6^{\circ} \mathrm{C}$; Somero and DeVries, 1967). It must be stated that temperature effects are not only relevant at the biochemical level. An organism's thermal environment affects all levels of biological organization, from molecules to populations (e.g., Pörtner et al., 2007). 


\section{The cellular stress response}

Organisms respond to environmental insult by mounting a taxonomically well conserved cellular stress response (CSR; Kültz, 2005). The CSR is generally not stressor-specific. It is a suite of biochemical mechanisms initiated in response to macromolecular damage caused by osmotic stress, thermal stress, heavy metal stress, ionizing radiation, baric stress, oxidative stress and hypoxia/ischemia (Hochachka and Somero, 2002). The four major aspects of the CSR are (i) repair and stabilization of macromolecules, (ii) metabolic adjustment, (iii) cell-cycle checkpoint control and (iv) apoptosis. Owing to the recent popularity of functional and comparative genomics, I now understand that these four broad mechanisms involve the differential regulation of hundreds of genes, many of which are structurally conserved across taxa.

By identifying those transcripts whose concentrations increase or decrease in response to environmental stress, recent cDNA microarray studies have provided an excellent jumping-off point for investigations into the CSR. Researchers may now build upon mRNA-level data in order to delineate the precise molecular mechanisms governing the CSR. In fishes, researchers have used this high-throughput technique to elucidate the transcriptomic changes 
accompanying hypoxia (Gracey et al., 2001), cold acclimation (Gracey et al., 2004; Malek et al., 2004; Vornanen et al., 2005; Castilho et al., 2009) and heat stress (Podrabsky and Somero, 2004, Buckley et al., 2006; Kassahn et al., 2007; Buckley and Somero, 2009). Apart from transcriptomics, however, relatively little is known about the regulation and functioning of these gene products in times of stress. That is to say that mRNA processing and nuclear export, translational regulation, subcellular protein localization, posttranslational modification and protein-protein interactions remain rather mysterious when it comes to the CSR, with the notable exception of heat shock proteins (Hsps).

One of the most famous and well-described aspects of the CSR is the classical heat shock response (HSR), historically defined as the ability to upregulate the production of Hsps in response to proteotoxic stress (Lindquist, 1986; Feder and Hofmann, 1999). Heat shock proteins function as molecular chaperones by helping misfolded proteins resume their functional conformations and by preventing the formation of harmful protein aggregates (Fink, 1999). The HSR has been detected in virtually every organism studied, with some rare and notable exceptions including Hydra oligactis (Bosch et al., 1988) and Antarctic notothenioid fishes (Buckley and Somero, 2009; Hofmann et al., 2000). In the case of the latter, several studies suggest that although an 
inducible HSR is absent, constitutive expression of what are normally inducible forms of Hsp indicates an increased need for molecular chaperoning in the extreme cold (Buckley et al., 2004; Place and Hofmann, 2004; Place et al., 2004; Chen et al., 2008). Using heterologous hybridization to a Gillichthys mirabilis microarray, a recent cDNA study identified hundreds of heatresponsive genes in the cold-adapted Antarctic notothenioid Trematomus bernacchii, revealing that even though these fish lack a so-called HSR, they are still able to respond to heat stress at the cellular level (Buckley and Somero, 2009). Investigators may benefit from revising the strict and oftentimes misleading term, "the heat shock response." The heat-sensitive genes in $T$. bernacchii are associated with diverse cellular processes including, but not limited to, intracellular signaling, protein biosynthesis, carbohydrate metabolism, transcriptional regulation, and cytoskeletal organization. Results from the present study add to a growing body of data that documents a unique but presumably effective CSR in these animals.

Of particular interest is the transcription factor CCAAT/enhancerbinding protein delta (C/EBP- $\delta)$, whose mRNA and protein levels are heat responsive in fishes including T. bernacchii. C/EBP- $\delta$ is a eukaryotic transcription factor and putative tumor suppressor that is closely associated 
with apoptosis and exit from the cell cycle. These processes are understudied in the context of the CSR. The observation that this gene product is upregulated in response to heat stress in several ectotherms supports the hypothesis that during bouts of environmental stress, increased protein concentration of C/EBP- $\delta$ effects a halt on cell division, thereby allowing cells to direct more energy towards cytoprotection (Buckley, 2011). In other cellular contexts, the induction of C/EBP- $\delta$ may be pro-apoptotic (Thangaraju et al., 2005), so it is possible that the heat-induction of C/EBP- $\delta$ may also reflect the initiation of programmed cell death in response to irreversible damage to DNA or other critical cellular components. This dissertation explores the role that C/EBP- $\delta$ may play in coordinating the CSR in the cold-adapted Antarctic fishes Trematomus bernacchii and Pagothenia borchrevinki as well as the tropical freshwater stenotherm and model species Danio rerio.

\section{CCAAT/enhancer-binding proteins}

The CCAAT/enhancer-binding protein (C/EBP) family of transcription factors comprises several gene regulatory proteins implicated in a variety of normal processes (e.g., adipocyte differentiation, erythropoiesis, memory) and 
pathophysiological conditions (e.g., liver regeneration, cancer, inflammation; Lekstrom-Himes and Xanthopoulos, 1998; Ramji and Foka, 2002). C/EBPs have recently been recognized as a paradigm for the interaction between gene expression and proliferation control (Nerlov, 2007). One isoform, C/EBP- $\delta$, is under-expressed in human breast cancer cells (Porter et al., 2001; Porter et al., 2003), and the forced expression of C/EBP- $\delta$ in prostate cancer and breast cancer cell lines dramatically reduces clonal growth (Ikezoe et al., 2005). Furthermore, C/EBP- $\delta$ is silenced by methylation in acute myeloid leukemia (Agrawal, 2007). Together, these results make a convincing case for the role of C/EBP- $\delta$ as a brake on cell division, a so-called "molecular stop sign" (Johnson, 2005).

Not surprisingly, the majority of C/EBP research to date has focused on biomedical applications using mammalian study systems. However, C/EBPs are gaining attention as stress-responsive proteins in aquatic ectotherms. Levels of C/EBP- $\delta$ mRNA increase in response to heat stress in the eurytolerant estuarine goby Gillichthys mirabilis, a popular "non-model model species" for ecophysiologists (Buckley et al., 2006). C/EBP-delta transcripts are also heat-inducible in the Antarctic notothenioid Trematomus bernacchii (Buckley and Somero, 2009). In the case of the former, C/EBP- $\delta$ protein 
concentrations also increase with heat stress (Buckley, 2011). Cardiac ventricle from bluefin tuna (Thunnus orientalis) acclimated at $20^{\circ} \mathrm{C}$ when compared to specimens held at $15^{\circ} \mathrm{C}$ possess elevated mRNA levels of C/EBP- $\delta$ and decreased levels of $\mathrm{C} / \mathrm{EBP}-\zeta$, a truncated family member that inhibits the activity of other C/EBPs by forming heterodimers with them (Ramji and Foka, 2002; Castilho et al., 2009). In the coral reef fish Pomacentrus moluccensis, heat stress causes a down-regulation of C/EBP- $\delta$ (Kassahn et al., 2007), suggesting that heat induction of this transcription factor is not common to all fishes. In G. mirabilis subjected to hyperosmotic stress, C/EBP- $\delta$ displayed the highest fold change of any transcript (Evans and Somero, 2008), underlining the fact that $\mathrm{C} / \mathrm{EBP}-\delta$ is responsive to other forms of environmental stress besides thermal insult. Data mining revealed that oxidative stress also leads to an increase in C/EBP- $\delta$ levels in G. mirabilis, though the 1.7-fold increase did not meet the statistical cut-off for publication (Gracey et al., 2001; Buckley, personal communication). It is therefore important to note that for cDNA microarray studies, missing data may not always equate to a lack of physiologically important changes in gene expression.

Other C/EBP transcription factors besides C/EBP- $\delta$ appear to be important during stress in aquatic ectotherms. C/EBP- $\beta$, which has both pro- 
and anti-proliferative roles, as well as roles in inflammation and immunity, is heat-inducible in T. bernacchii (Buckley and Somero, 2009). During coldacclimation of common carp, mRNA levels of C/EBP- $\beta$ and C/EBP- $\alpha$ decrease in a tissue-specific manner (Gracey et al., 2004). C/EBP- $\beta$ is one of the most strongly induced transcripts in salmon skin in response to infection by the salmon louse Lepeophtheirus salmonis, a marine ectoparasitic caligid crustacean (Skugor et al., 2008). In the temperate sea anemone Anthopleura elegantissima, $\mathrm{C} / \mathrm{EBP}-\beta$ is upregulated in response to heat stress, down-regulated in response to UV stress, and levels of the potent tumor suppressor C/EBP- $\alpha$ decrease with heat stress (Richier et al., 2008). Similarly, the Caribbean coral Montastraea faveolata displayed a down-regulation of C/EBP- $\beta$ in response to heat stress and bleaching (Desalvo et al., 2008). These data allude to potential differences in C/EBP expression patterns between vertebrates and invertebrates. More importantly, however, these studies indicate that C/EBPs respond to a variety of stresses in a wide variety of taxa.

T. bernacchii may undergo adaptive, heat-induced cell cycle arrest, allowing cells to devote their energy to protective functions and then resume cell proliferation upon return to non-stressful environmental conditions. When damage is irreversible, cells may resort to apoptosis. In G. mirabilis and 
T. bernacchii, the heat-sensitive genes associated with cell cycle and apoptosis include C/EBP- $\delta$, C/EBP- $\beta$, GADD45, caspase-3 precursor, Bcl-2-like protein, Ras-R2, p21-RAC3, and 14-3-3 epsilon (Buckley et al., 2006; Buckley and Somero, 2009). The putative role of C/EBP- $\delta$ as a stress-inducible brake on cell division is of considerable interest in the field of ecophysiology, especially in organisms which lack the ability to upregulate Hsps. To further investigate the role this transcription factor may play in coordinating the CSR in cold-adapted stenotherms, I first examined the tissue-specific expression of C/EBP- $\delta$ in the Antarctic fishes T. bernacchii and P. borchgrevinki under normal conditions and in response to acute but sublethal heat shock (Chapter 2). In the case of $T$. bernacchii, I also measured protein levels of this transcription factor following long-term acclimation at $4.0^{\circ} \mathrm{C}$. Subcellular localization of this transcription factor was studied by DAB immunohistochemistry in these fishes as well as the tropical freshwater stenotherm Danio rerio (Chapter 3). Protein levels of proliferating cell nuclear antigen (PCNA), an established marker of cell cycle progression and critical player in DNA repair pathways, were determined in field-acclimated and heat-stressed T. bernacchii (Chapter 4). I used flow cytometry to investigate cell cycle progression and apoptosis in isolated, heatstressed hepatocytes from T. bernacchii and Pagothenia borchgrevinki (Chapter 
5). Finally, protein-level analysis of signal transducer and activator of transcription 3 (Stat3), an important upstream regulator of C/EBP-delta, was conducted in several fishes (Appendix A). A new integrated model for cellular stress response in Antarctic fishes is provided in chapter 6. 


\title{
Chapter 2: C/EBP- $\delta$ protein levels in heat-stressed Trematomus bernacchii and Pagothenia borchgrevinki
}

\author{
Abstract \\ Notothenioids dominate the Antarctic ichthyofauna, which for millions \\ of years has evolved in a thermally stable environment near the freezing point \\ of seawater $\left(-1.86^{\circ} \mathrm{C}\right)$. These species are extreme stenotherms and at least some \\ have lost the ability to upregulate heat shock proteins during exposure to \\ thermal stress. A recent cDNA microarray study revealed the capacity to \\ mount a broad-scale genomic response to heat in the common notothenioid \\ Trematomus bernacchii. Two of the heat-sensitive genes identified were of the \\ CCAAT/enhancer-binding protein (C/EBP) family of transcription factors. One \\ of these, $C / E B P-\delta$, mediates inflammatory and pro-apoptotic processes, \\ though it is best known for functioning as a brake on cell division. Because \\ apoptosis and cell cycle arrest are two understudied facets of the cellular \\ stress response, I used western blotting to examine C/EBP- $\delta$ expression in $T$. \\ bernacchii under normal and heat-stressed conditions. A highly tissue-specific \\ pattern of constitutive levels of C/EBP- $\delta$ was detected in field-acclimated \\ individuals. Highest levels were found in white muscle followed by spleen,
}


brain and gill. C/EBP- $\delta$ was not detected in heart or liver. Individuals acclimated for one month at $4.0^{\circ} \mathrm{C}$ possessed more C/EBP- $\delta$ in their white muscle compared to field-acclimated fish. Acute heat stress of $2.0^{\circ} \mathrm{C}$ or $4.0^{\circ} \mathrm{C}$ caused a transient increase in white muscle C/EBP- $\delta$ after $6 \mathrm{~h}$ when compared to controls $\left(-1.0 \pm 0.5^{\circ} \mathrm{C}\right)$. This up-regulation appears to be reversible upon return to non-stressful conditions. I posit that in unstressed T. bernacchii $\mathrm{C} / \mathrm{EBP}-\delta$ performs housekeeping functions and that it mediates inflammation, apoptosis and/or cell-cycle arrest in response to sub-lethal heat stress. Time had a significant effect on C/EBP-8 levels in Pagothenia borchgrevinki spleen, suggesting that tank effects should be taken into consideration for future studies.

\section{Introduction}

The opening of the Drake Passage in the early Cenozoic led to the establishment of the Antarctic Circumpolar Current and the subsequent isolation and rapid cooling of the Southern Ocean (Kennett, 1977; Zachos et al., 2001; DeConto and Pollard, 2003; Shevenell et al., 2004). During this period of intense climatic shift, many organisms went extinct or migrated to warmer 
environments, but some taxa including the Notothenioid fishes persisted and have evolved at near-freezing temperatures for at least the past 14 million years (Eastman, 1993; Eastman and McCune, 2000; Matschiner et al., 2011; Rutschmann et al., 2011). The successful transition of this fish fauna to the modern Antarctic ecosystem was due in large part to a suite of biochemical adaptations to the extreme cold and to the presence of ice (Coppes Petricorena and Somero, 2007; Matschiner et al., 2011). These include antifreeze glycoproteins (DeVries 1971), enzymes with higher catalytic efficiencies (Fields and Somero, 1998), cytoskeletal elements capable of polymerization at low temperatures (Detrich et al., 2000) and, in some species, a reduced reliance on oxygen-carrying haemoproteins in the blood and muscle (Sidell and O'Brien, 2006). Evolution in the stable cold may have had an associated cost, as evidenced by the extreme stenothermality of these fishes (Somero and DeVries, 1967; Somero, 2010). Furthermore, some of these species appear to have lost otherwise well-conserved physiological features, most notably the heat shock response (HSR), defined as the ability to upregulate the production of heat shock proteins (Hsps) in response to elevated temperature (Hofmann et al., 2000; Buckley et al., 2004; Buckley and Somero, 2009), a condition that may make them particularly susceptible to rising global temperatures. 
Here, I focus on a novel cellular response to elevated environmental temperature in a species of common Antarctic notothenioid fish, Trematomus bernacchii. Specifically I investigated the effect of heat stress on the expression of a regulator of cell cycle arrest and/or apoptosis, the transcription factor CCAAT/enhancer-binding protein $\delta(C / E B P-\delta)$. The CCAAT/enhancer-binding proteins (C/EBPs) are a family of six eukaryotic transcription factors $(-\alpha,-\beta,-\gamma$, $-\delta,-\varepsilon,-\zeta)$ with various roles in both normal and pathogenic processes including adipocyte differentiation, hematopoiesis, liver regeneration, memory consolidation, inflammation and cancer (Darlington et al., 1998; Diehl 1998; Lekstrom-Himes and Xanthopoulos, 1998; Poli, 1998; Lane et al., 1999; Pabst et al., 2001; Ramji and Foka, 2002; Nerlov, 2007; Moore et al., 2012). Structurally, the C/EBPs consist of a leucine zipper, a basic DNA-binding region and a transactivation domain - with the exception of $\mathrm{C} / \mathrm{EBP}-\zeta$, which lacks a transactivation domain and thus acts as a negative regulator by forming heterodimers with other C/EBPs (Ramji and Foka, 2002 and references therein). The family is regulated in an isoform-specific manner (Tsukada et al., 2011). A recent study in my lab recently demonstrated the heat-induction of one isoform, C/EBP- $\delta$, in the gill, white muscle and liver of the goby Gillichthys mirabilis (Buckley et al., 2006; Buckley, 2011). C/EBP-ס 
mediates inflammatory and pro-apoptotic processes (e.g., Poli, 1998;

Thangaraju et al., 2005; Moore et al., 2012), though it is best known for functioning as a "brake" on cell division (Johnson, 2005). This isoform is generally considered to be stress-inducible, but constitutive expression is observed in some tissue types (Buckley, 2011). The under-expression of C/EBP- $\delta$ has been described in acute myeloid leukemia and certain breast cancers (Porter et al., 2001; Porter et al., 2003), and forced expression of C/EBP$\delta$ dramatically reduces clonal growth in prostate and breast cancer cell lines (Ikezoe et al., 2005). A study by Huang et al. (2004) further supports a tumor suppressor role for C/EBP- $\delta$ by demonstrating that the loss of this transcription factor can cause transformed features and chromosomal instability.

Recent cDNA microarray studies have demonstrated heat sensitivities for C/EBP transcription factors in a variety of aquatic poikilotherms, including teleost fishes, anthozoans and a bivalve mollusc (Buckley et al., 2006; Kassahn et al., 2007; Desalvo et al., 2008; Gracey et al., 2008; Richier et al., 2008; Buckley and Somero, 2009; Castilho et al., 2009). Given that C/EBP- $\delta$ protein concentration increases in response to acute heat stress and thermal acclimation (Buckley, 2011), I hypothesize that heat-induction of C/EBP- $\delta$ in 
aquatic poikilotherms may effect a transient and adaptive cessation of the cell cycle, during which cells may focus their energy away from proliferation and towards cytoprotective functions. In keeping with its various function in mammalian models, it is possible that it may also mediate inflammatory or apoptotic pathways. Here I further investigate the stress-responsiveness of this transcriptional regulator in a multi-tissue, protein-level analysis of C/EBP$\delta$ expression in the extremely cold-adapted Antarctic fish T. bernacchii under field-caught conditions and in response to acute and chronic thermal exposure. Pagothenia borchgrevinki, a closely related cryopelagic species, is also examined.

\section{Materials and Methods}

\section{Animal collection}

Specimens of T. bernacchii (Boulenger) and Pagothenia borchgrevinki

(Boulenger) were collected from McMurdo Sound, Ross Island, Antarctica (77

$\left.53^{\prime} \mathrm{S}, 166^{\circ} 40^{\prime} \mathrm{W}\right)$, by hook-and-line through holes drilled in the sea ice during

October and November, 2005 and 2010. A fishing report was published by

Buckley (2013), and length/mass data are presented in figure 1. Ten field- 
acclimated individuals of T. bernacchii were sacrificed immediately upon capture by cervical transection. Brain, gill, heart, liver, spleen and white muscle tissue were removed on site and flash-frozen in liquid nitrogen. Animals for use in heat-stress experiments were transported in aerated coolers to flow-through seawater tanks in the aquarium facilities of Crary Laboratory, maintained by the United States Antarctic Program at McMurdo Station. Fish were held at ambient temperature $\left(-1.0 \pm 0.5^{\circ} \mathrm{C}\right)$ for $48 \mathrm{~h}$ and starved prior to use in experiments. While water temperatures in McMurdo Sound are at or slightly above the freezing point of seawater $\left(-1.86^{\circ} \mathrm{C}\right)$, transit through pipes to the holding tanks at Crary generally results in slightly higher temperatures which are nevertheless quite stable $\left(-1.0 \pm 0.5^{\circ} \mathrm{C}\right)$.

Short-course heat shock with recovery T. bernacchii were transferred to separate re-circulating seawater aquaria with a water temperature of $4.0^{\circ} \mathrm{C}$, and $n=3$ individuals were sacrificed at 0 (control), 2, 4 and $6 \mathrm{~h}$. Eight fish were then returned to ambient temperature $\left(-1.0 \pm 0.5^{\circ} \mathrm{C}\right)$ for recovery. Three individuals were sacrificed at 2 and $4 \mathrm{~h}$, and two individuals were sacrificed at $24 \mathrm{~h}$. Following sacrifice by 
cervical transection, tissues were removed and flash frozen in liquid $\mathrm{N}_{2}$ for later analysis.

\section{Long-course heat shock}

Specimens of T. bernacchii and P. borchgrevinki were transferred to two re-circulating seawater aquaria maintained at $2.0^{\circ} \mathrm{C}$ or $4.0^{\circ} \mathrm{C}$. A third group of animals remained in a flow-through seawater aquarium at ambient temperature $\left(-1.0 \pm 0.5^{\circ} \mathrm{C}\right)$ to determine whether there was variation in $\mathrm{C} / \mathrm{EBP}-\delta$ during the week-long timecourse even at ambient temperatures. Partial water changes were performed daily throughout the experiment. Three control animals were sampled at $0 \mathrm{~h}$, and $n=3$ individuals from each temperature treatment $\left(-1.0^{\circ} \mathrm{C}, 2.0^{\circ} \mathrm{C}, 4.0^{\circ} \mathrm{C}\right)$ were sacrificed by cervical transection at 6,24 , 72 and $168 \mathrm{~h}$, their tissues removed and flash-frozen in liquid nitrogen.

\section{Long-term heat acclimation}

Five $T$. bernacchii were held in a re-circulating seawater aquarium maintained at $4.0^{\circ} \mathrm{C}$ for a period of one month, during which they were fed $T$. bernacchii white muscle tissue every other day. At the end of the experiment, fish were sacrificed by cervical transection, and their tissues were removed and frozen in liquid $\mathrm{N}_{2}$. 


\section{Protein quantification via western blotting}

Tissue samples were homogenized in lysis buffer $\left(32 \mathrm{mmol}^{-1} \mathrm{Tris}-\mathrm{Cl}, \mathrm{pH}\right.$ $6.8,0.2 \%$ sodium dodecyl sulfate), boiled for $5 \mathrm{~min}$ at $100^{\circ} \mathrm{C}$, and centrifuged at $12,000 \times \mathrm{g}$ at room temperature $\left(\sim 20^{\circ} \mathrm{C} ; \mathrm{RT}\right)$. Supernatants were collected for use in the following analyses. Protein concentrations were determined by Bradford assay (Pierce, Rockford, IL, USA). Ten $\mu$ g of total protein were separated via polyacrylamide gel electrophoresis and transferred to nitrocellulose membranes via overnight electrotransfer at 30V. Blots were blocked for $1 \mathrm{~h}$ at $\mathrm{RT}$ in $1 \times \mathrm{PBS}+5 \%$ non-fat dry milk (NFDM) under constant shaking. Primary incubations were performed at an antibody concentration of 1:1000 in $1 \times$ PBS $+5 \%$ NFDM for $1.5 \mathrm{~h}$ at RT under constant shaking. This step utilized a custom rabbit IgG antibody (Affinity BioReagents, Rockford, IL, USA) raised against a 15 amino acid polypeptide sequence from the $\mathrm{N}$ terminus of Gillichthys mirabilis C/EBP- $\delta$. Details of its construction can be found in Buckley (2011). The efficacy of this antibody in recognizing C/EBP- $\delta$ in T. bernacchii and P. borchgrevinki was supported by the observation of a single band on all blots. The molecular weight of this band was $\sim 37 \mathrm{kDa}$, which is the size of C/EBP- $\delta$ in G. mirabilis and other fishes (Buckley 2011). Following primary incubation, blots were washed $3 \times 5$ min in $1 \times$ PBS $+0.1 \%$ 
Tween-20. Secondary incubations with HRP-conjugated goat anti-rabbit antibodies (Pierce) were performed at a dilution of 1:5000 in $1 \times$ PBS $+5 \%$ NFDM for $1 \mathrm{~h}$ at RT under constant shaking. Blots were then washed $6 \times 5 \mathrm{~min}$ in 1X PBS $+0.1 \%$ Tween-20 before being incubated with Super Signal (Pierce) chemiluminescent substrate. Blots were covered with plastic wrap and exposed to X-ray film (XOMAT-AR film, Kodak, Rochester, NY, USA).

\section{Data analysis and statistics}

Films were scanned and densitometry performed using Image J software. Background corrections were applied and mean pixel intensities were entered into GraphPad Prism software (GraphPad Software, Inc., La Jolla, CA, USA) for statistical analyses comprising Student's $t$ test (long-term heat acclimation study), one-way ANOVA with Tukey's multiple comparison test (short-course heat shock with recovery experiment) and two-way ANOVA with Bonferroni post-tests (long-course heat shock experiment). 


\section{Results}

Constitutive expression of $C / E B P-\delta$ in field-acclimated individuals

C/EBP- $\delta$ was expressed in the tissues of three field-caught $\left(-1.86 \pm 0.5^{\circ} \mathrm{C}\right)$, untreated T. bernacchii in a tissue-specific manner (Fig. 2). Greatest levels were detected in white muscle, followed by spleen, brain and gill. C/EBP- $\delta$ protein was not detected in liver or heart tissue. Given its high expression in white muscle, subsequent analyses prioritized this tissue for study.

\section{Long-term heat acclimation}

White muscle tissue from $T$. bernacchii held for one month at $4.0 \pm 0.5^{\circ} \mathrm{C}$ $(n=5)$ contained higher protein levels of C/EBP- $\delta$ when compared to $n=10$ field-acclimated individuals (Fig. 3; Student's $t$ test; $p<0.0001$ ). The mean value for the $4.0^{\circ} \mathrm{C}$-acclimated group was $\sim 1.6 \mathrm{X}$ that of the field-acclimatized group.

\section{Short-course heat shock with recovery}

In response to $4.0^{\circ} \mathrm{C}$ heat shock and subsequent recovery at $-1.0 \pm 0.5^{\circ} \mathrm{C}$, a reversible up-regulation of C/EBP- $\delta$ was observed in T. bernacchii white muscle tissue (Fig. 4). Mean C/EBP- $\delta$ protein levels after $6 \mathrm{~h}$ of heat stress were $8 \mathrm{X}$ higher than levels at time 0 (ANOVA; $p<0.05$ ). 


\section{Long-course heat shock}

Time and temperature had significant effects (two-way ANOVA $p<$ 0.0001 and $p<0.05$ respectively) on C/EBP- $\delta$ protein levels in T. bernacchii white muscle (Fig. 5, top panel). The interaction of these variables was also significant $(p=0.0001)$. Consistent with our results from the short-course study, $4.0^{\circ} \mathrm{C}$ heat stress caused an increase in C/EBP- $\delta$ protein levels after $6 \mathrm{~h}$ compared to control animals held at $-1.0 \pm 0.5^{\circ} \mathrm{C}$ (Bonferroni's posttest; $p<$ $0.01)$. This was the only time point where levels of C/EBP- $\delta$ differed among temperature treatments. Animals held at $2.0^{\circ} \mathrm{C}$ for $6 \mathrm{~h}$ possessed levels higher than controls $(p<0.001)$ and higher than levels in $4.0^{\circ} \mathrm{C}$ heat-stressed individuals $(p<0.01)$. Mean C/EBP- $\delta$ protein levels after $6 \mathrm{~h}$ at $2.0^{\circ} \mathrm{C}$ and after $6 \mathrm{~h}$ at $4.0^{\circ} \mathrm{C}$ were $26 \mathrm{X}$ and $\sim 13 \mathrm{X}$, respectively, greater than in the controls. There were no significant differences between temperature treatments at 24, 72, and $168 \mathrm{~h}$. For these last three time points, all values were significantly lower than the $6 \mathrm{~h} 2.0^{\circ} \mathrm{C}$ treatment group $(p<0.001)$. Results from gill tissue were unreliable due to methodological difficulties associated with extremely low C/EBP-delta protein concentrations. No significant differences were observed (data not shown). 
Spleen taken from the same individuals discussed above showed broadly similar patterns in C/EBP- $\delta$ levels to those observed in white muscle, but no significant differences were measured between treatment times or temperatures (Fig. 5, bottom panel). There was no correlation between body

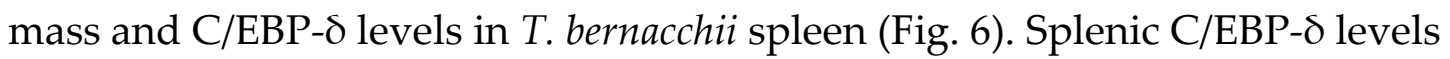
in P. borchgrevinki were responsive to time in the weeks following capture (Fig. 7; two-way ANOVA; $p<0.05)$. Temperature had no significant effect and there was no significant interaction between time and temperature.

\section{Discussion}

The stenothermal, cold-adapted fishes of the Southern Ocean display some of the lowest upper thermal thresholds of any animal (Somero and DeVries, 1967). Despite lacking the ability to induce a classic heat shock response (HSR) as a result of thermal stress exposure (Hofmann et al., 2000; Buckley et al., 2004), the common emerald rock cod Trematomus bernacchii does possess the ability to modulate the expression of hundreds of genes in response to heat (Buckley and Somero, 2009). However, open questions remain as to the degree to which mRNAs from heat-responsive genes in $T$. 
bernacchii are translated into protein and what the functional role of heatinducible proteins in this species, and its Antarctic relatives, might be. Here, I examined the expression of a mediator of arrest of the cell cycle and apoptosis, C/EBP- $\delta$, in the tissues of field-caught and thermally treated specimens. The results demonstrate that the clebpd gene is highly temperature-sensitive in this fish, despite the species' long evolutionary history spent in the extreme cold.

\section{Constitutive expression of $C / E B P-\delta$ in field-caught specimens}

A tissue-specific pattern of constitutive expression of C/EBP- $\delta$ was detected in field-acclimatized T. bernacchii (Fig. 1). Highest levels were observed in white muscle, followed by spleen, brain and gill; no detectable amounts of C/EBP- $\delta$ were measured in liver or heart tissue of field-caught specimens. Constitutive levels of C/EBP- $\delta$ have previously been reported in mammalian (e.g., Alam et al., 1991) and fish tissues (Buckley, 2011), suggesting that besides playing a role in stress responses, C/EBP- $\delta$ performs one or more housekeeping functions under non-stressful conditions. This phenomenon may be tissue- and species-specific, as, contrary to the case in T. bernacchii, constitutive levels of C/EBP- $\delta$ were detected in the liver of another fish species, the goby G. mirabilis (Buckley, 2011). Based on the established roles in 
cell fate determination of the C/EBP family of proteins, I postulate that the heat-induction of C/EBP- $\delta$ may be related to stress-related effects on cell growth, proliferation, and/or apoptosis in T. bernacchii. If there is an inverse relationship between tissue growth and C/EBP- $\delta$ levels, a notion supported by the anti-proliferative effects of C/EBP- $\delta$ in other systems, then our data suggest that under normal field conditions, the highest rates of cell proliferation and/or survival occur in liver and heart tissue and the lowest in the skeletal muscle, spleen and gill.

The high levels of C/EBP- $\delta$ in the skeletal muscle may be related to the fact that in notothenioid fishes, some species do not exhibit mosaic hyperplasia as adults and so muscle growth during development is due to larger, rather than a great number of, muscle fibers (Fernández and Calvo, 2009). Hypertrophy of existing fibers is supported by the division of myogenic progenitor cells (MPCs; Koumans and Akster, 1995). Brodeur et al. (2002) observed that $75 \%$ of MPCs in Harpagifer antarcticus were actively proliferating at the time of study. It is possible that the relatively high levels of C/EBP- $\delta$ in skeletal muscle are responsible for the growth arrest of previously proliferating MPCs as a mechanism by which further growth can be slowed or halted. In other systems, muscular atrophy caused by starvation, spaceflight 
or sepsis is correlated with C/EBP- $\delta$ activation, consistent with its roles in growth arrest and apoptosis (Penner et al., 2002; Chen et al., 2003; Allen et al., 2008; Allen et al., 2010). Foster et al. (2005) reported higher somatic indices for liver and heart, but not white muscle and gill, in cold-acclimated juvenile cod $\left(5^{\circ} \mathrm{C}\right.$ versus $\left.15^{\circ} \mathrm{C}\right)$. This is consistent with the results of the present study, in which liver and heart possessed the lowest amounts of C/EBP- $\delta$ suggesting a release from the activity of this cell cycle "brake"; however, additional studies are needed to investigate organ-specific mass scaling in Antarctic fishes under normal and heat-stressed conditions and how that might relate to transcriptional control of gene expression.

\section{Heat-induction of $C / E B P-\delta$}

Levels of C/EBP- $\delta$ protein were found to be highly sensitive to temperature treatment. White muscle tissue from T. bernacchii held for one month at $4.0^{\circ} \mathrm{C}$ contained significantly higher levels of $\mathrm{C} / \mathrm{EBP}-\delta$ when compared to field-acclimatized individuals (Fig. 2; Student's $t$ test; $p<0.0001$ ). The observed fold-change of 1.6 was modest in comparison to the fold changes observed during the short-course heat shock and recovery treatment. In that experiment, an 8-fold increase in white muscle C/EBP- $\delta$ levels was 
observed after $6 \mathrm{~h}$ at $4.0^{\circ} \mathrm{C}$, compared to levels at time 0 (Fig. 3; ANOVA; $p<$ 0.05). Interestingly, the effect was reversible, with levels decreasing during recovery to equivalency with those at time 0 (note that due to insufficient numbers of animals, only two individuals were sampled at the $24 \mathrm{~h}$ timepoint). The reversibility of the induction of this protein during recovery from heat stress is an important observation as it suggests a regulated response to thermal perturbation.

To characterize the effect of longer term heat treatments on C/EBP- $\delta$ levels, I exposed fish to $-1.0 \pm 0.5^{\circ} \mathrm{C}$ (control), $2.0^{\circ} \mathrm{C}$ and $4.0^{\circ} \mathrm{C}$ for up to one week and measured C/EBP- $\delta$ protein levels in white muscle and spleen tissue (Fig. 4). In white muscle, time, temperature and the interaction of these variables had significant effects on C/EBP- $\delta$ levels. Consistent with our results from the short-course study, C/EBP- $\delta$ levels in white muscle were elevated in the heat-stressed animals at the $6 \mathrm{~h}$ sample point. Perhaps surprisingly, the $2.0^{\circ} \mathrm{C}$ treatment yielded a greater effect than $4.0^{\circ} \mathrm{C}$; mean $\mathrm{C} / \mathrm{EBP}-\delta$ levels were respectively 26- and 13-fold higher than those found in control fish kept at $1.0 \pm 0.5^{\circ} \mathrm{C}$ for $6 \mathrm{~h}$. Values from the fish held at $2.0^{\circ} \mathrm{C}$ for $6 \mathrm{~h}$ were higher than any of the other treatment groups and there were no significant differences between temperature treatments at each subsequent timepoint past $6 \mathrm{~h}$, 
suggesting that the heat induction of C/EBP- $\delta$ in T. bernacchii is acute and transitory.

Interindividual variation in expression of C/EBP- $\delta$ was observed in spleen although no statistically significant differences were observed between treatment groups (Fig. 4, bottom panel). Expression of this gene in the spleen displayed what could be described as an "on or off" pattern, being highly expressed in some individuals and not at all in others. This was also the case in the field-caught specimens (Fig. 1). Time had a significant effect on C/EBP- $\delta$ levels in P. borchgrevinki spleen (Fig. 5), suggesting that tank effects alone may be enough to cause upregulation of this transcription factor in certain cases. Future experiments may benefit from longer periods of laboratory acclimation separating animal capture and treatment, on the order of weeks rather than days.

The observed increase in C/EBP- $\delta$ in white muscle is most likely sufficient to cause extensive transcriptomic restructuring during both shortand long-term heat response through the modulation of the expression of its target genes. The few studies that have investigated downstream targets of C/EBP- $\delta$ suggest that they number in the hundreds (Gery et al., 2005; Zhang et al., 2008). This, in concert with the fact that C/EBPs are regulated at multiple 
levels (e.g., post-translational modification, nuclear translocation and dimer formation), means that the precise functional implications of an increase in C/EBP- $\delta$ bear further study. However, it is reasonable to postulate that the heat-induction of C/EBP- $\delta$ observed in the present study indicates a change in cell status during exposure to heat stress, namely the regulation of cell cycle arrest and/or apoptosis. I hypothesize that in the absence of an inducible heat shock response and the lack of an ability to upregulate Hsps, non-lethal heat stress leads to an initiation of cell cycle arrest and therefore, cell survival, mediated at least in part by C/EBP- $\delta$. Considering the cold-adapted physiology and the stenothermality of this species, the ability to respond to small increases in temperature through adaptive modulation of gene expression may be especially important as ocean warming trends continue in the coming decades. To investigate the likely possibility that C/EBP-delta is controlling gene expression through the direct interaction genomic DNA in fishes, I measured nuclear levels of this transcription factor in control and heat-stressed T. bernacchii and P. borchgrevinki, as well as in the model zebrafish Danio rerio. 


\title{
Chapter 3: Nuclear accumulation of C/EBP- $\delta$ in heat stressed Danio rerio, Trematomus bernacchii and Pagothenia borchgrevinki
}

\begin{abstract}
CCAAT/enhancer-binding protein delta $(\mathrm{C} / \mathrm{EBP}-\delta)$ is a member of a family of eukaryotic transcription factors with important roles in inflammation, cell cycle arrest, cellular differentiation and apoptosis. Recent studies have demonstrated the temperature-sensitive expression of C/EBPs in some aquatic ectotherms, suggesting a possible role for these proteins in cellular responses to environmental stress. The regulatory mechanisms that govern the heat-induction of C/EBP- $\delta$ remain unclear, as do the functional ramifications of its upregulation during heat stress in ectotherms. To determine whether $\mathrm{C} / \mathrm{EBP}-\delta$ translocates to the nucleus during stress exposure allowing it to function as a transcription factor, immunohistochemistry was used to conduct a multiple-tissue screen of C/EBP- $\delta$ expression and subcellular localization in zebrafish (Danio rerio) held at $28.5^{\circ} \mathrm{C}$ or ramped to $35.5^{\circ} \mathrm{C}$. Sub-lethal heat stress resulted in the nuclear accumulation of C/EBP- $\delta$ protein in the white muscle and in neurons of the retina. In the case of retinal
\end{abstract}


ganglion cells, this was accompanied by an increase in DNA damage as determined by TUNEL assay. Photoreceptors, cardiac cells and spleen from the Antarctic fish species showed significant changes in nuclear C/EBP-delta concentration. Based on these results, I postulate that in defense of proper cellular functioning including visual processing in the retina, $C / E B P-\delta$ may regulate inflammation and/or cell survival during heat stress.

\section{Introduction}

Ectothermic animals, whose body temperatures vary with that of the environment, respond to thermal stress at all levels of organization from molecules to populations. For an individual, the response to environmental insult occurs on two intimately linked fronts: 1) the organismal stress response coordinated by way of the brain-sympathetic-chromaffin cell axis and brainpituitary-interrenal axis and 2) the more localized cellular stress response (CSR). In fish, the former is initiated by the central nervous system in response to a variety of cues such as thermal, handling and crowding stress, with the end result being the release of catecholamines and cortisol from the head kidneys (Wendelaar Bonga, 1997). These hormones have widespread effects 
on behavior and metabolism, including increases in cardiac output, oxygen uptake/transfer and blood glucose levels. They also effect striking systemic changes in gene expression via receptors on the target cells and second messenger signaling pathways. In contrast, the CSR is mounted by an individual cell. It is highly conserved across taxa and consists of four hallmarks: 1) macromolecular protection, 2) metabolic adjustment, 3) cell-cycle control and 4) apoptosis (Kültz, 2005). The first of these, protecting cellular macromolecules and proteins in particular, is the best understood (Fink, 1999; Feder and Hofmann, 1999). This process involves the classical heat shock response (HSR), defined as the marked upregulation of heat shock proteins (Hsps) in response to protein damage (Lindquist, 1986). Compared to the HSR, two other elements of the CSR - cell-cycle control and apoptosis - have enjoyed relatively little attention.

The CCAAT/enhancer-binding proteins (C/EBPs) are a family of basicleucine zipper transcription factors with diverse roles in normal and pathophysiological conditions (Lekstrom-Himes and Xanthopoulos, 1998; Ramji and Foka, 2002; Nerlov, 2007; Tsukada et al., 2011). First recognized as crucial mechanistic links between the regulation of gene expression and cellcycle control, C/EBPs mediate important processes including adipocyte 
differentiation, liver regeneration, inflammation, haematopoiesis and cell proliferation (Darlington et al., 1998; Diehl, 1998; Poli, 1998; Lane et al., 1999; Pabst et al, 2001; Nerlov, 2007). The six C/EBP isoforms $(\alpha,-\beta,-\gamma,-\delta,-\varepsilon,-\zeta)$ have been linked to various cancers, as they differentially exhibit tumor-promoting and/or tumor-suppressing functions. C/EBP- $\delta$ is generally regarded as antiproliferative (O'Rourke et al,. 1997; O'Rourke et al., 1999; Sivko and DeWille, 2004; Sanford and DeWille, 2005; Nerlov, 2007). It is under-expressed in human breast tumors (Porter et al., 2001; Porter et al., 2003), and the forced expression of $c / e b p-\delta$ in prostate and breast cancer cell lines dramatically reduces clonal growth (Ikezoe et al., 2005). Furthermore, in acute myeloid leukemia, the $c l e b p-\delta$ promoter can be silenced by hypermethylation, which prevents its expression (Agrawal et al, 2007). Together, these results build a convincing case for the role of $\mathrm{C} / \mathrm{EBP}-\delta$ as a brake on cell division, a so-called "molecular stop sign" that when abnormally under-expressed can lead to pathogenic states (Johnson, 2005). However, it has also been shown that C/EBP- $\delta$ can inhibit the tumor suppressor FBXW7 and promote mammary tumor metastasis (Balamurugan et al., 2010). In other cellular contexts, the induction of $c / e b p-\delta$ may be pro-apoptotic. For instance, C/EBP- $\delta$-null mice exhibited decreased expression of the pro-apoptotic regulators Bak and Bax, 
and increased expression of cyclin D1, Bfl-1, and Bcl-w during delayed mammary gland involution (Thangaraju et al., 2005).

To date, the vast majority of $\mathrm{C} / \mathrm{EBP}$ research has utilized mammalian models to focus on biomedical applications, but a growing body of evidence now points to roles for C/EBP- $\delta$ in responding to environmental insult via the CSR in aquatic ectotherms. Recent cDNA microarray studies have collectively demonstrated in taxa as diverse as teleost fishes, anthozoans and bivalve mollusks, that each C/EBP isoform has the ability to be induced by heat at the mRNA level in at least one species, and in some cases several (Buckley et al., 2006; Kassahn et al., 2007; Desalvo et al., 2008; Gracey et al., 2008; Richier et al., 2008; Buckley and Somero, 2009; Castilho et al., 2009). The target species of these studies comprise both eurythermal and stenothermal species from polar, temperate, and tropical environments, suggesting an important general role for C/EBPs during periods of environmental temperature stress. In addition to induction at the mRNA level, C/EBP- $\delta$ was induced at the protein level in gill, liver and white-muscle tissue from heat-shocked individuals of the estuarine goby Gillichthys mirabilis (Buckley, 2011). Heat stress also led to an increase in $\mathrm{C} / \mathrm{EBP}-\delta$ protein concentration in white muscle from the Antarctic fish Trematomus bernacchii (Chapter 2; Sleadd and Buckley, 2013). I hypothesize 
that increases in $\mathrm{C} / \mathrm{EBP}-\delta$ concentration might have an important function in modulating inflammation, cell-cycle progression, and/or apoptosis during periods of environmental stress; however, the signaling pathways underlying the heat induction of $\mathrm{C} / \mathrm{EBP}-\delta$, as well as its precise physiological implications, remain unclear.

In order to infer a functional significance of the induction of $\mathrm{C} / \mathrm{EBP}-\delta$ and its activity as a transcriptional regulator, it is necessary to demonstrate its nuclear localization in response to heat treatment. In the present study, I investigated the expression and sub-cellular localization of C/EBP- $\delta$ in heatshocked zebrafish, Danio rerio, in an organism-wide tissue screen. I present evidence for the nuclear accumulation of C/EBP- $\delta$ in retinal and muscle cells from heat-stressed individuals, as well as an increase in DNA damage within retinal ganglion cells, which co-occurred with the upregulation of C/EBP- $\delta$. Nuclear levels of this transcription factor also vary with temperature stress in P. borchgrevinki retinae and spleen, and in cardiac tissue from T. bernacchii. 


\section{Materials and Methods}

\section{Animal maintenance}

Adult wildtype zebrafish, Danio rerio (Hamilton) were maintained, heat-treated and sacrificed under protocols approved by Portland State University's Institutional Animal Care and Use Committee. Animals were acquired from a local commercial supplier and laboratory-acclimated for three weeks. During this time, animals were maintained in an aerated and filtered ten-gallon aquarium at $28.5^{\circ} \mathrm{C}$ on a 14 -h light, 10 -h dark cycle. Twenty-percent water changes were conducted every day. Fish were fed daily on a diet of tropical fish flakes $\left(\right.$ Tetra $\left.{ }^{\circledR}\right)$, but were starved on the day of experimentation. Specimens of Trematomus bernacchii and Pagothenia borchgrevinki were collected and maintained as describe in chapter 2 .

\section{Heat treatments}

Following laboratory-acclimation, eight fish were randomly divided into heat-stress and control groups. Each treatment took place in a 1-L beaker filled with 600-mL of constantly aerated aquarium water and each beaker was placed in one of two water baths held initially at $28.5^{\circ} \mathrm{C}$. Control fish $(n=4)$ were maintained at $28.5^{\circ} \mathrm{C}$ for the duration of the experiment ( $5 \mathrm{~h} 25 \mathrm{~min}$ ). 
Animals in the heat-stressed group $(n=4)$ were subjected to warming water temperatures at a rate of $+2.0^{\circ} \mathrm{C}$ per hour (Fig. 8). Once the water reached $35.5^{\circ} \mathrm{C}$, fish were held at that temperature for $2 \mathrm{~h}$ before being sacrificed along with the control fish by brief immersion in ice water followed by cervical transection. T. bernacchii and P. borchgrevinki were heat stressed as described in chapter 2.

\section{Tissue fixation and slide preparation}

Immediately following sacrifice, whole zebrafish were immersed in $10 \%$ neutral-buffered zinc formalin solution for $4 \mathrm{~d}$, then transferred to $70 \%$ ethanol to await processing by Histology Services at the Oregon National Primate Research Center (Oregon Health Sciences University, Beaverton, OR, USA). One control and one heat-stressed fish were paired into each of four paraffin blocks, which were then sectioned sagitally at $5 \mu \mathrm{m}$ to produce both haematoxylin- and eosin-stained slides as well as unstained slides for immunohistochemistry.

T. bernacchii and P. borchgrevinki were sacrificed by cervical transection. Samples of brain, eye, gill, heart, liver, spleen and white muscle were immersed in $10 \%$ neutral-buffered zinc formalin solution for $36 \mathrm{~h}$, then 
transferred to $70 \% \mathrm{EtOH}$. Samples were shipped to Portland, Oregon, where they were processed by OHSU histology services. Three control and three heat-stress samples were paraffin imbedded, sliced and affixed to each microscope slide.

\section{Immunohistochemistry}

DAB immunostaining was conducted using a custom rabbit antiC/EBP- $\delta$ antibody (Affinity BioReagents ${ }^{\mathrm{TM}}$, Golden, CO, USA) made against a 15-aa polypeptide sequence obtained from the goby Gillichthys mirabilis (Cooper). Using western blotting, my lab has previously demonstrated the effectiveness of this antibody at detecting C/EBP- $\delta$ in G. mirabilis, T. bernacchii and P. borchgrevinki (Buckley, 2011; Sleadd and Buckley, 2013; chapter 2 of this dissertation). Consistent with those results, I observed a single 33-kDa band in D. rerio tissues in western blots employing this antibody (data not shown).

Unstained slides were hydrated through a series of xylene and graded alcohol baths, followed by a brief rinse in distilled water and $5 \mathrm{~min}$ in phosphate-buffered saline (PBS). Antigen retrieval was accomplished by microwaving or boiling samples at full pressure for $5 \mathrm{~min}$ in a pressure cooker containing $10 \mathrm{mM}$ sodium citrate, $\mathrm{pH}$ 6.0. After cooling for 20 to 60 minutes, 
slides were soaked for $30 \mathrm{~min}$ in methanol containing $0.3 \%$ hydrogen peroxide to quench endogenous peroxidases. Slides were washed $3 \times 5 \mathrm{~min}$ in PBS. Tissue sections were blocked 30 to 60 min with $2.5 \%$ normal horse serum (NHS) in PBS, then washed $3 \times 5$ min in PBS. Samples were incubated with the custom anti-C/EBP- $\delta$ antibody diluted 1:800 in 2.5\% NHS in PBS overnight at $4^{\circ} \mathrm{C}$ in a humidified chamber. A negative control slide was simultaneously incubated overnight in 1 x PBS and 2.5\% NHS lacking primary antibody (Fig. 9). The next morning, slides were washed $3 \times 5 \mathrm{~min}$ in PBS, then incubated with ImmPRESS ${ }^{\mathrm{TM}}$ anti-rabbit Ig peroxidase reagent (Vector Labs, Burlingame, CA, USA) for $30 \mathrm{~min}$. These were washed $3 \times 5 \mathrm{~min}$ in PBS, followed by DAB color development using a DAB peroxidase substrate kit (Vector Labs) according to manufacturer's instructions.

For nuclear counterstaining, slides were dipped in Harris haematoxylin for 3 to 5 seconds, followed by a rinse in distilled water and 5 min in tap water. Tissues were destained by quick immersion in acid ethanol $(0.1 \% \mathrm{HCl}+$ $70 \% \mathrm{EtOH}$ ) followed by $5 \mathrm{~min}$ in tap water and $5 \mathrm{~min}$ in distilled water. Finally, slides were dehydrated using a graded alcohol series plus xylene, and coverslips were mounted using Permount ${ }^{\mathrm{TM}}$. 
TUNEL assay

Terminal deoxynucleotide transferase-mediated dUTP nick end labeling (TUNEL) was carried out on zebrafish sections as a measure of DNA damage related to apoptosis, using the APO-BrdUTM IHC reagent kit (Phoenix Flow Systems, San Diego, CA, USA) according to manufacturer's directions. TUNEL-positive cells yielded a DAB color development and nuclei were counterstained with methyl green. For retinal ganglion and amacrine cells, TUNEL-positive nuclei were reported as a proportion of total. A positive control slide was run alongside the zebrafish sections that contained a human promyelocytic leukemia cell line (HL60) incubated with $0.5 \mu \mathrm{g} / \mathrm{ml}$ actinomycin $\mathrm{D}$ for $19 \mathrm{~h}$ to induce apoptosis (Fig. 10; cells provided by Phoenix Flow Systems).

\section{Image acquisition and manipulation}

Slides were visualized in brightfield using a Leica DM IRB inverted microscope (Leica, Heerbrugg, Switzerland). Photographs were captured using a DC480 digital camera with IM50 software (Leica). Background correction was applied by dividing the sample images by empty background images and multiplying the result by a scaling factor of 255 . This was done using ImageJ freeware equipped with the Image Calculator Plus plugin 
(http://imagej.nih.gov). Color deconvolution was carried out using a color deconvolution plugin using built-in stain vectors (Landini, 2010). For quantification by densitometry, DAB-channel images were converted to grayscale and inverted before mean pixel intensities were determined using ImageJ. Nuclei were selected by converting the haematoxylin channel images to binary and creating a selection which was then carried over to the inverted grayscale manipulations of the DAB channel images. Mean pixel intensities were recorded. Cell counts were carried out when clearly differentiated staining was observed (i.e., TUNEL positivity of retinal ganglion and amacrine cells).

\section{Statistics}

Student's $t$ tests, one-way ANOVA and Grubbs test for outliers were conducted using GraphPad Prism ${ }^{\circledR} 4$ software (GraphPad Inc., La Jolla, California, CA, USA). 


\section{Results}

\section{Zebrafish}

Sagittal sections of adult zebrafish were stained for C/EBP- $\delta$ using DAB IHC in order to examine sub-cellular localization of this transcription factor under heat-stress $\left(35.5^{\circ} \mathrm{C}\right)$ and control $\left(28.5^{\circ} \mathrm{C}\right)$ conditions. An organism-wide tissue screen revealed the greatest heat-induced changes in C/EBP- $\delta$ concentration to be in the retina and white muscle. I observed elevated levels of $\mathrm{C} / \mathrm{EBP}-\delta$ via $\mathrm{DAB}$ staining in neuronal nuclei from heat-stressed $D$. rerio retinae (Figs. 11-13). Deconvoluted images were used for quantification via densitometry (Fig. 14). Highest-fold changes were observed for nuclei of the outer nuclear layer (ONL; $2.02 \pm 0.48 \mathrm{SD})$, retinal ganglion cells (RGC; $2.00 \pm$ 0.29 ), and inner nuclear layer (INL; $1.66 \pm 0.30$ ). Lower-fold changes were observed among the neuropil layers of the inner plexiform layer (IPL; $1.48 \pm$ 0.18 ) and outer plexiform layer (OPL; $1.15 \pm 0.25)$. The photoreceptor layer (PL; $0.98 \pm 0.03)$ showed no densitometric difference between treatments, but PLs from heat-stressed animals displayed a more even distribution of C/EBP- $\delta$ DAB positivity when compared to controls (Figs. 12-13). For each layer, the mean difference in DAB intensity between control and heat-stressed fish were compared to a hypothetical mean of 0 via Student's $t$ test. There was a trend 
towards over-expression of C/EBP- $\delta$ in heat-stressed nuclei in every cell type except PL (Fig. 14; Table 3.1). There was a significant increase in the DAB intensity from heat-stressed fish compared to controls in the RGCs. Although the mean differences were not statistically different from 0.0 for the other layers using the chosen densitometric method, comparisons from the ONL, INL and IPL yielded $p$ values $\leq 0.09$ (Student's $t$ test).

TUNEL assays performed on tissue sections revealed increased DNA damage among RGC nuclei (Fig. 11). One data point from a control individual was a statistical outlier according to Grubbs test $(p<0.05)$. When this data point was excluded, temperature had a significant effect on TUNEL positivity of $D$. rerio RGCs (Student's $t$ test; $p<0.05$ ). Amacrine cells showed a similar trend, but the effect was not significant (Fig. 11; $p=0.13$ ).

A significant increase in nuclear $\mathrm{C} / \mathrm{EBP}-\delta$ concentration was also measured in white muscle (Fig. 15; one-sample $t$ test; $p<0.05$ ). Levels of C/EBP- $\delta$ were $~ 1.25$ times higher in heat-stressed individuals than in control individuals.

Nuclei from glial cells within optic tectum white matter also showed increased DAB intensity, though marked nuclear shrinkage and perinuclear haloes made this result difficult to interpret (Figs. 16-18); size-corrected 
nuclear concentrations of C/EBP- $\delta$ were nearly statistically different between temperature treatments (Student's $t$ test; $p=0.07$ ). No differences in DAB intensity or TUNEL staining between control and heat-stressed fish were observed in gill or liver (Figs. 19-20; gill not shown).

\section{Pagothenia borchgrevinki and Trematomus bernacchii}

I analyzed sections of retina, gill, heart, liver, spleen and white muscle from T. bernacchii and P. borchgrevinki held at $4.0^{\circ} \mathrm{C}$ or $-1.0 \pm 0.5^{\circ} \mathrm{C}$ for $6 \mathrm{~h} . P$. borchgrevinki held for $168 \mathrm{~h}$ were also analyzed (Figs. 24-37). Images from the 6 $\mathrm{h}$ time point and from T. bernacchii were similar and are not shown.

In general, temperature did not appear to have a significant effect on nuclear C/EBP-delta levels, with a few exceptions. In P. borchgrevinki spleen, 6 $\mathrm{h}$ at $4.0^{\circ} \mathrm{C}$ caused a significant decrease in nuclear C/EBP-delta concentrations (Fig. 22). Photoreceptor nuclei in this species showed a significant increase in nuclear C/EBP-delta concentrations after $168 \mathrm{~h}$ (Fig. 23). In T. bernacchii, heart tissue showed a significant decrease after $6 \mathrm{~h}$ at $4.0^{\circ} \mathrm{C}$ (student's $t$ test; $p<0.01$; Fig. 21), while gill tissue showed a nearly significant increase (student's $t$ test; $p=0.0613)$ 


\section{Discussion}

Acute exposure to stressful environmental temperatures, as well as to longer-term thermal acclimation, can induce C/EBP- $\delta$ expression in various aquatic ectotherms (e.g., Buckley et al., 2006; Buckley and Somero, 2009;

Castilho et al., 2009; Buckley, 2011; Sleadd and Buckley, 2013; Chapter 2 of this dissertation), but the pathways and mechanisms by which C/EBP- $\delta$ is regulated in response to temperature are unknown. Because C/EBP- $\delta$ must translocate to the nucleus in order to function, I examined the sub-cellular localization of C/EBP- $\delta$ protein in whole-sectioned zebrafish following heat stress treatments to further investigate the functional significance of the stressinduced expression of this transcriptional regulator. I also investigated multiple tissues from two Antarctic fishes, Trematomus bernachii and Pagothenia borchgrevinki, under normal and heat-stressed conditions.

\section{Heat-induced nuclear accumulation of $C / E B P-\delta$}

All tissues were scanned for C/EBP- $\delta$ expression and visually marked nuclear accumulation of $\mathrm{C} / \mathrm{EBP}-\delta$ in retinal neurons and white muscle from heat-stressed individuals was observed in D. rerio (Figs. 11-15). Analysis of the difference between C/EBP- $\delta$ in nuclei (as inferred from intensity of DAB 
staining) from heat-shocked vs control individuals yielded means that were always greater than zero (with the exception of PL cells) but these values were not statistically significant except in the case of retinal ganglion cell nuclei (Fig. 14). In P. borchgrevinki, $4.0^{\circ} \mathrm{C}$ heat stress caused significant accumulation of C/EBP-delta in photoreceptor nuclei after $168 \mathrm{~h}$ (Fig. 23). It should be noted that quantification of IHC is a contentious issue due to a variety of technical issues (reviewed in Taylor and Levenson, 2006) and is often disfavored over simple presence/absence cell counts. In control fish, I observed constitutive levels of C/EBP- $\delta$ in the cytoplasm of all tissues. This is in keeping with earlier observations that C/EBP- $\delta$ protein is produced constitutively in the gill, liver and muscle tissue of another fish species, Gillichthys mirabilis (Buckley, 2011). Induction of C/EBP- $\delta$ in retinae has been observed elsewhere (Gerhardinger et al., 2005). Diabetic Müller cells from rat retinae showed a 7.9fold increase in C/EBP- $\delta$ expression when compared to controls, suggesting it may be a key regulator of the acute phase response in these glial cells (Gerhardinger et al., 2005). Studies focused on other aspects of the nervous system have also identified this gene as potentially important. Repeated pulses of serotonin lead to the induction of Aplysia C/EBP in sensory neurons and this was required for consolidation of long-term memory in these animals 
(Alberini et al., 1994). In highlighting a role for C/EBP- $\delta$ in memory and fear conditioning in mice, Sterneck et al. (1998) observed wide-spread expression of this transcription factor in brain and spinal cord, especially among neurons of the dorsal root and sympathetic ganglia. In retinal ganglion cells from rat, axotomy combined with lens injury led to an upregulation of C/EBP- $\delta$ concomitant with axon regeneration and therefore cell restructuring (Fischer et al., 2004). In a study of three prosaposin-deficient mouse models exhibiting neurodegeneration, $\mathrm{C} / \mathrm{EBP}-\delta$ was the only transcript out of hundreds that was up-regulated in both cerebra and cerebella in all three models (Sun et al., 2008). Humans with Alzheimer's disease showed elevated levels of $C / E B P-\delta$ in their brain tissue, especially within astrocytes adjacent to amyloid beta deposits (Li et al., 2004). This is especially interesting, since both heat-induced proteotoxic stress and Alzheimer's involve the aggregation of misfolded proteins. Finally, C/EBP- $\delta$ was induced following traumatic brain injury in rat cerebral cortex, and is thought to have a neuroprotective role (von Gertten et al., 2005). Together, these studies underscore the importance of C/EBP- $\delta$ regulation in the nervous system and suggest many possible regulatory mechanisms underlying its heat-induction, including those associated with axon damage, hypoxia, blood glucose levels, and protein aggregation. 
Potential regulatory pathways controlling C/EBP- $\delta$ expression during heat stress

Although the pathways controlling the expression of C/EBP- $\delta$ in response to temperature are unclear, the regulation of C/EBPs in other contexts, and their molecular structures, are reasonably well understood (Ramji and Foka, 2002). Encoded by an intronless gene, the C/EBP- $\delta$ protein consists of a leucine zipper, basic region and activation domains (Tsukada et al, 2011). To acquire transactivation potential, C/EBP- $\delta$ translocates to the nucleus where it forms homodimers and heterodimers with other C/EBPs and/or additional transcription factors (Williams et al., 1991). Upstream activators of C/EBP- $\delta$ are known to include glucocorticoid, growth hormone, IFN- $\gamma$, IL-1, IL-6, insulin, LPS, noradrenaline, PDGF, TNF- $\alpha$ and VIP (Ramji and Foka, 2002; Johnson, 2005; Nerlov, 2007). Agents that cause the nuclear localization of C/EBP- $\delta$ in some systems include TNF- $\alpha$ and cAMP (Billiard et al., 2001).

Regulation of de novo C/EBP- $\delta$ mRNA expression in mammals in some cases involves signal transducer and activator of transcription 3 (STAT-3) (Clarkson et al., 2006). The induction of C/EBP- $\delta$ in mammary epithelial cells treated with interleukin 6 (IL-6) is dependent upon the activation, through 
phosphorylation, of Stat3 (Cantwell et al., 1998). Dr. Buckley identified a Stat3 binding site, the acute phase response element (APRE), in the $5^{\prime}$ untranslated region of the G. mirabilis clebp- $\delta$ gene, supporting a role for Stat 3 as a regulator of C/EBP- $\delta$ in fishes (Buckley, 2011). I followed this up with some proteinlevel analysis via western blotting (see appendix).

The observed nuclear accumulation of C/EBP- $\delta$ in white muscle during heat stress could have been initiated by neuroendocrine or cellular processes, or both. The neuroendocrine stress response is initiated by the central nervous system and results in the release of catecholamines and glucocorticoids from the kidneys (Wendelaar Bonga, 1997). In addition to widespread effects on metabolism and behavior, both classes of hormones are known to activate C/EBP- $\delta$ (Cardinaux and Magistretti, 1996). The neurotransmitter dopamine, and to a lesser degree epinephrine (Epi) and norepinephrine (NE), can stimulate adenylate cyclase and increase cAMP concentrations (Brown and Makman, 1972). Because cAMP is known to trigger the nuclear translocation of C/EBP- $\delta$ via cAMP-dependent protein kinase A (Billiard et al., 2001), a similar process may be responsible for the nuclear localization observed in the present study. 
Facets of the locally controlled CSR may also have contributed to the induction of C/EBP- $\delta$. The proteasome inhibitor MG-132 activates C/EBP- $\delta$ in human intestinal epithelial cells and this effect is blocked by the HSF1 inhibitor quercetin, suggesting that $\mathrm{C} / \mathrm{EBP}-\delta$ is induced by some component of the HSR (Hungness et al., 2001). C/EBP- $\delta$ may therefore serve as a link between macromolecular damage and certain of the anti- and pro-apoptotic effects of HSPs (Garrido et al., 2001; Beere, 2005; Thangaraju et al., 2005). C/EBPs were first recognized for their roles in cell-cycle control, one of the four hallmarks of the CSR. As sometimes potent effectors of cell-cycle arrest in cancer cells, a great deal of research has prioritized their characterization in this regard (Porter et al., 2001; Porter et al, 2003; Tang et al., 2005; Yu et al., 2010). Precisely how heat stress affects cell-cycle control in aquatic ectotherms remains unclear, but one possible consequence of the heat-induction and nuclear translocation of C/EBP- $\delta$ in these animals could be an adaptive, transient halt of the cell cycle. By allocating energy away from DNA synthesis and cell division, a cell could prioritize macromolecular chaperoning and thus avoid unnecessary cell death. If the stress is so severe that cells are irreparably damaged, then C/EBP- $\delta$ may play a role in triggering apoptosis (Thangaraju et al., 2005). 
Oxidative stress can be a by-product of heat exposure and it is possible that reactive oxygen species (ROS) and/or hypoxia play a role in inducing C/EBP- $\delta$ during thermal stress. For instance, hypoxia triggers the release of pro-apoptotic tumor necrosis factor alpha (TNF- $\alpha$ ) from retinal glial cells (Tezel and Wax, 2000), which can in turn cause the nuclear translocation of C/EBP- $\delta$ (Yin et al., 1996). The latter study, similar to the trend observed here, reported a 2-fold increase in nuclear C/EBP- $\delta$ in RGCs. Recent microarray studies have not seen the heat-induction of TNF- $\alpha$ in fishes per se; however, the ADAM17 precursor which converts TNF- $\alpha$ to its soluble form is heatinducible in Gillichthys mirabilis gill and white muscle (Buckley et al., 2006). Many of the regulatory pathways mentioned above are summarized graphically in figure 49 .

\section{Heat-induced DNA damage in retinal cells}

Using TUNEL assays, I observed an increase in DNA damage in RGCs from heat-stressed zebrafish (Fig. 11). Raised body temperature causes an increase in metabolism, which should in turn lead to oxidative stress via the production of reactive oxygen species. This can have detrimental effects on the integrity of proteins, lipids and DNA, so the defense against oxidative stress is 
a high priority for marine organisms (Lesser, 2006). Most reactive oxygen intermediates cannot directly damage DNA; instead, they react via Fenton chemistry with transition metals (Henle and Linn, 1997). ROS production in low, intermediate and high doses can cause cell proliferation, growth arrest and cell death respectively; furthermore, ROS is known to activate signaling pathways upstream of C/EBP- $\delta$ including JAK/STAT3 and HSF1 (Hutt et al., 2000; Hungness et al., 2001; Martindale and Holbrook, 2002). It is therefore likely that heat stress, ROS production, macromolecular damage and repair pathways have complex and overlapping effects on C/EBP- $\delta$ activity and cell fate determination.

\section{Concluding remarks}

The heat-induction of C/EBP- $\delta$ in aquatic ectotherms may translate to adaptive changes in cell fate during exposure to environmental stress. Whether this involves cell-cycle arrest, apoptosis or both is a question that bears further study. Likewise, additional research should be focused on the characterization of the pathways involved in regulating these processes through the activity of C/EBP- $\delta$ as a transactivator and the further changes in gene expression that occur as a result. The ultimate goal should be to integrate 
the activity of this important transcription factor into our understanding of the broader cellular response to thermal stress and other environmental insults. First, it is important to clearly demonstrate whether or not sublethal heat stress causes a dysregulation of cell cycle which, if present, may be correlated with C/EBP-delta expression. The next two chapters attempt to answer these questions in the Antarctic fish Trematomus bernacchii. 


\title{
Chapter 4: Protein levels of proliferating cell nuclear antigen (PCNA) in field-acclimated and heat-stressed Trematomus bernacchii
}

\begin{abstract}
Marine fishes living nearest the continent of Antarctica have body temperatures at or near the freezing point of seawater $\left(-1.86^{\circ} \mathrm{C}\right)$. This has been the case for at least 10-14 million years, during which time a number of biochemical adaptations have arisen to offset the effects of extreme cold as well as the presence of ice. Antifreeze glycoproteins and cold-adapted enzymes are well documented in polar ectotherms as is the lack of a classical "heat shock response." Recent transcriptomic and protein-level studies in my lab indicate that Trematomus bernacchii, a common Notothenioid fish, is able to respond to heat stress by upregulating numerous gene products including C/EBP- $\delta$. This transcription factor is associated with cell cycle arrest and apoptosis, two understudied hallmarks of the cellular stress response (CSR). To determine whether C/EBP- $\delta$ levels are correlated with cell cycle in heatstressed T. bernacchii, proliferating cell nuclear antigen (PCNA) levels were measured in field-acclimated $\left(-1.86 \pm 0.5^{\circ} \mathrm{C}\right)$ and heat-stressed $\left(2.0\right.$ or $\left.4.0^{\circ} \mathrm{C}\right)$
\end{abstract}


animals. PCNA levels in unstressed, field-acclimated fish were highly tissue specific with highest levels found in spleen and none detected in white muscle tissue. The tissue specificity reported here is similar to that of ubiquitinconjugated protein levels in T. bernacchii described previously. Heat stress and duration of treatment had complex and interacting effects on PCNA protein levels in T. bernacchii, suggesting dysregulation of the cell cycle. Surprisingly, PCNA levels appear to be positively correlated with C/EBP- $\delta$ protein concentration in control, but not heat-stressed, individuals. These findings are discussed within the context of cold evolution, CSR and future climate change.

\section{Introduction}

The creation of the circumpolar current during the Cenozoic eliminated virtually all of the endemic Antarctic taxa by triggering a period of extreme cooling and glaciation (Kennett, 1977; Eastman, 1993; Zachos et al., 2001;

DeConto and Pollard, 2003; Shevenell et al., 2004). The benthic, temperate fishes that survived were able to do so because they acquired the biochemical adaptations necessitated by a subfreezing and ice-filled environment (Coppes Petricorena and Somero, 2007; Matschiner et al., 2011). This ancestral stock 
underwent an adaptive radiation similar to the species flock of East African cichlids, and its 120+ descendant species now occupy all possible niches within the water column - from solitary benthic to schooling cryopelagic species (Eastman, 1993; Eastman and McCune, 2000; Matschiner et al., 2011; Rutschmann et al., 2011). Body temperatures for the highest-latitude animals have remained below $0^{\circ} \mathrm{C}$ for at least the past 14 million years, during which time they have evolved antifreeze glycoproteins and cold-adapted enzymes (DeVries, 1971; Fields and Somero, 1998). They have the lowest upper-lethal temperature of any organism $\left(6^{\circ} \mathrm{C}\right.$; DeVries and Somero, 1967), and they are among the few taxa that lack the ability to upregulate heat shock proteins (Hsps) in response to thermal stress (Hofmann et al., 2000; Buckley et al., 2004; Buckley and Somero, 2009).

The "heat shock response (HSR)," is historically defined as the induction of the Hsp family of molecular chaperones (HSR; Lindquist, 1986; Feder and Hofmann, 1999). Thus, it is often said that Antarctic fishes lack a heat shock response. However, an increasing number of studies indicate that Antarctic fishes are indeed able to respond to heat stress without varying the production of Hsps. Scores of mRNA transcripts are down- or upregulated in response to sublethal heat stress in the common Antarctic fish Trematomus 
bernacchii (Buckley and Somero, 2009). Thermal acclimation increases heat tolerance in T. bernacchii and its congener T. pennellii (Podrabsky and Somero, 2006). Acute heat stress leads to catecholamine release (Forster et al., 1998) and increased hematocrit and hemoglobin concentrations (Davison et al., 1994) in T. bernacchii, as well as the cryopelagic Pagothenia borchgrevinki. Thermal adaptation of cardiac performance and metabolism has also been reported in Antarctic fishes (Seebacher et al., 2005; Franklin et al., 2007). For these sensitive species, initial reports of thermal intolerance seem to have been exaggerated. They are indeed able to respond to heat stress despite their extreme stenothermality and lack of an inducible HSR, although the molecular mechanisms underlying this capacity remain largely unknown. Likely players include those genes products whose functions lie within the non-chaperoning divisions of the cellular stress response.

Molecular chaperoning is just one of four hallmarks of the (mostly) conserved cellular stress response (CSR; Kültz, 2005). Two facets of the CSR which have received relatively little attention are cell cycle regulation and apoptosis. Since Antarctic fishes lack the ability to induce Hsp production, it is important to ask what other cellular strategies are employed by these species during thermal stress. Recent studies in my lab have demonstrated the heat 
induction of the CCAAT/Enhancer-binding protein-delta (C/EBP- $\delta)$ transcription factor in T. bernacchii (Buckley and Somero, 2009; Sleadd and Buckley, 2013; Chapter 2). This and other members of the C/EBP family are strongly associated with cell-cycle arrest and, to a lesser degree, apoptosis (Lekstrom-Himes and Xanthopolous, 1998; Ramji and Foka, 2002). Recent cDNA microarray and protein-level studies have revealed heat-sensitive C/EBP expression profiles in a variety of marine ectotherms including fishes, cnidarians and molluscs (Buckley et al., 2006; Kassahn et al., 2007; Desalvo et al., 2008; Gracey et al., 2008; Richier et al., 2008; Castilho et al., 2009; Buckley, 2011). It is therefore reasonable to assume that C/EBP transcription factors are molecular players in the CSR. Because C/EBP- $\delta$ is heat-inducible in $T$. bernacchii and other organisms, I hypothesize that an adaptive increase in $\mathrm{C} / \mathrm{EBP}-\delta$ protein concentration may reflect the initiation of cell-cycle arrest and/or apoptosis during times of thermal stress (Buckley, 2011; Sleadd and Buckley; 2012). To further investigate this hypothesis, I measured protein concentrations of proliferating cell nuclear antigen (PCNA), an established marker of cell proliferation, in a variety of tissues from field-acclimated and heat-stressed T. bernacchii. 
PCNA is a eukaryotic protein that was originally identified as a processivity factor for replicative DNA polymerases, but which is now recognized as a "dancer with many partners" (Miyachi et al., 1978; Bravo et al., 1987; Maga and Hübscher, 2003). For instance, this factor is necessary for DNA excision repair (Shivji et al., 1992), and has been shown to interact with the growth arrest and DNA damage associated protein Gadd45 (Smith et al., 1994). PCNA is a taxonomically well-conserved protein that functions as a sliding clamp by forming a homotrimeric ring around the DNA double helix (Krishna et al., 1994). By associating with a polymerase and its DNA template simultaneously, PCNA increases the continuity of DNA synthesis and therefore the efficiency of genome replication. Expression during the cell cycle begins in late G1 and peaks during S phase, thus protein concentration of PCNA is a popular marker for DNA synthesis (Kurki et al., 1986). PCNA immunolocalization in paraffin sections is a widely used index for cell proliferation (Hall et al., 1990). Furthermore, cells in different "sub-stages" of $S$ phase exhibit distinct patterns of PCNA subcellular localization (Celis and Celis, 1985), allowing for even more precise characterization of cell cycle progression. 
Very few studies have investigated PCNA levels or cell cycle in Antarctic fishes. Feeding led to increased PCNA expression in myogenic progenitor cells in Notothenia coriiceps and Harpagifer bispinis (Brodeur et al., 2002; Brodeur et al., 2003b), and the same group used cumulative S-phase labeling with 5-bromo-2'-deoxyuridine (BrdU) to determine myogenic progenitor cell cycle durations in two Harpagifer species (Brodeur et al., 2003a). The cell cycle in $\mathrm{H}$. antarcticus lasted $111 \mathrm{~h}(\mathrm{~S}$-phase duration $=37 \mathrm{~h})$ at $0^{\circ} \mathrm{C}$, which by comparison to its lower-latitude congener $H$. bispinis suggests evolutionary cold compensation of cell cycle time. In contrast with those studies' long-term acclimatory and evolutionary foci, the present study investigates cell cycle stage in an acutely heat-stressed Antarctic fish species. Specimens of Trematomus bernacchii were held at $-1.0 \pm 0.5,2.0$ or $4.0^{\circ} \mathrm{C}$ and sacrificed at 6, 24, 72 and $168 \mathrm{~h}$. Multiple tissues were sampled at time of death, and PCNA protein concentrations were determined by western blot. PCNA levels were compared to C/EBP- $\delta$ protein concentrations in order to test the hypothesis that these two variables would show an indirect relationship to one another. In response to questions of age-related organ scaling: the potential for covariate analyses including body mass data was opposed by a paucity of such data. Nevertheless, the available body mass data 
were plotted against PCNA protein concentrations, and the resulting scatter

plots were surveyed qualitatively for possible relationships between these two variables.

\section{Materials and Methods}

\section{Animal collection and maintenance}

Specimens of Trematomus bernacchii (Boulenger) were collected from McMurdo Sound during the austral spring of 2005 (field-acclimated cohort) and 2010 (heat-stress experimental group). Fish were captured by hook and line through holes drilled in the sea ice. See Figure 1 for mass/length data. Field-acclimated individuals were sacrificed immediately upon capture. Samples of brain, gill, heart, liver, spleen and white muscle tissue were frozen on liquid nitrogen. Live animals to be used in heat-stress experiments were transported in aerated coolers filled with seawater back to Crary Laboratory at McMurdo Station, maintained by the United States Antarctic Program. Animals were held at $-1.0 \pm 0.5^{\circ} \mathrm{C}$ in flow-through seawater aquaria for a minimum of two days and starved prior to experimentation. 


\section{Heat-stress treatments}

Twenty-four individuals were randomly selected from the holding tank and transferred to one of two re-circulating seawater aquaria held at $2.0^{\circ} \mathrm{C}$ and $4.0^{\circ} \mathrm{C}$. Twelve control fish remained in the holding tank at ambient temperature $\left(-1 \cdot 0 \pm 0.5^{\circ} \mathrm{C}\right)$. For both of the exposure tanks, partial water changes were conducted daily throughout the experiment. Three fish from each temperature treatment $\left(-1.0 \pm 0.5,2.0\right.$ and $\left.4.0^{\circ} \mathrm{C}\right)$ were weighed then killed by cervical transection at 6, 24, 72 and $168 \mathrm{~h}$. Brain, eye, gill, heart, liver, spleen and white muscle tissue was removed and flash-frozen in liquid nitrogen (for western blot) or fixed in 10\% zinc formalin followed by $70 \% \mathrm{EtOH}$ (for IHC). Samples were stored at $-80^{\circ} \mathrm{C}$ (western blot) or $4^{\circ} \mathrm{C}$ (IHC) and shipped to Portland State University for analysis.

\section{PCNA quantification by western blot}

Tissue samples were homogenized in lysis buffer $\left(32 \mathrm{mmol}^{-1} \mathrm{Tris}-\mathrm{Cl}, \mathrm{pH}\right.$ $6.8,0.2 \%$ sodium dodecyl sulfate), boiled for $5 \mathrm{~min}$ at $100^{\circ} \mathrm{C}$ and centrifuged for $12,000 \mathrm{xg}$ for $20 \mathrm{~min}$ at room temperature $\left(\sim 20^{\circ} \mathrm{C}\right.$; RT). Supernates were removed, analyzed for total protein content via the Bradford method and stored at $-80^{\circ} \mathrm{C}$. Fifteen $\mu \mathrm{g}$ total protein were separated by polyacrylamide gel electrophoresis and transferred to nitrocellulose membranes via overnight 
electrotransfer at 30V. Blots were blocked with $1 \times$ PBS $+5 \%$ non-fat dry milk (NFDM) for $1 \mathrm{~h}$ at RT under constant shaking. Blots were incubated in a rabbit polyclonal IgG antibody raised against amino acids 1-261 representing full length human PCNA (sc-7907; Santa Cruz Biotechnology, Santa Cruz, CA, USA) at a dilution of 1:250 in $1 \times$ PBS $+5 \%$ NFDM for $1.5 \mathrm{~h}$ at RT under constant shaking. Primary antibody was removed from blots by $3 \times 10 \mathrm{~min}$ wash in $1 \times$ PBS $+0.1 \%$ Tween-20. Blots were incubated in goat anti-Rabbit IgG conjugated to horseradish peroxidase (Pierce) at a concentration of 1:3000 in 1 $x$ PBS $+5 \%$ NFDM for $1 \mathrm{~h}$ at RT under constant shaking. This secondary antibody was removed from blots by $6 \times 5$ min wash in $1 \times$ PBS $+0.1 \%$ Tween20. Super Signal (Pierce) chemiluminescent substrate was applied to blots for 5 min. Blots were then exposed to X-ray film (XOMAT-AR film, Kodak, Rochester, NY, USA) for between 2 and 24 hours before development of film.

\section{Data analysis and statistics}

Films were scanned and densitometry was conducted using ImageJ software. Background correction was applied and mean pixel intensities were recorded. Data were analyzed in GraphPad Prism software (GraphPad Software, Inc., La Jolla, CA, USA) via Student's $t$ test, one-way ANOVA with 
Tukey's multiple comparison test and two-way ANOVA with Bonferroni posttest.

\section{Relationship between PCNA and body mass}

Body mass data were plotted against PCNA protein concentrations for a total of 18 individuals. Plots were qualitatively scanned for possible relationships between these two variables.

\section{Results}

PCNA levels in field-acclimated Trematomus bernacchii

Data are presented as a proportion (+ standard error) to a liver sample included on all western blots as an internal standard (Fig. 38). Highest protein levels of PCNA were observed in spleen $(6.28 \pm 1.84$ SEM) followed by gill (2.83 \pm 0.80$)$, liver $(0.97 \pm 0.23)$, heart $(0.93 \pm 0.45)$ and brain $(0.11 \pm 0.07)$. No PCNA was detected in white muscle tissue. Tissue type had a highly significant effect on PCNA levels (ANOVA; $p<0.0001$ ). Interindividual variation among animals was almost significant (ANOVA; $p<0.0624$ ). Tukey's multiple comparison test revealed that spleen PCNA was significantly higher than all other tissue types $(p<0.05)$. Gill PCNA was significantly lower than spleen 
but higher than white muscle and brain $(p<0.05)$. Student's $t$ test indicated significant differences between most tissue pairs with the notable exception of heart $(n=3$; Table 1$)$.

\section{PCNA levels in heat-stressed Trematomus bernacchii}

Protein levels and the influence of temperature differed among heart, liver, gill and spleen (Figs. 40-43). PCNA in white muscle and brain tissue were below detectable limits. Neither duration of treatment, temperature nor their interaction had a significant effect on PCNA levels in gill and heart tissue (Table 2). Time had a significant effect on PCNA levels in liver and spleen ( $p=$ $0.0021, p=0.0040)$. There was a significant interaction between time and temperature for liver $(p=0.0266)$, but the effect of this interaction was not quite significant in spleen $(p=0.0546)$. In every tissue analyzed, the $4.0^{\circ} \mathrm{C}$ treatment group reached its maximum PCNA concentration at $24 \mathrm{~h}$. For all tissues except heart, the $2.0^{\circ} \mathrm{C}$ treatment group reached its maximum at $72 \mathrm{~h}$. Heart: No discernable patterns of PCNA were observed across temperature treatments. Protein levels in the $2.0^{\circ} \mathrm{C}$ cohort were qualitatively more stable throughout the time course, while animals held at $-1.0 \pm 0.5$ or $4.0^{\circ} \mathrm{C}$ showed marked fluctuations between adjacent time points (Fig. 39). 
Large interindividual variation was observed of the $-1.0 \pm 0.5^{\circ} \mathrm{C}$ group at $168 \mathrm{~h}$ (Fig. 39).

Liver: PCNA protein concentrations were reduced in heat-stressed fish after $6 \mathrm{~h}$ when compared to control animals held at $-1.0 \pm 0.5^{\circ} \mathrm{C}$ (Fig. 40). This effect was statistically significant for the $2.0^{\circ} \mathrm{C}$ group (Student's $t$ test; $p<0.05$ ), whose PCNA levels then rose above controls to a maximum at $72 \mathrm{~h}$ before falling below controls to an absolute minimum at $168 \mathrm{~h}$. PCNA levels in the $4.0^{\circ} \mathrm{C}$ treatment group rose to an absolute maximum at $24 \mathrm{~h}$, then decreased steadily to just above control levels at $168 \mathrm{~h}$. Animals in the $4.0^{\circ} \mathrm{C}$ and $2.0^{\circ} \mathrm{C}$ treatment groups differed significantly at $168 \mathrm{~h}$ (Students $t$ test; $p<0.01$ )

Gill: Animals held at $2.0^{\circ} \mathrm{C}$ for $6 \mathrm{~h}$ had PCNA levels lower than controls, though this effect was not statistically significant (Fig. 41). These levels rose steadily to a maximum at $72 \mathrm{~h}$ and remained elevated at $168 \mathrm{~h}$. Gill tissue from fish held at $4.0^{\circ} \mathrm{C}$ contained relatively high concentrations of PCNA at 6 and $24 \mathrm{~h}$ and relatively low concentrations at 72 and $168 \mathrm{~h}$. Maximum mean values in the heat-stress treatment groups were accompanied by high interindividual variation. Animals in the $-1.0 \pm 0.5^{\circ} \mathrm{C}$ and $4.0^{\circ} \mathrm{C}$ treatment groups differed nearly significantly at $72 \mathrm{~h}$ (Students $t$ test; $p=0.0578$ ). 
Spleen: Heat stress did not cause an initial decrease in PCNA levels as was observed in gill and liver (Fig. 42). PCNA concentration increased with heat stress between 24 and $72 \mathrm{~h}$ before dropping by as much as 10 -fold by the $168 \mathrm{~h}$ time point. Animals in the $-1.0 \pm 0.5^{\circ} \mathrm{C}$ and $4.0^{\circ} \mathrm{C}$ treatment groups differed significantly at $72 \mathrm{~h}$ (Bonferroni posttest; Student's $t$ test; $p<0.05$ ). Animals in the $-1.0 \pm 0.5^{\circ} \mathrm{C}$ and $2.0^{\circ} \mathrm{C}$ treatment groups also differed significantly (Student's $t$ test; $p<0.05$ ). All treatment groups contained similarly low concentrations of PCNA protein at the $168 \mathrm{~h}$ time point.

\section{Relationship between PCNA and body mass}

Body mass data were available for 18 specimens of T. bernacchii held at $1.0 \pm 0.5,2.0$ or $4.0^{\circ} \mathrm{C}$ for 72 or $168 \mathrm{~h}$. These data were compared to PCNA protein concentrations measured in heart, liver, gill and spleen (Figs. 43-45). Positive correlations between these two variables were observed in gill ($1.0 \pm 0.5^{\circ} \mathrm{C}$ treatment group; Fig. 43$)$, liver and spleen $\left(4.0^{\circ} \mathrm{C}\right.$ treatment group; Fig. 45). Negative correlations were observed in spleen $\left(-1.0 \pm 0.5^{\circ} \mathrm{C}\right.$ treatment group; Fig. 43) and gill $\left(4.0^{\circ} \mathrm{C}\right.$ treatment group; Fig. 45). PCNA expression profiles for heart and spleen are similar at $-1.0 \pm 0.5^{\circ} \mathrm{C}$, but they are inverted at $4.0^{\circ} \mathrm{C}$. Heart and gill are inverted at $2.0^{\circ} \mathrm{C}$, but they are similar at $4.0^{\circ} \mathrm{C}$. Liver 
and spleen trend together at $2.0^{\circ} \mathrm{C}$. Because the significance of these data is unclear, they were excluded from further, more formal analyses.

\section{Relationship between PCNA and C/EBP-delta concentration}

C/EBP-delta and PCNA concentrations were compared in spleen tissue from 36 specimens of T. bernacchii (Figs. 46-47). A positive correlation was observed between the two variables in control fish held at $-1.0 \pm 0.5^{\circ} \mathrm{C}$ (Fig. 46). No correlation was observed between C/EBP-delta and PCNA concentrations in heat-stressed T. bernacchii (Fig. 47).

\section{Discussion}

Cell cycle control and apoptosis are two important aspects of the cellular stress response (Kültz, 2005); however, whether and how these processes are modulated during environmental stress is unclear and understudied. This is especially true when it comes to the extremely coldadapted and stenothermal fishes of Antarctica, for which I have previously demonstrated the heat induction of a known regulator of cell cycle arrest and apoptosis, namely, C/EBP- $\delta$ (Sleadd and Buckley, 2013; Chapter 2). To investigate whether heat induction of this transcription factor reflects a 
cessation of the cell cycle in an Antarctic fish species, I measured relative protein concentrations of PCNA, a common marker of cell proliferation, in field-acclimated and heat-stressed Trematomus bernacchii.

\section{Constitutive levels of PCNA in field-acclimated T. bernacchii}

PCNA was present in untreated, field-acclimated T. bernacchii, indicating constitutive cellular proliferation and turnover. Relative abundance of this protein varied among tissue types (Fig. 38, table 1). Intriguingly, this tissue specificity matches that observed for ubiquitin-conjugated proteins in $T$. bernacchii (Todgham et al., 2007; Fig. 3 therein), suggesting a possible link between PCNA expression and protein degradation. In that study examining four tissue types in seven fish species, the highest levels of ubiquitinconjugates were found in spleen from T. bernacchii and in the eelpout Lycodichthys dearborni (Todgham et al., 2007; Fig. 3 therein). In the present study, this tissue type contained the highest levels of PCNA, suggesting the greatest degree of cellular turnover may be found in this organ. In addition to serving as a site for erythrocyte storage and processing, the spleen also acts as an erythropoietic center in some, but not all, species of teleost fish (Fänge and Nilsson, 1985; Wells and Weber, 1990, and references therein). A histological 
study by Romano et al. (1997) described the T. bernacchii spleen as being mostly erythropoietic, suggesting that the high levels of splenic PCNA observed here may be due in part to the manufacturing of red blood cells. There are also small patches of lymphoid tissue present in the T. bernacchii spleen, indicating that leukopoietic processes may also be reflected in these PCNA data.

Western blot analysis detected no PCNA protein in white skeletal muscle, as predicted based on the large amounts of anti-proliferative C/EBP- $\delta$ present in this tissue type (Sleadd and Buckley, 2013; Chapter 2). This lack of PCNA may also be due in part to the relatively low concentrations of nuclei in white muscle tissue. Brodeur et al. (2002) reported that for Harpagifer antarcticus and bispinis, $75 \%$ of myogenic progenitor cells were in a proliferative state. Therefore, PCNA immunohistochemistry (IHC) may be a more sensitive technique for assessing cell cycle progression in muscle tissue.

\section{PCNA in heat-stressed T. bernacchii}

Western blotting was used to determine relative levels of PCNA protein in six tissues from T. bernacchii held at $-1.0 \pm 0.5,2.0$ or $4.0^{\circ} \mathrm{C}$ for up to one week (Figs. 39-42). As was seen in field-acclimated individuals, heat- 
stressed animals displayed striking tissue specificity in PCNA expression. Two-way ANOVA revealed that time had a significant effect on PCNA levels in liver and spleen tissue, and the interaction between time and temperature was also significant in these organs (Table 2). I hypothesized that cellular proliferation would decrease in response to heat stress in order to provide for the allocation of maximum resources towards cytoprotection. However, the only decrease in PCNA values that I observed was in liver tissue from heatstressed individuals at the $6 \mathrm{~h}$ time point (Fig. 40). This may reflect an initial slowing or dysregulation of the cell cycle in this tissue type, which may then lead to a reactionary increase in PCNA levels apparent at $24 \mathrm{~h}$ and to a lesser extent at $72 \mathrm{~h}$.

Contrary to my predictions, heat stress appears to have caused an increase PCNA expression in all tissues except heart. Mean PCNA levels for the $4.0^{\circ} \mathrm{C}$ cohort always reached a maximum at $24 \mathrm{~h}$. In all tissues except heart, mean PCNA levels for the $2.0^{\circ} \mathrm{C}$ cohort reached a maximum at $72 \mathrm{~h}$. This staggered response based on treatment temperature is most evident in gill (Fig. 41) but is also apparent in liver (Fig. 40) and spleen (Fig. 42). Significant increases in PCNA concentration were recorded for spleen at the $72 \mathrm{~h}$ time point in heat-stressed individuals (Fig. 42). If T. bernacchii spleen is indeed an 
erythropoietic organ, this may reflect an increase in red blood cell production in response to increased oxygen demand. T. bernacchii is known to dump splenic stores of erythrocytes into the circulation following exercise, heat stress $\left(10^{\circ} \mathrm{C}\right)$ and hypoxia, thereby increasing hematocrit by up to $160 \%$ (Davison et al., 1994). However, T. bernacchii held at $4.0^{\circ} \mathrm{C}$ for two weeks or one month did not possess elevated hematocrit or cortisol levels (Hudson et al., 2008), suggesting that any haematological response is acute and transitory. The PCNA response observed in the present study is short-lived, with heatstressed fish being indistinguishable from controls after $168 \mathrm{~h}$. It is tempting to speculate that the observed increase in splenic PCNA during the first $72 \mathrm{~h}$ is contributing to the de novo production of red blood cells, which may remain stored in the spleen, thus accounting for the lack of change in hematocrit (Hudson et al., 2008) and perhaps contributing to the inducible heat tolerance of T. bernacchii (Podrabsky and Somero, 2006).

Total cell cycle duration time for an Antarctic fish species has been reported as $111 \mathrm{~h}$ for myogenic progenitor cells with an S-phase of $37 \mathrm{~h}$ (Brodeur et al., 2003a). These durations are approximately five times longer than those of human cells, so one may estimate that G1 would last ca. 50 h, G2 would last ca. $20 \mathrm{~h}$ and mitosis would be on the order of $5 \mathrm{~h}$. If these times are 
similar in all T. bernacchii cell types, then the drop in PCNA levels observed after $6 \mathrm{~h}$ of heat stress in liver-and perhaps gill-is almost certainly be maladaptive, as it indicates the large-scale degradation of PCNA protein in the midst of S-phase. Elevated PCNA concentrations after $24 \mathrm{~h}$ suggest an increase in the number of cells undergoing S-phase at that time. These cells would have to have been in late G1/G0 at the beginning of the experiment, ready to proliferate in order to contribute to hypertrophy or restructuring of the organs in question. Alternatively, it is also possible that PCNA is pathologically overexpressed in heat-stressed T. bernacchii, in which case the relationship between cell proliferation and PCNA concentration would be lost. This is observed in certain mammalian neoplasms and their adjacent, morphologically normal tissues (Hall et al., 1990).

\section{Transcriptional regulation of $P C N A$}

While the promotor for PCNA in T. bernacchii has not yet been sequenced, the human PCNA promoter contains putative binding sites for well over a dozen transcription factors (Paunesku et al., 2001). Many of these are heat-sensitive in aquatic ectotherms. Oncogene responsive polyoma enhancer activator 2 (Pea3) and tumor suppressor p53 are heat-inducible in 
the Lemon Damselfish, Pomacentrus moluccensis, while GATA2 and C/EBP- $\delta$ are both downregulated in response to heat stress in this species (Kassahn et al., 2007). In the goby Gillichthys mirabilis, Elk-1 (member of protooncogene family ets), cAMP responsive element binding protein 2 (CREB2), activating

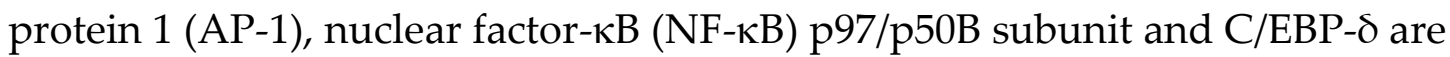
all heat-inducible (Buckley et al., 2006). AP-1 is down-regulated with cold acclimation in the common carp (Gracey et al., 2004), and c-fos (a member of the AP-1 heterodimer) is also down-regulated with cold acclimation in the Pacific bluefin tuna Thunnus orientalis (Catilho et al., 2009). The latter study also showed a downregulation of $\mathrm{C} / \mathrm{EBP}-\delta$ and an upregulation of the negative $\mathrm{C} / \mathrm{EBP}$ regulator, $\mathrm{C} / \mathrm{EBP}-\zeta$, in cold-acclimated $T$. orientalis. CREB-like protein 2, $\mathrm{C} / \mathrm{EBP}-\varepsilon$ and $\mathrm{C} / \mathrm{EBP}-\gamma$ are heat-inducible in the mussel Mytilus californianus (Gracey et al., 2008), and the general transcription factor IID (TFIID) is heatinducible in the porcelain crab Petrolisthes cinctipes (Teranishi and Stillman, 2007). C/EBP- $\beta$ is upregulated in the heat-stressed anemone Anthopleura elegantissima (Richier et al., 2008), but downregulated in response to heat stress in the coral Montastraea faveolata (Desalvo et al., 2008). C/EBP- $\alpha$ is downregulated in heat-stressed A. elegantissima (Richier et al., 2008). Of particular relevance to the present study, C/EBP- $\delta$ and C/EBP- $\beta$ are both heat- 
inducible in the Antarctic fish Trematomus bernacchii (Buckley and Somero, 2009; Sleadd and Buckley, 2013).

Taken together, these results indicate that the promotor region of PCNA is a highly dynamic and stress-responsive regulatory region in aquatic ectotherms.

$P C N A$ and $C / E B P-\delta$ concentration

C/EBP- $\delta$ and PCNA concentrations were compared in splenic tissue from 36 specimens of T. bernacchii (Figs. 46-47). A positive relationship was observed between the two variables in control fish held at $-1.0 \pm 0.5^{\circ} \mathrm{C}$ (Fig. 46). This is surprising given that C/EBP- $\delta$ is generally regarded as antiproliferative; however, it is possible that this transcription factor is helping to increase PCNA expression by binding to its putative promotor sequence (see previous section). No relationship was observed between C/EBP- $\delta$ and PCNA concentrations in heat-stressed T. bernacchii (Fig. 47).

\section{Concluding remarks}

The results presented here suggest that a mild, sub-lethal heat stress can affect cell proliferation in the Antarctic fish Trematomus bernacchii. This is likely to be deleterious in the case of liver and perhaps gill, which show a 
decrease in PCNA protein concentration after only $6 \mathrm{~h}-$ a short amount of time compared to cell cycle durations described in a previous study (Brodeur et al., 2003a). In most tissue types, cell proliferation appears to increase in response to heat stress within $72 \mathrm{~h}$ and return to control levels by $168 \mathrm{~h}$. This is in apparent contradiction with my observations that the anti-proliferative transcription factor C/EBP- $\delta$ is heat inducible in T. bernacchii. While PCNA is for the most part a reliable index of DNA synthesis, there remains the possibility that PCNA may be pathologically over-expressed in thermally stressed individuals and that PCNA does not accurately represent rates of cell division. Future work is needed to elucidate the precise mechanisms underlying the heat-responsiveness of PCNA in ectotherms in general, and $T$. bernacchii in particular. 


\title{
Chapter 5: Flow-cytometry analysis of cell cycle and apoptosis in heat-stressed Trematomus bernacchii hepatocytes
}

\begin{abstract}
Antarctic fishes have the lowest upper thermal maxima of any animal. A recent cDNA microarray study identified scores of heat-responsive genes in the common Antarctic fish Trematomus bernacchii. Among these are known regulators of apoptosis and the cell cycle--two important determinants of stress tolerance whose contributions are understudied. To determine the heatsensitivity of cell proliferation and apoptosis in T. bernacchii, I used flow cytometry to determine cell cycle stages in isolated hepatocytes held at a range of temperatures from -2 to $10^{\circ} \mathrm{C}$ for up to $24 \mathrm{~h}$. Increased temperatures led to greater proportions of hepatocytes undergoing apoptosis. This effect was significant at temperatures as low as $6^{\circ} \mathrm{C}$, which is the boundary temperature between sublethal and lethal for this species. The increase in apoptotic cells was mirrored by a decrease in G1 cells, suggesting that cells in G1/G0--and not G2 or S-phase--were committing to apoptosis.
\end{abstract}




\section{Introduction}

Organisms combat various environmental perturbations through the taxonomically well conserved cellular stress response (CSR). The CSR involves stabilizing and repairing macromolecules, redox sensing and regulation, cell cycle control and adaptive shifts in metabolism, with the end goal of maintaining homeostasis (for review see Kültz, 2005). When these mechanisms fall short, apoptotic cell death is a likely consequence. Even a cursory review of the literature reveals that protein chaperoning via the upregulation of heat shock proteins (Hsps) has garnered the most attention of all the aforementioned "hallmarks" of the CSR (Feder and Hofmann, 1999). In contrast, an organism's ability to modulate cellular proliferation remains a relatively unexplored strategy for coping with environmental stress. By temporarily halting progression through the cell cycle, an animal would be able to allocate energy away from growth and towards the maintenance of macromolecular integrity. If and when a stress subsides, the organism may then exit the CSR and resume normal cellular growth and proliferation. 
Perhaps not surprisingly, most investigations into the CSR focus on aquatic ectotherms whose body temperatures fluctuate with environmental temperatures. Organisms living nearest their thermal maxima possess limited capacity for thermal acclimation and are therefore considered to be the most vulnerable to anthropogenic climate change (Somero, 2010). These organisms include the Antarctic notothenioid fishes, whose evolution in the extreme and stable cold has rendered them highly stenothermal (Eastman, 1993). Upper thermal maxima for these animals are the lowest on record $\left(6^{\circ} \mathrm{C}\right.$; DeVries and Somero, 1967), and their inability to upregulate Hsps speaks to a highly unusual CSR (Hofmann et al., 2000; Buckley et al., 2004; Buckley and Somero, 2009). The absence of an inducible heat shock response raises the possibility that another unknown mechanism(s) exists for coping with temperature's pervasive effects on biological structure and function.

A recent cDNA microarray study revealed broad transcriptomic changes in response to heat stress in the common notothenioid Trematomus bernacchii (Buckley and Somero, 2009). This was the first study to demonstrate in an Antarctic fish the ability to alter gene expression in response to thermal stress. Building on those results, I showed that protein levels of CCAAT/Enhancer-binding protein delta - a transcription factor associated 
with cell cycle arrest and apoptosis - is heat inducible in T. bernacchii (Chapter 2; Sleadd and Buckley, 2013). Proliferating cell nuclear antigen also displays heat sensitivity in $T$. bernacchii, suggesting that cell cycle modulation may be a consequence of or an adaptive response to environmental stress in this species (Chapter 4). To further investigate temperature's effects on cell cycle progression in Antarctic stenotherms, the present chapter utilizes flow cytometry to determine cell cycle stage and apoptosis for T. bernacchii hepatocytes subjected to a varying degrees of thermal stress. I found that sublethal temperatures $\left(2-4^{\circ} \mathrm{C}\right)$ cause cells to undergo an initial G1 growth arrest followed by subsequent initiation of apoptosis at later time points. At higher temperatures $\left(6-10^{\circ} \mathrm{C}\right)$ that are lethal to the intact organism, cells commit to apoptosis sooner--a condition which may contribute to the upper thermal maximum of T. bernacchii and other Antarctic fishes.

\section{Methods}

\section{Animals}

Specimens of Trematomus bernacchii were collected by hook and line through holes drilled in the sea ice of McMurdo Sound during the 2011 and 
2012 austral summers. Fishing locations included Inaccessible Island, Cape Evans, Cape Evans Wall and the jetty near McMurdo Station. Fish were transported in aerated coolers back to the United States Antarctic Program's Crary Laboratory where they were maintained at ambient temperature ($1.0 \pm 0.5^{\circ} \mathrm{C}$ ) in flow-through seawater aquaria. The animals were starved and laboratory acclimated for at least $48 \mathrm{hrs}$ prior to experimentation. Hepatocyte isolation and preparation $N=6$ animals were euthanized in $-1.0 \pm 0.5^{\circ} \mathrm{C}$ seawater containing $0.1 \%$ MS-222. Livers were perfused through the hepatic portal vein with $-1.86 \pm 0.5^{\circ} \mathrm{C}$ perfusion buffer solution containing $290 \mathrm{mM} \mathrm{NaCl}, 2 \mathrm{mM} \mathrm{KCl}, 0.5 \mathrm{mM}$ EGTA, $25 \mathrm{mM}$ tricene, and $10 \mathrm{mM}$ HEPES. Livers were excised and minced. The tissue was placed on a rotator for one hour on ice in cell suspension buffer containing $292.5 \mathrm{mM} \mathrm{NaCl}, 5 \mathrm{mM} \mathrm{KCl}, 2.5 \mathrm{mM} \mathrm{MgCl} 2,3 \mathrm{mM} \mathrm{CaCl}, 2 \mathrm{mM}$ $\mathrm{NaHCO}_{3}, 2 \mathrm{mM} \mathrm{NaH} 2 \mathrm{PO}_{4}, 5 \mathrm{mM}$ glucose, 50 mM HEPES, with 5 units $\mathrm{ml}^{-1}$ collagenase added to dissociate the hepatocytes. Liver samples were mechanically forced through a cell dissociation sieve fitted with size 50 and 200 mesh (Sigma-Aldrich ${ }^{\circledR}$ ). Cells were pelleted by centrifugation, washed twice, and brought to a concentration of $1-2 \times 10^{6}$ cells ml-1 in ice-cold cell suspension buffer. 


\section{Temperature treatments}

Hepatocytes in cell suspension buffer were held in $1.5 \mathrm{ml}$ centrifuge tubes for the remainder of the experiment. These tubes, left open for aeration, were floated in recirculating water baths held at $0,2,4,6$ or $10^{\circ} \mathrm{C}$ for up to 24 h. Hepatocytes were occasionally aerated by transfer pipette. At each time point $(0,2,4,8,12,24 \mathrm{~h})$, approximately one million cells (in $1 \mathrm{ml}$ suspension buffer) were pelleted by gentle centrifugation and brought up in ice-cold 70\% $\mathrm{EtOH}$ and stored at $-20^{\circ} \mathrm{C}$. Some hepatocytes were also prepared during the 2011 field season for TUNEL analysis according to manufacturer's directions (Apo BrdU, PhoenixFlow Systems). Upon completion of the experiment, cells in EtOH were shipped at $4-6^{\circ} \mathrm{C}$ back to Portland State University in Oregon. Cells for use in TUNEL analysis were inadvertently shipped on dry ice (ca. $\left.70^{\circ} \mathrm{C}\right)$

\section{Cell cycle and TUNEL analysis by flow cytometry}

A protocol for determining cell cycle stages and apoptosis by flow cytometry was adapted from Darzynkiwicz et al. (1992, 1999). Hepatocytes were pelleted by gentle centrifugation, washed twice in ice-cold 1 X PBS and resuspended in staining solution consisting of $0.1 \%(\mathrm{v} / \mathrm{v})$ Triton $\mathrm{X}-100+0.02 \%$ Dnase-free RNase A $+0.005 \%$ propidium iodide (PI) in ice-cold $1 \mathrm{X}$ PBS. Cells 
were stained for $30 \mathrm{~min}$ on ice and analyzed on a BD Accuri ${ }^{\mathrm{TM}}$ C6 Flow Cytometer. TUNEL assays were performed according to manufacturer's instructions (PhoenixFlow Systems).

\section{Data analysis and statistics}

Data were collected and analyzed with C6 software (BD Accuri $\left.{ }^{\mathrm{TM}}\right)$.

Gates were drawn around populations of cells based upon their DNA content (PI fluorescence) in order to distinguish different cell cycle stages. Doublet discrimination was carried out to minimize the influence of cell clumping. Proportions of total cell counts were recorded for each cell cycle stage and statistical analyses were performed using GraphPad Prism software (GraphPad Software, Inc., La Jolla, CA, USA). Proportions were treated with arcsin-squareroot transformations prior to use in two-way ANOVAs and Bonferroni post-tests.

\section{Results}

Cell cycle stage and apoptosis in heat-stressed T. bernacchii hepatocytes were determined by cellular DNA content (Figure 48-49) in order to investigate the potentially important role of cell fate determination in this 
organism's unique CSR. Temperature had a significant effect on the proportions of cells in each stage of the cell cycle, as well as the proportions of hepatocytes undergoing apoptotic cell death (Figs. 48-49).

\section{G1 phase}

Numbers of hepatocytes in the G1 phase of the cell cycle ranged from a minimum of $62.2 \pm 0.8 \%$ SEM (measured at $12 \mathrm{~h}, 10^{\circ} \mathrm{C}$ ) to a maximum of $77.9 \pm 1.1$ (measured at $8 \mathrm{~h}, 0^{\circ} \mathrm{C}$ ). Duration of treatment had a significant effect on hepatocyte number (two-way ANOVA; $F=8.349, p<0.0001$ ), but temperature did $\operatorname{not}(F=1.066 ; p=0.3943)$. There was also a significant interaction between time and temperature $(F=5.502 ; p<0.0001)$. Bonferroni posttests revealed no significant differences between $-2,0$ and $2^{\circ} \mathrm{C}$ temperature treatments at any time point. At $12 \mathrm{~h}$, the $-2^{\circ} \mathrm{C}$ treatment group contained significantly more G1 cells than the $10^{\circ} \mathrm{C}$ treatment group $(p<0.05)$. At $24 \mathrm{~h}$, the $-2^{\circ} \mathrm{C}$ treatment group contained significantly more $\mathrm{G} 1$ cells than both the 6 and $10^{\circ} \mathrm{C}$ treatment groups ( $p<0.05$ and $p<0.01$, respectively). The $0^{\circ} \mathrm{C}$ treatment group showed precisely the same statistical relationship with 6 and $10^{\circ} \mathrm{C}$ treatment groups. 


\section{S phase}

Duration of treatment, but not temperature or the interaction between these two variables, had a significant effect on the percentage of T. bernacchii hepatocytes undergoing $S$ phase (two-way ANOVA; $F=12.64 ; p<0.0001$ ). This percentage ranged from a minimum of $8.8 \pm 1.0 \%$ SEM (measured at $24 \mathrm{~h},-2^{\circ} \mathrm{C}$ ) to a maximum of $17.8 \pm 1.7$ (measured at $2 \mathrm{~h}, 2^{\circ} \mathrm{C}$ ). Bonferroni posttests revealed no significant differences between treatments.

\section{G2 phase}

Duration of treatment, but not temperature or interaction between these two variables, had a significant effect on the percentage of T. bernacchii hepatocytes in G2 phase of the cell cycle (two-way ANOVA; $F=12.06 ; p<$ 0.0001). This ranged from a minimum of $8.7 \pm 0.9 \%$ SEM $\left(24 \mathrm{~h}, 6^{\circ} \mathrm{C}\right)$ to a maximum of $13.7 \pm 2.0\left(2 \mathrm{~h},-2^{\circ} \mathrm{C}\right)$. Bonferroni posttests revealed no significant differences between treatments.

\section{Apoptotic cells}

Apoptotic cells appeared as a pre-G1 peak or shoulder in cellular DNA fluorescence (Figure 48). Duration of treatment had a significant effect on the proportion of T. bernachii hepatocytes undergoing apoptosis (two-way 
ANOVA; $F=94.39 ; p<0.0001)$, as did temperature $(F=19.78 ; p<0.0001)$ and interaction between these two variables $(F=10.02 ; p<0.0001)$. TUNEL assays, on the other hand, revealed no significant differences between treatments (data not shown). Percentage of total cells that were apoptotic ranged from a minimum of $1.0 \pm 0.2 \% \operatorname{SEM}\left(4 \mathrm{~h}, 0^{\circ} \mathrm{C}\right)$ to a maximum of $18.8 \pm 8.3\left(24 \mathrm{~h}, 10^{\circ} \mathrm{C}\right)$. Bonferroni posttests revealed no significant differences between $-2,0$ and $2{ }^{\circ} \mathrm{C}$ treatment groups, with the exception of 0 versus $2^{\circ} \mathrm{C}$ after $24 \mathrm{~h}(p<0.05)$. Hepatocytes held at $-2^{\circ} \mathrm{C}$ were less likely to be apoptotic than cells held at $6^{\circ} \mathrm{C}$ $(8,12$ and $24 \mathrm{~h}$ time points; $p<0.01)$. The $-2,0$ and $2^{\circ} \mathrm{C}$ treatment groups each showed significantly fewer apoptotic cells than the $10^{\circ} \mathrm{C}$ treatment group at 4 , 8,12 and $24 \mathrm{~h}$ time points $(p<0.001)$. Significant differences were observed between 0 and $6^{\circ} \mathrm{C}$ treatments at 8,12 and $24 \mathrm{~h}(p<0.01)$, between 2 and $6^{\circ} \mathrm{C}$ treatments at 12 and $24 \mathrm{~h}(p<0.5)$ and between 6 and $10^{\circ} \mathrm{C}$ treatments at 4,8 and $12 \mathrm{~h}(p<0.05)$. In all these cases, the higher temperature treatment group contained a greater proportion of apoptotic cells. 


\section{Discussion}

Cell cycle stage and apoptosis were determined for isolated T. bernacchii hepatocytes for the purpose of investigating whether environmental heat stress leads to apoptosis and/or cell cycle arrest in these cold-adapted stenotherms. Temperature and duration of temperature treatment have significant effects on cell cycle stage and apoptosis in isolated Trematomus bernacchii hepatocytes (Figs. 48-49). At the $2 \mathrm{~h}$ time point, when apoptosis is minimal, the proportion of cells in G1or S phase appears to be inversely affected by heat stress. For the lower temperature treatment groups $(-2,0$ and $2^{\circ} \mathrm{C}$ ), the percentage of cells in G1 or S phase are at their lowest and highest, respectively, at this first time point, perhaps indicating an initial resumption of DNA synthesis and proliferation upon recovery from the stresses associated with mechanical and chemical dissociation from the intact organ in vivo. However, it seems unlikely that cell cycle arrest could be so quickly engaged and then retracted in these cells. Human fibroblasts, for comparison, undergo a $24 \mathrm{~h}$ cessation of the cell cycle (halted at G1/S) in response to $45 \mathrm{~min}$ at $43^{\circ} \mathrm{C}$ (Okamura et al., 1997). In the event of an arrest at the G1/S checkpoint, increased temperatures may speed the passage through S, G2 and M phases. Brodeur et al. (2003a) reported a cell cycle duration of $150 \mathrm{~h}$ for the sub- 
Antarctic plunderfish Harpagifer bispinis held at $5^{\circ} \mathrm{C}$, and $81.3 \mathrm{~h}$ for animals held at $10^{\circ} \mathrm{C}$, which yields a Q10 temperature coefficient of 3.4.

Between $-2^{\circ} \mathrm{C}$ and higher temperature treatment groups there is an apparent drop in the number of hepatocytes undergoing $S$ phase at $4 \mathrm{~h}$, and to a lesser extent $8 \mathrm{~h}$ (Fig. 49). This seems to fit with the in vivo data from chapter 4 of this dissertation, which demonstrated a decrease in PCNA protein levels after $6 \mathrm{~h}$ at either 2 or $4^{\circ} \mathrm{C}$ (Fig. 40). Despite a subsequent increase in PCNA protein concentrations after $24 \mathrm{~h}$, no changes were observed in the proportion of S-phase hepatocytes as determined by flow cytometry in the present chapter.

Especially at 8 and $12 \mathrm{~h}$, the proportion of cells in G1 drops off sharply between 6 and $10^{\circ} \mathrm{C}$ treatment groups, indicating a threshold between these temperatures. By $24 \mathrm{~h}$, this threshold has moved to between 0 and $2^{\circ} \mathrm{C}$. Such "tipping points" are not as evident when looking at apoptotic cells, which display a more graded response to heat stress, with the possible exception of the $24 \mathrm{~h}$ time point. Whereas S-phase and G1 data were inversely proportionate to one another at the $2 \mathrm{~h}$ time point, at later time points it is the apoptotic cells which best mirror the G1 populations. Since temperature has little if any effect on the proportion of hepatocytes in G2 or S-phase at the $24 \mathrm{~h}$ 
time point, it is G1 cells primarily that are committing to apoptosis at the higher treatment temperatures.

Perhaps one of the most interesting findings presented here is that potentially sub-lethal temperatures can lead to a significant increase in the number of apoptotic hepatocytes in T. bernacchii. The upper thermal maximum (LT50) is 6 or $7^{\circ} \mathrm{C}$ for these and other Antarctic fishes (Somero and DeVries, 1967). The highest temperature at which these animals can acclimate for long periods of time is near $4^{\circ} \mathrm{C}$. These flow cytometry data indicate that these temperatures are sufficient to cause apoptosis of hepatocytes in vitro. Efforts to measure apoptosis in vivo via TUNEL immunohistochemistry proved inconclusive (Chapter 3). Either there were no apoptotic hepatocytes in the animals investigated--meaning that levels were naturally very low and heat stress had no effect--or, alternatively, inadequate preparation and handling of samples rendered the methods ineffective. It is not currently known what exactly causes heat death in these extremely cold-adapted stenotherms. The lack of an inducible upregulation of Hsps points to the potential lethality of protein misfolding and aggregation. The temperature sensitivity of lipid bilayers raises the possibility of neurovesicular melting and the accompanying neurotransmitter deregulation. The data presented here, which demonstrate 
that temperatures which are sublethal to the intact organism can be lethal to isolated cells, should help to pinpoint the precise cause(s) of thermal death in Antarctic fishes.

One of the goals of this dissertation was to correlate the expression of C/EBP- $\delta$ with cell cycle and apoptosis data; however, this protein was never detected in liver tissue in T. bernacchii. It is possible that, although this protein is below detectable limits in this tissue type, it is still physiologically active. Another possibility involves its isoform, C/EBP- $\beta$ : These two members of the C/EBP family have some functional redundancy as evidenced by knockout studies, and C/EBP- $\beta$ was also found to be heat-sensitive in T. bernacchii (Buckley and Somero, 2009). Future studies may investigate the roles of this closely related transcription factor in heat-stressed teleost hepatocytes. 


\section{Chapter 6: The new synthesis: a modified stress response in Antarctic fishes}

The work described in this dissertation began with three initial hypotheses concerning environmental stress, transcriptional regulation and cell fate determination. Data presented in the previous chapters partially confirm these hypotheses, thereby necessitating a new integrated model of the cellular stress response in extremely cold-adapted organisms.

Initial hypothesis 1) Apoptosis and cell cycle arrest may be important components of the cellular stress response (CSR) in polar organisms When researchers first discovered that the heat shock response (HSR) is absent in the Antarctic fish Trematomus bernacchii (Hofmann et al., 2000), it was cause for excitement. Until then, the ability to respond to environmental heat stress by increasing protein concentrations of the heat shock protein (Hsp) family of molecular chaperones was thought to be nearly ubiquitous in nature, with the notable exception of the freshwater Hydra oligactis (Bosch et al., 1988). This new research on T. bernacchii raised a number of questions and hypotheses. First and foremost, it soon became widely accepted that this lack 
of a functioning HSR was a crucial determinant of species' upper thermal maxima, which in Antarctic fishes are exceptionally low $\left(6-7^{\circ} \mathrm{C}\right.$; Somero and DeVries, 1967). This line of thought had the unintended consequence of suggesting that these animals lack any and all capacity for responding adaptively to environmental heat stress. We now know from a number of studies that this premise is false (e.g., Podrabsky and Somero, 2006; Buckley and Somero, 2009; Bilyk and DeVries, 2011), but the cellular events which underpin warm acclimation of the intact organism are very poorly defined in these fishes. The question stands: If Antarctic fishes have no HSR, then what other cellular mechanisms exist for combatting thermal stress? Two prime candidates are cell cycle arrest and apoptosis.

Kültz (2005) described four key functions of the conserved cellular stress response (CSR): 1) maintenance of macromolecular integrity (e.g., via Hsps), 2) energy metabolism, 3) apoptosis and 4) growth control and cell cycle checkpoints. Because the upregulation of Hsps is absent in Antarctic fishes, we must look to the understudied mechanisms (particularly 3 and 4 ) if we are to delineate the uniquely modified CSR in these environmentally sensitive species. One challenge is the glaring descrepancies in the amount of research attention given to each of the above "hallmarks" of the CSR. A PubMed search 
for heat shock proteins and environmental stress yields 370 hits, compared to 24 hits for cell cycle arrest and environmental stress. We therefore have extensive knowledge of Hsps and molecular chaperoning, but minimal understanding of the other CSR functions mentioned above. To reduce this knowledge gap, I tested the overarching hypothesis that cell cycle arrest is a means by which Antarctic fishes may response adaptively to environmental heat stress. By diverting energy away from cellular proliferation and towards cytoprotective machinery, an individual cell may increase its chances of survival (avoiding apoptosis in the process). This strategy, and the molecular pathways responsible, may exert bottom-up effects upon the fitness of the entire organism with implications in evolutionary and biogeographic responses to anthropogenic climate change. Recent cDNA microarray studies have set an excellent stage for investigations into these matters by identifying dozens of heat-responsive genes with known roles in the mediation of cell cycle arrest and apoptosis. 
Initial hypothesis 2) The CCAAT/Enhancer-binding protein delta (C/EBP- $\delta)$ transcription factor is heat-inducible in Antarctic fishes

Using cDNA microarrays, ecophysiologists have investigated the effects of temperature, UV stress, salinity stress, hypoxia, and toxic metal exposure on the transcriptomes of several marine species. Hundreds of genes are differentially regulated during environmental stress, and these play diverse roles in a wide array of physiologic processes. Some of the most intriguing findings to come from these studies are the recurrent observations that the CCAAT/Enhancing-binding protein (C/EBP) family of eukaryotic transcription factors is heat-sensitive in poikilothermic animals. In fact, each of the six C/EBP family members is temperature-sensitive in at least one species (Buckley et al., 2006; Kassahn et al., 2007; Desalvo et al., 2008; Gracey et al., 2008; Richier et al., 2008; Buckley and Somero, 2009; Castilho et al., 2009). One of these, C/EBP- $\delta$, was strongly heat-induced in the intertidal goby Gillichthys mirabilis not only at the mRNA level (Buckley et al., 2006), but at the protein level as well (Buckley, 2011). Consistent with those results, cold-adaptation in bluefin tunas (Thunnus orientalis) led to a decrease in C/EBP- $\delta$ mRNA levels with a concomitant increase in the inhibitory family member $\mathrm{C} / \mathrm{EBP}-\zeta$ 
(Castilho et al., 2009); however, in the tropical damselfish Pomacentrus moluccensis, heat caused a down-regulation of C/EBP- $\delta$ at the mRNA level (Kassahn et al., 2007), suggesting that heat-induction of this gene is not common to all fishes. Because in most cases C/EBP- $\delta$ is upregulated in response to heat stress, I hypothesized that this would also be the case in the Antarctic fish T. bernacchii. If this hypothesis were to be supported by demonstrating that $\mathrm{C} / \mathrm{EBP}-\delta$ protein concentrations increase in response to heat stress in these cold-adapted stenotherms, it would have important implications in understanding these animals' unique CSR. The C/EBP- $\delta$ transcription factor is especially interesting because it plays a clear role in cell cycle arrest and a less clear role in apoptosis. As stated earlier, these two processes are understudied when it comes to the ecophysiology of poikilotherms. Given the lack of an inducible HSR in T. bernacchii and other polar organisms, cell fate determination in the face of environmental stress is a very promising line of inquiry.

Much of what we know about the roles of C/EBP- $\delta$ in cell cycle control and apoptosis comes from biomedical research on mammalian study systems. It is consistently associated with cell cycle arrest in the literature. For instance, it is silenced in acute myeloid leukemia (Agrawal, 2007), and the forced 
expression of this gene can inhibit the growth of certain cancers (Ikezoe et al., 2005). Therefore, if C/EBP- $\delta$ is acting as a "brake" on cell division in heatstressed Antarctic fishes, this transcription factor may prove to be a key player in these organisms' modified CSR--a mechanism which lacks an inducible HSR.

Initial hypothesis 3) If hypotheses 1 and 2 are supported, perhaps $C / E B P-\delta$ is correlated with cell cycle arrest in Antarctic fishes

If cell cycle arrest is indeed favored in the unique CSR of Antarctic fishes, and if the C/EBP- $\delta$ transcription factor is heat-inducible in these animals, then these two processes may be correlated. As mentioned above, numerous biomedical studies have demonstrated direct mechanistic links between C/EBP- $\delta$ and cell cycle arrest. As a transcription factor, the DNAbinding activity of $\mathrm{C} / \mathrm{EBP}-\delta$ is presumably important, and scores of downstream target genes have been identified in growth-arrested mammary epithelial cells (Zhang et al., 2008). That being said, C/EBP- $\alpha$ has been shown to induce growth arrest independent of DNA binding, thus underscoring the potential complexity of C/EBP function (Harris et al., 2001). Regardless of its precise mode of action, an increase in $\mathrm{C} / \mathrm{EBP}-\delta$ protein concentraton is likely to 
reflect an increase in its regulatory activity. For these reasons, I initially hypothesized that an increase in C/EBP- $\delta$ protein concentrations in $T$. bernacchii, brought on by heat stress, would occur concomitantly with an increase in nuclear localization of this transcription factor and that these phenomena would be correlated with cessation of the cell cycle. However, the overall complexity of cell cycle progression across treatments in T. bernacchii, the marked tissue specificity and temporal sensitivity together allude to a mechanism (or suite of mechanisms) remarkably different from that which was originally hypothesized. My results require an updated model of cellular stress response in Antarctic fishes--a model which may be broken down into two categories: sublethal and lethal.

The new model: sublethal and lethal heat stress responses in Antarctic fishes The upper thermal maximum for T. bernacchii is $6-7^{\circ} \mathrm{C}$ (Somero and DeVries, 1967). Therefore, "sublethal heat stress" is generally regarded to be between $2^{\circ} \mathrm{C}$ and $4{ }^{\circ} \mathrm{C}$ in those Antarctic fishes which inhabit the highest latitudes. At these lower temperatures, animals can be held for at least one month and perhaps indefinitely (e.g., Sleadd and Buckley, 2013). It was 
previously reported that hepatocytes isolated from T. bernacchii are able to remain viable for hours and perhaps days at temperatures as high as $10^{\circ} \mathrm{C}$ (Hofmann et al., 2000), indicating that the upper lethal limit for the intact organism does not always equate to the upper lethal limit for isolated cells. Nevertheless, there appears to be a certain temperature threshold above which apoptosis is favored in T. bernacchii. That threshold corresponds roughly to the upper lethal limit of the intact organism $\left(6-7^{\circ} \mathrm{C}\right.$; Chapter 5; Fig. 49).

For T. bernacchii, sublethal temperatures may cause an initial arrest in G1, as evidenced by an increase in the proportion of isolated hepatocytes in G1 and a concomitant decrease in the proportion of cells in S phase (Chapter 5; Fig. 49). This is supported by an initial decrease in protein concentrations of liver PCNA in vivo (Chapter 4; Fig. 40). This growth arrest is consistent with my initial hypotheses and prima facie this appears to be indicative of an adaptive response--cessation of cellular proliferation in the face of sublethal heat stress. At later time points, however, apoptosis is initiated by cells currently in the G1 phase of the cell cycle. This is demonstrated by a decrease in the proportion of G1 cells and a mirror-image increase in the proportion of apoptotic cells (Chapter 5; Fig. 49). At lethal temperatures, apoptosis occurs much sooner--as early as $4 \mathrm{~h}$--with no clear sign of an adaptive cell cycle 
arrest. The initiation of apoptosis in T. bernacchii is preceded by induction of C/EBP- $\delta$ at $6 \mathrm{~h}$ in at least one tissue type in vivo (Chapter 2; Figs. 4-5). The C/EBP- $\delta$ transcription factor has known roles in apoptosis ( $\mathrm{O}^{\prime}$ Rourke et al., 1999; Thangaraju et al., 2005), although protein levels in liver tissue were always below detectable limits in T. bernacchii (Chapter 2). Apoptosis in $T$. bernacchii hepatocytes may therefore occur through C/EBP- $\delta$-independent pathways in response to sublethal heat stress.

There are numerous additional apoptosis-related genes whose heatinduction in T. bernacchii makes them likely suspects for mediating programmed cell death in this species' hepatocytes. Buckley and Somero (2009) demonstrated that mRNA levels of Bcl2-like protein 13, caspase-3 precursor, death-associated protein kinase 3 and growth arrest and DNA damage associated protein 45 (GADD45) are all induced following sublethal heat stress at $4^{\circ} \mathrm{C}$. The last, GADD45, was the center of a recent study in our lab. Protein levels were found to increase significantly in response to sublethal, but not lethal, temperature stresses in isolated liver samples (Hassumani, personal communication), further supporting the idea of a temperature threshold in the T. bernacchii stress response. Protein concentrations of GADD45 became significantly elevated above control levels 
as early as $2 \mathrm{~h}$ following exposure to $2^{\circ} \mathrm{C}$. Besides taking part in apoptosis, GADD45 is known to associate with other mediators of cell cycle progression including PCNA.

In tissue types besides liver, for instance in white skeletal muscle, which showed an early heat induction of C/EBP- $\delta$ in the present study (Chapter 2: Figs. 4-5), C/EBP-ठ may indeed play a role in apoptosis in $T$. bernacchii and other Antarctic fishes. In all tissue types, C/EBP- $\beta$ may be important in apoptosis and/or cell cycle regulation, since it is heat inducible in T. bernacchii at the mRNA level (Buckley and Somero, 2009), and this transcription factor has somewhat overlapping roles with C/EBP- $\delta$ (LekstromHimes and Xanthopoulos, 1998; Ramji and Foka, 2002).

Contrary to my early hypotheses, C/EBP- $\delta$ does not seem to be involved in the initial G1 growth arrest, since heat induction of C/EBP- $\delta$ occurs hours after the observed growth arrest. Furthermore, protein concentrations of PCNA and C/EBP- $\delta$ appear to be positively correlated in untreated fish $\left(-1.0 \pm 0.5^{\circ} \mathrm{C}\right.$; Fig. 46), perhaps due to increased binding of C/EBP- $\delta$ in the promotor region of the PCNA gene. Although the T. bernacchii PCNA promotor has not been sequenced, there is a CCAAT binding sequence in the promotor region of human PCNA (Paunesku et al., 2001). Both C/EBP- $\delta$ 
and PCNA appear to be heat inducible in many tissue types, but no correlation in heat-stressed animals was observed (Fig. 47), indicating that these proteins' expressions are not temporally coincident during stress.

Although a direct role for $\mathrm{C} / \mathrm{EBP}-\delta$ in cell cycle arrest and apoptosis has not yet been demonstrated in T. bernacchii hepatocytes, it remains a possibility. Other potential players include those whose mRNA levels varied with sublethal heat stress, namely, GADD45, insulin-like growth factor, C/EBP- $\beta$, p21-RAC3 and ash1 (Buckley and Somero, 2009). For C/EBP-ס, besides intracellular control of cell cycle, there exist other potential implications for the upregulation of this transcription factor in different tissue types. For instance, during longer durations of heat stress, when apoptosis may increase significantly, C/EBP- $\delta$ may assist in coordinating a type of systemic immune response (e.g., increased efferocytosis) in order to help maintain homeostasis in the face of increased rates of cell death. This seems feasible given that C/EBP- $\delta$ and other C/EBP family members have been implicated in the vertebrate immune response (Lekstrom-Himes and Xanthopoulos, 1998; Ramji and Foka, 2002).

In summary, my results suggest that in response to heat at a sublethal level $\left(2-4^{\circ} \mathrm{C}\right)$, initial cell cycle arrest may occur, followed by apoptosis. These 
responses appear less dependent upon the upregulation of C/EBP- $\delta$ than what was originally hypothesized, and is likely to be mediated by complex interactions that may include PCNA, GADD45, C/EBP- $\beta$, insulin-like growth factor, p21-RAC3, ash1, Bcl2-like protein 13 and caspase-3 precursor. The detailed expression patterns and interactions of these gene products are yet to be elucidated. Lethal heat stress above $6^{\circ} \mathrm{C}$ favors apoptosis in T. bernacchii. Antarctic fishes may therefore be able to respond adaptively to short-term, modest increases in water temperature by temporarily exiting the cell cycle. More severe heat stress causes widespread apoptosis, a condition which may help set the upper thermal maxima in these ecologically sensitive animals. 


\section{Figures}

Figure 1. Length versus mass plot for Pagothenia borchgrevinki (filled squares) and Trematomus bernacchii (filled triangles) collected in McMurdo Sound during the 2010 field season. The slopes of both lines were significantly nonzero and different from one another $(p<0.05)$.

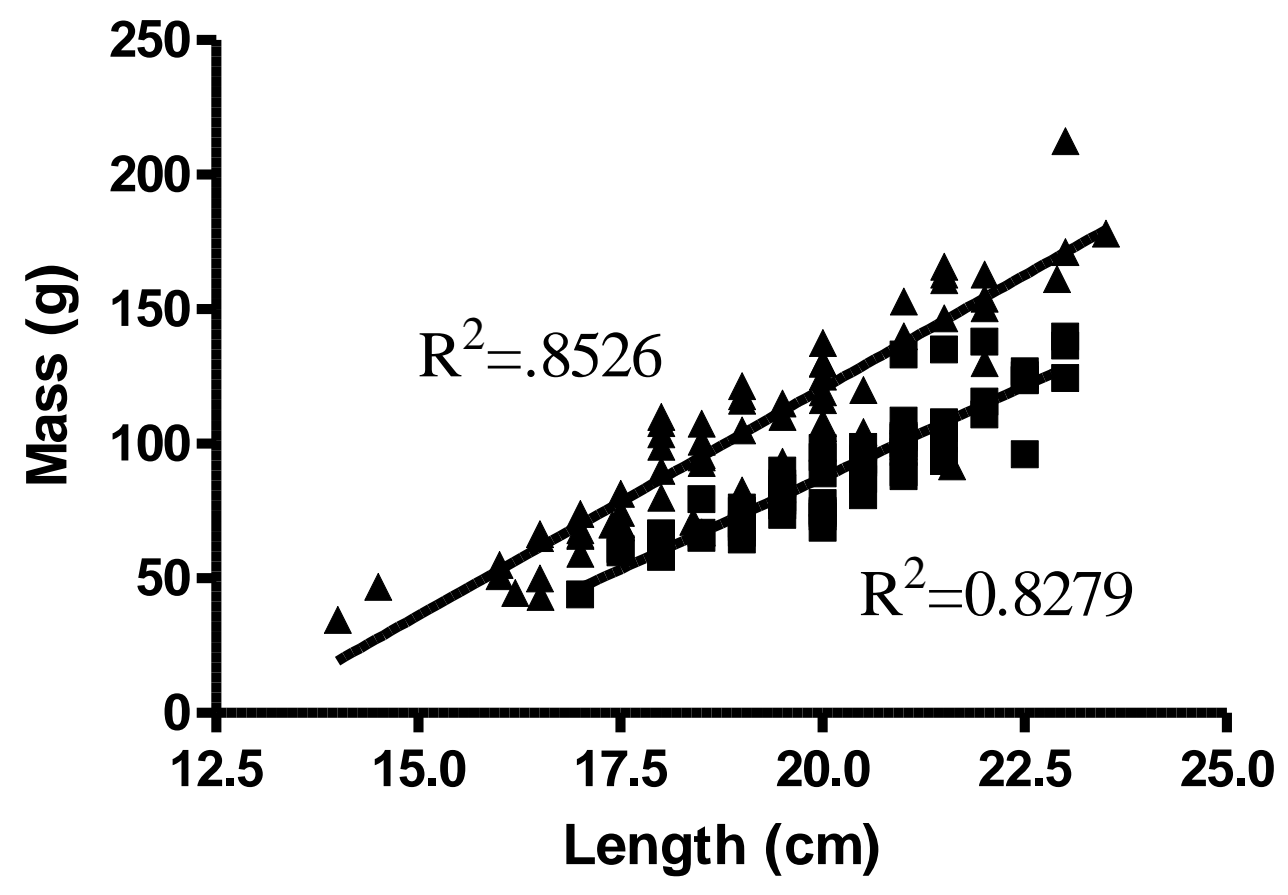


Figure 2. Multi-tissue analysis of C/EBP- $\delta$ protein levels in three field-caught ($1.86 \pm 0.5^{\circ} \mathrm{C}$ ), untreated Trematomus bernacchii. Blots are arranged from greatest (top) to least (bottom) protein concentration. No C/EBP- $\delta$ was detected in heart or liver tissue.

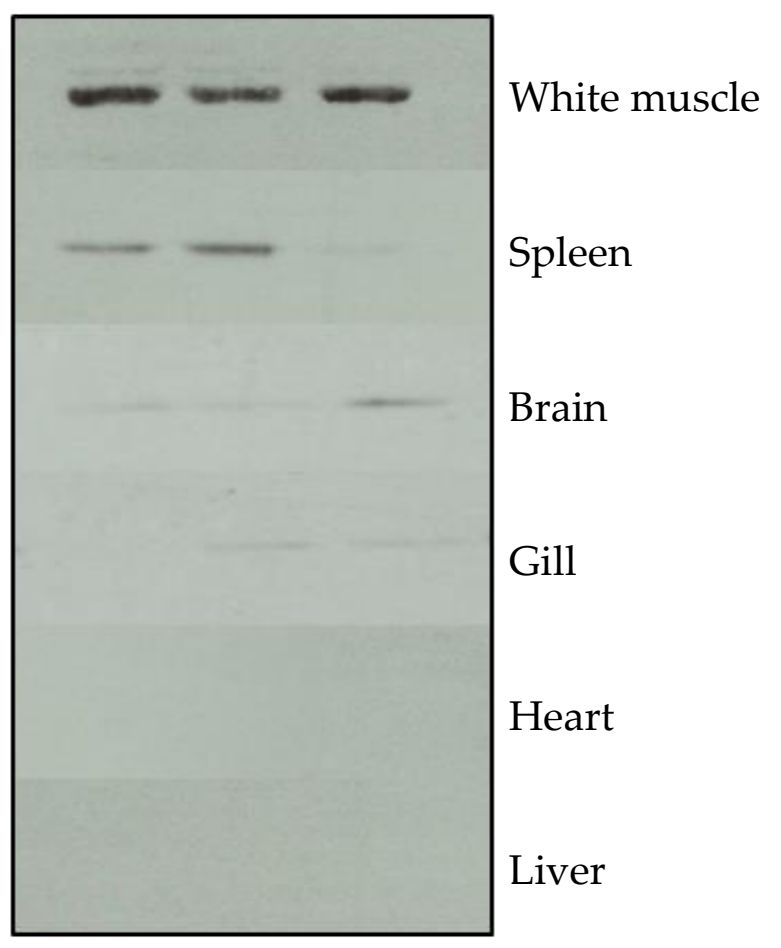


Figure 3. Protein levels of C/EBP- $\delta$ in field-acclimated $(n=10)$ vs. $4.0^{\circ} \mathrm{C}-$ acclimated $(n=5)$ Trematomus bernacchii white muscle tissue. Bars are mean + SEM. *Values were significantly different (student's $t$ test; $p<0.0001$ ).

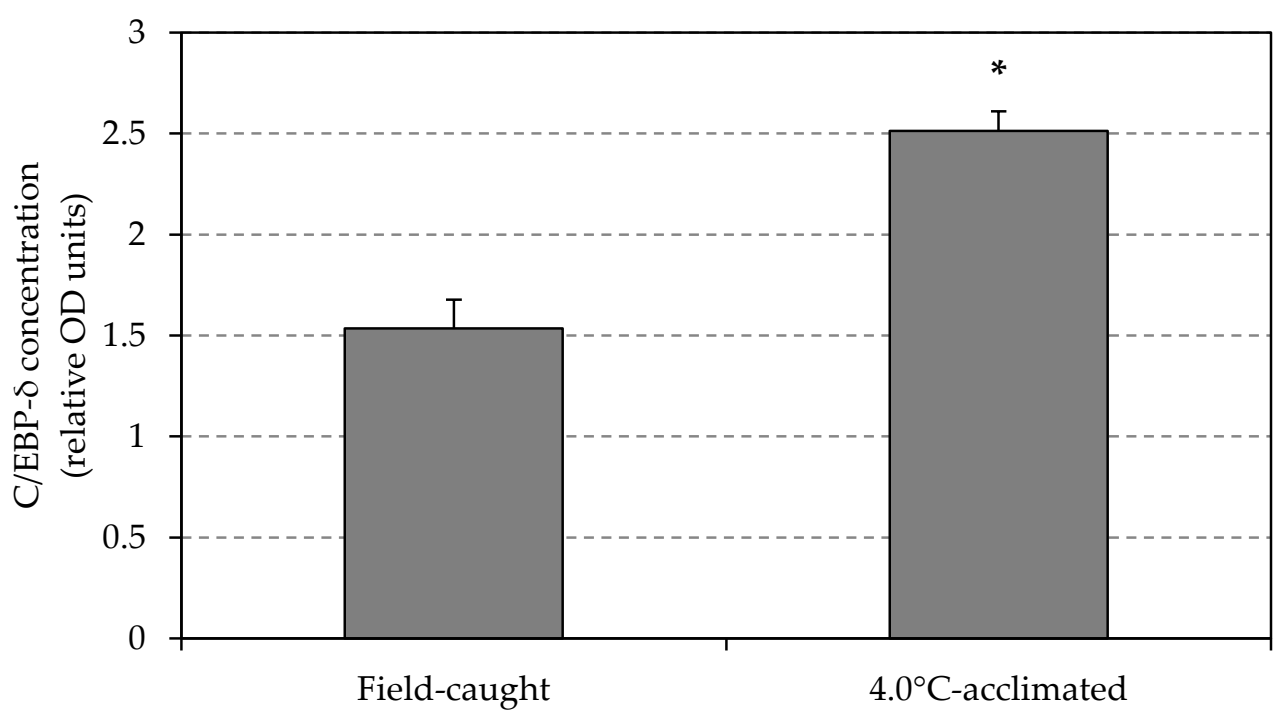


Figure 4. Protein levels of C/EBP- $\delta$ in Trematomus bernacchii white muscle tissue during $4.0^{\circ} \mathrm{C}$ heat shock and subsequent recovery at $-1.0 \pm 0.5^{\circ} \mathrm{C}$. Three individuals were sampled at each time point, with the exception of the $24 \mathrm{~h}$ recovery time point $(n=2)$. Bars are mean + SEM. *Significantly different from $0 \mathrm{~h}$ control group (ANOVA; $p<0.05$ ).

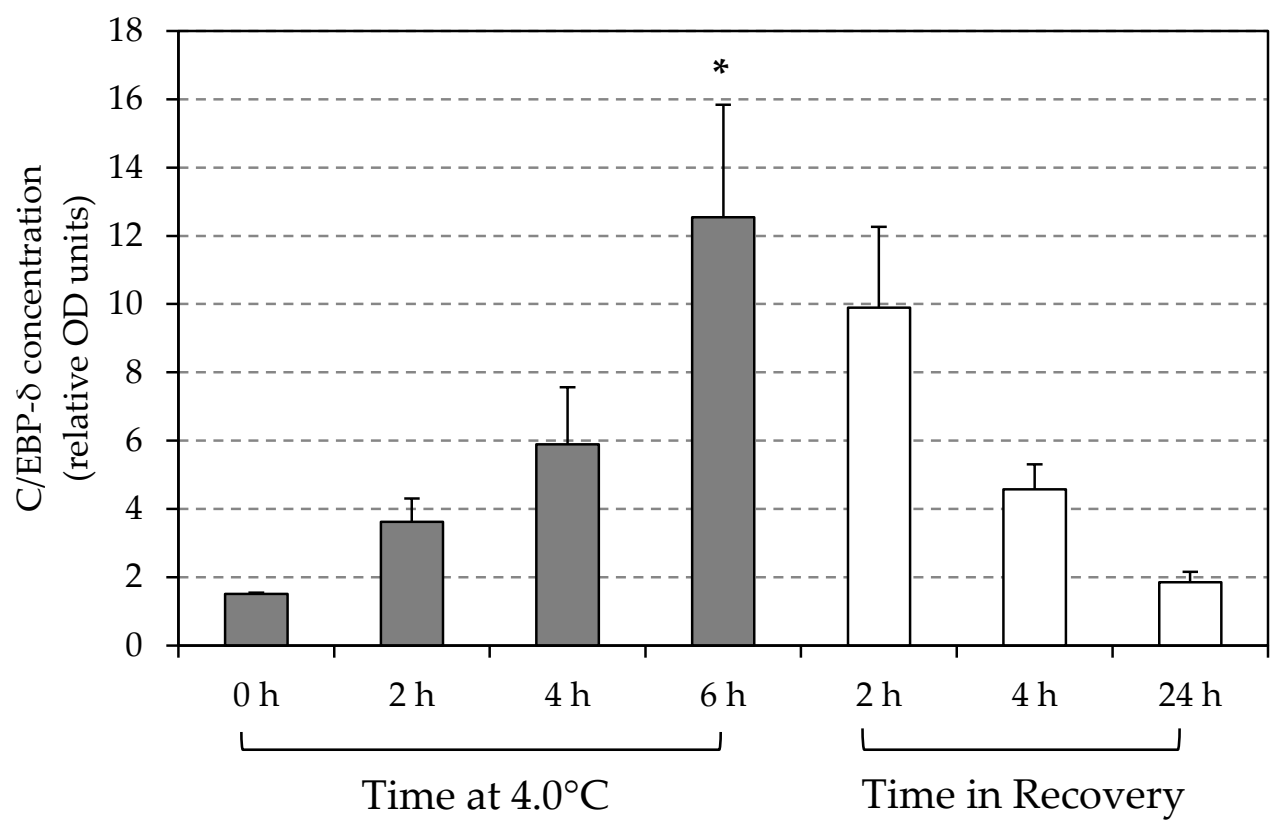


Figure 5. C/EBP- $\delta$ protein levels in control and heat-stressed Trematomus bernacchii spleen and white muscle as determined by western blot.

Temperature had a significant effect (two-way ANOVA; $F=6.127 ; p<0.05$ ), as did duration of treatment $(F=17.16 ; p<0.0001)$ for white muscle. The interaction between these variables was highly significant $(F=9.173 ; p=$ 0.0001). Bonferroni posttests revealed significant differences between temperature treatments at the 6-h time point (a vs. b $p<0.001$; a vs. c $p<0.01 ; \mathrm{b}$ vs. $c p<0.01)$. Bars are mean + SEM.
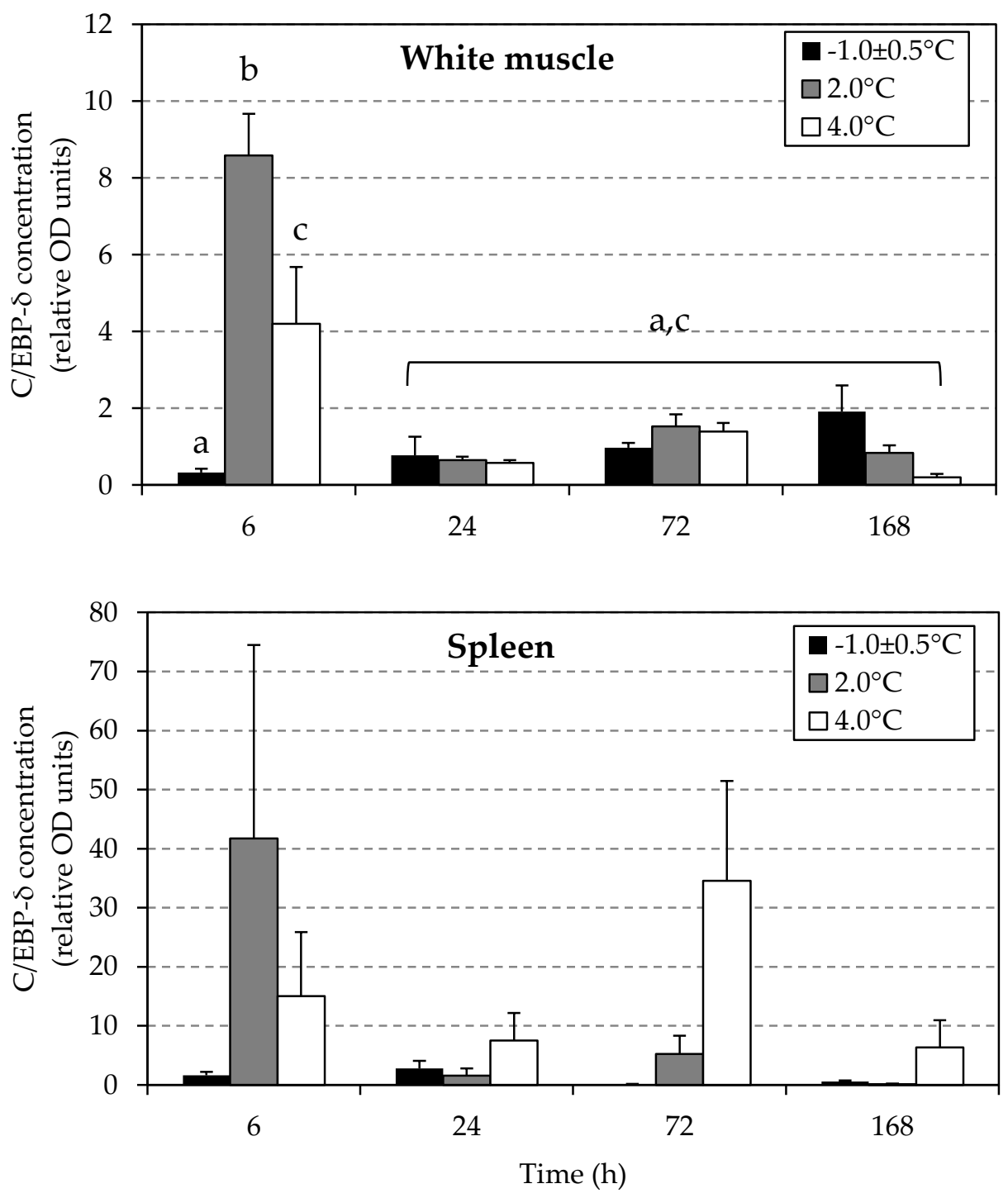
Figure 6. Splenic C/EBP- $\delta$ protein concentration versus body mass for Trematomus bernacchii held under control and heat-stress conditions for $72 \mathrm{~h}$ (triangles) or $168 \mathrm{~h}$ (squares). Top panel: animals held at $-1.0 \pm 0.5^{\circ} \mathrm{C}(n=6)$. Middle panel: animals held at $2.0^{\circ} \mathrm{C}(n=6)$. Bottom panel: animals held at $4.0^{\circ} \mathrm{C}(n=6)$.
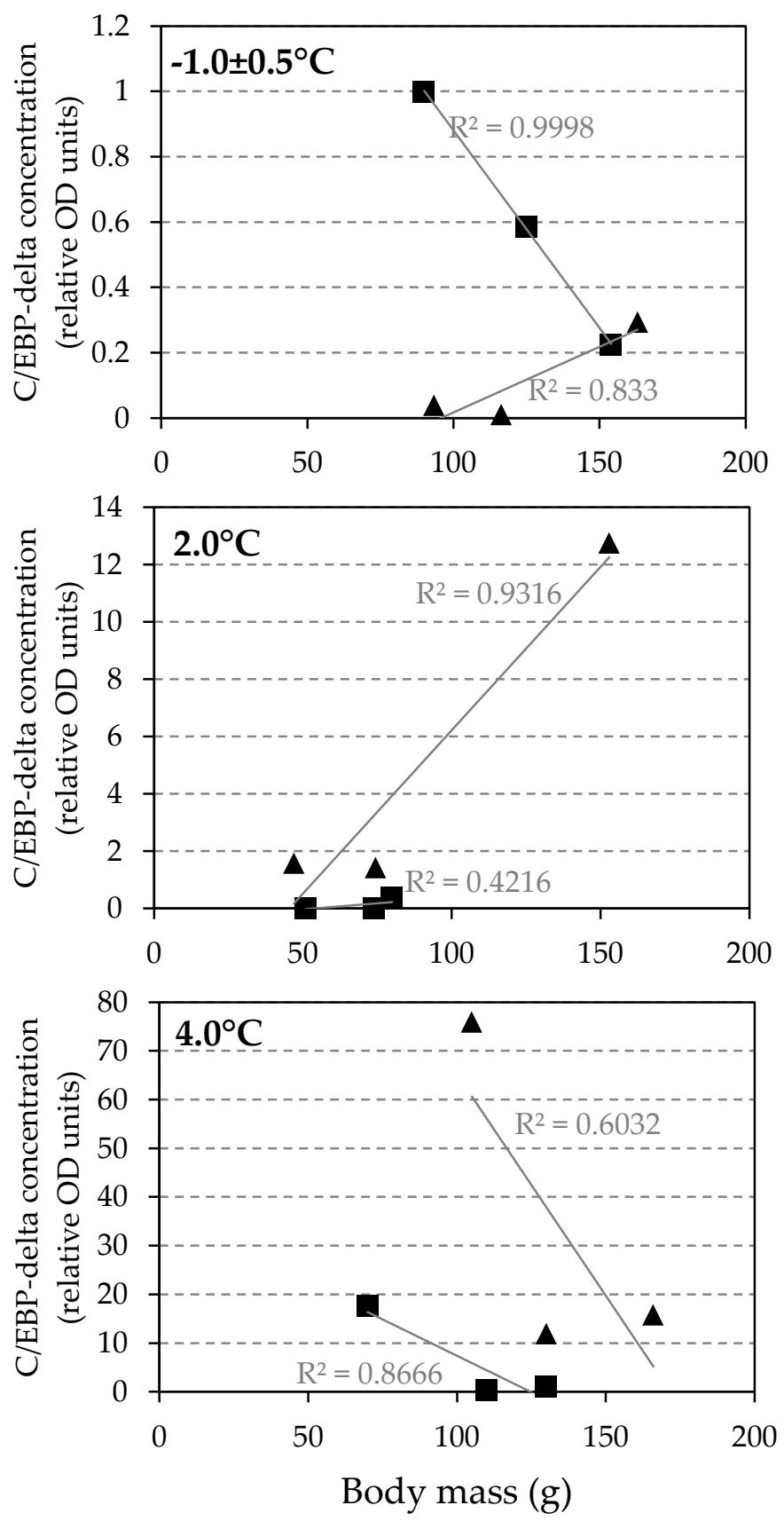
Figure 7. C/EBP- $\delta$ protein levels in control and heat-stressed Pagothenia borchgrevinki spleen as determined by western blot. Each panel reveals one experiment run back to back. Top panel: time had a significant effect on C/EBP- $\delta$ concentration (two-way ANOVA; $F=4.845 ; p<0.05$ ). Bottom panel: two-way ANOVA revealed no significant differences between treatments. Bars are mean + SEM.
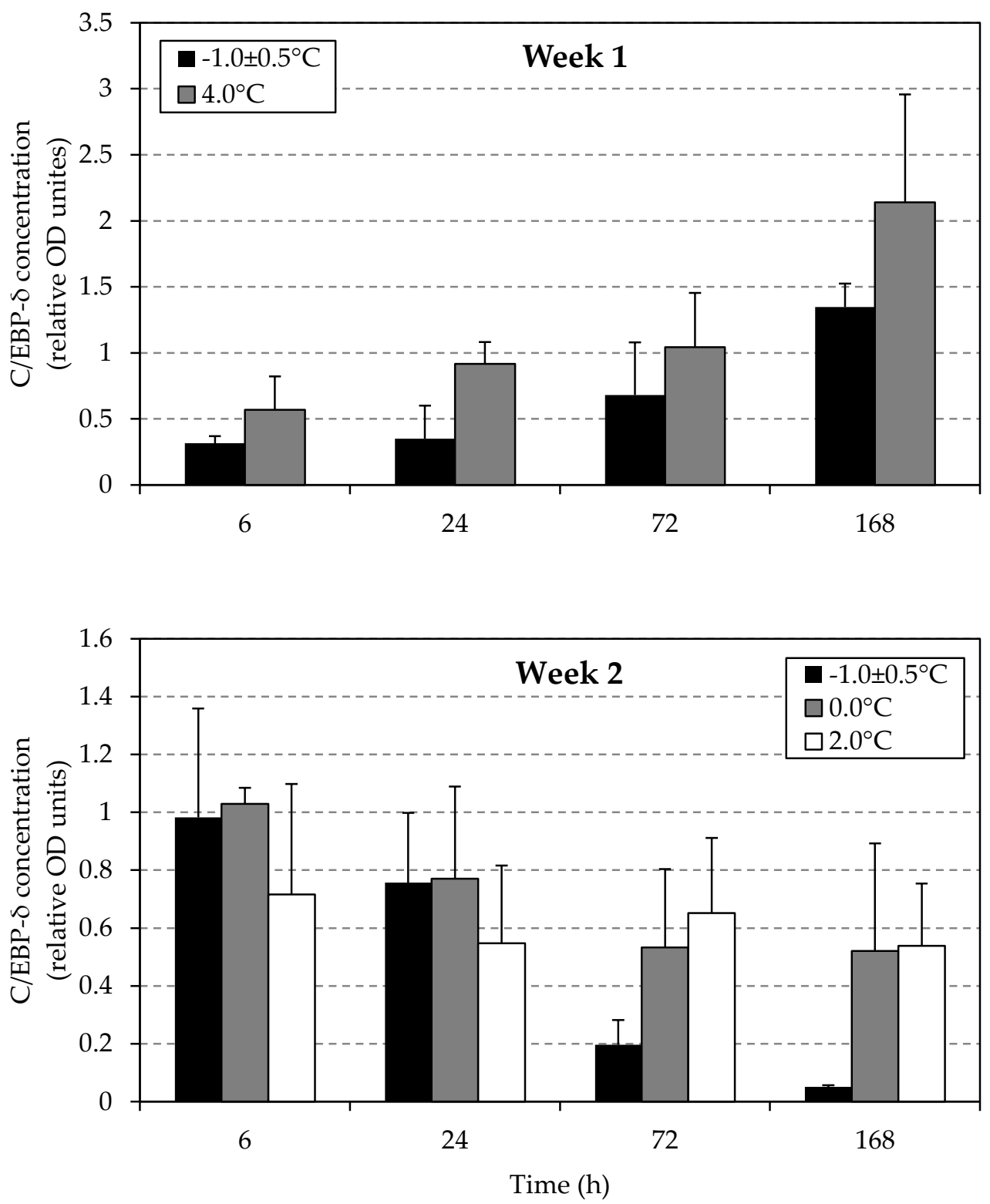
Figure 8. Experimental heat exposure. Heat-stressed zebrafish were ramped up from $28.5^{\circ} \mathrm{C}$ to $35.5^{\circ} \mathrm{C}$ at a rate of $+2.0^{\circ} \mathrm{C}$ per hour, held at $35.5^{\circ} \mathrm{C}$ for $2 \mathrm{~h}$, then sampled (filled circle). Control fish were held at $28.5^{\circ} \mathrm{C}$ for the duration of the experiment and sacrificed at $325 \mathrm{~min}$ (open circle) along with the heatstressed fish. $N=4$ for both sample points.

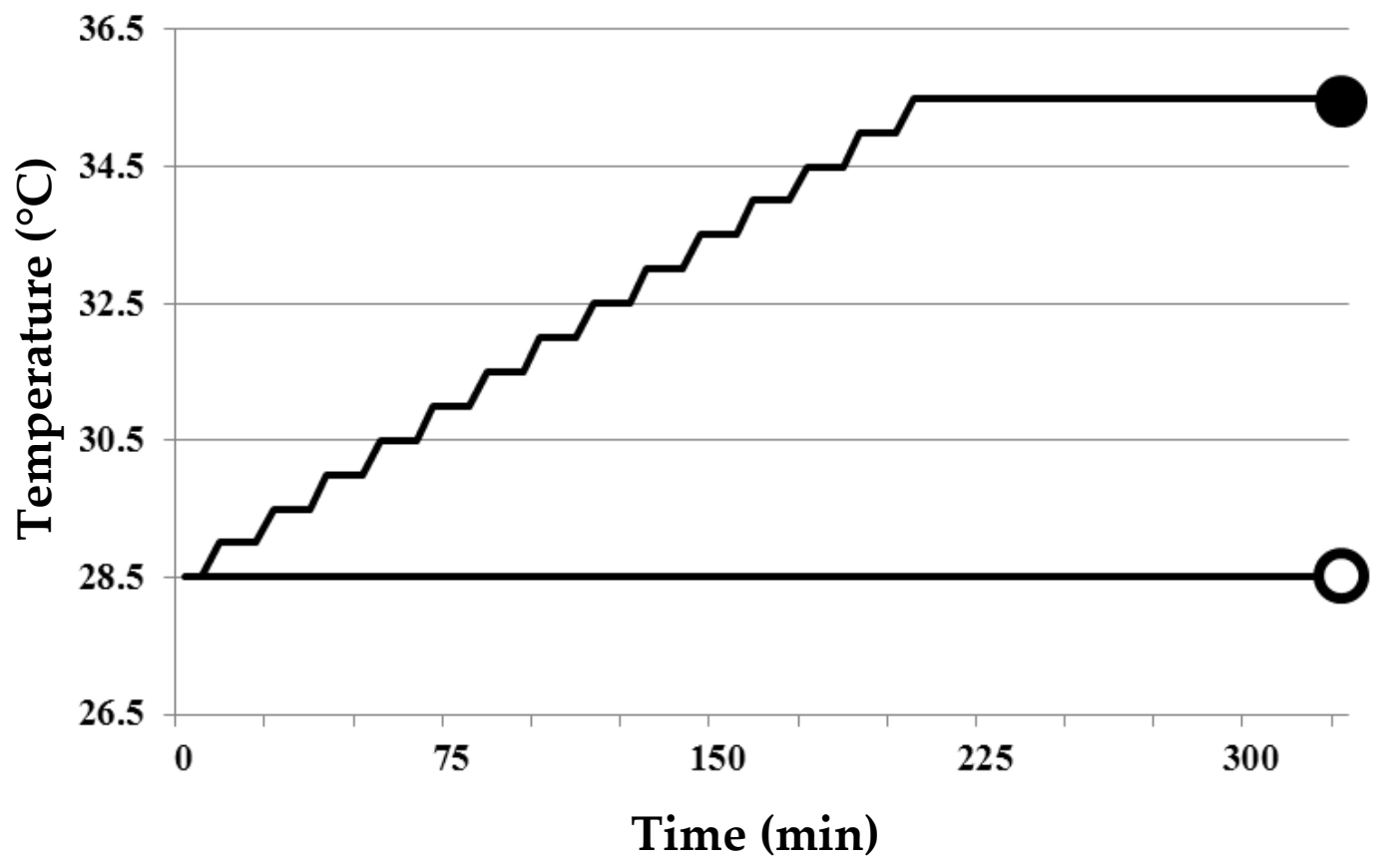


Figure 9. Negative control slide for $\mathrm{C} / \mathrm{EBP}-\delta \mathrm{IHC}$ reveals minimal to no DAB staining. Zebrafish retinal sections were incubated in $1 \times$ PBS and $2.5 \%$ normal horse serum overnight, instead of the usual primary antibody solution. Top panel: control $\left(28.5^{\circ} \mathrm{C}\right)$. Bottom panel: heat stress $\left(35.5^{\circ} \mathrm{C}\right)$.

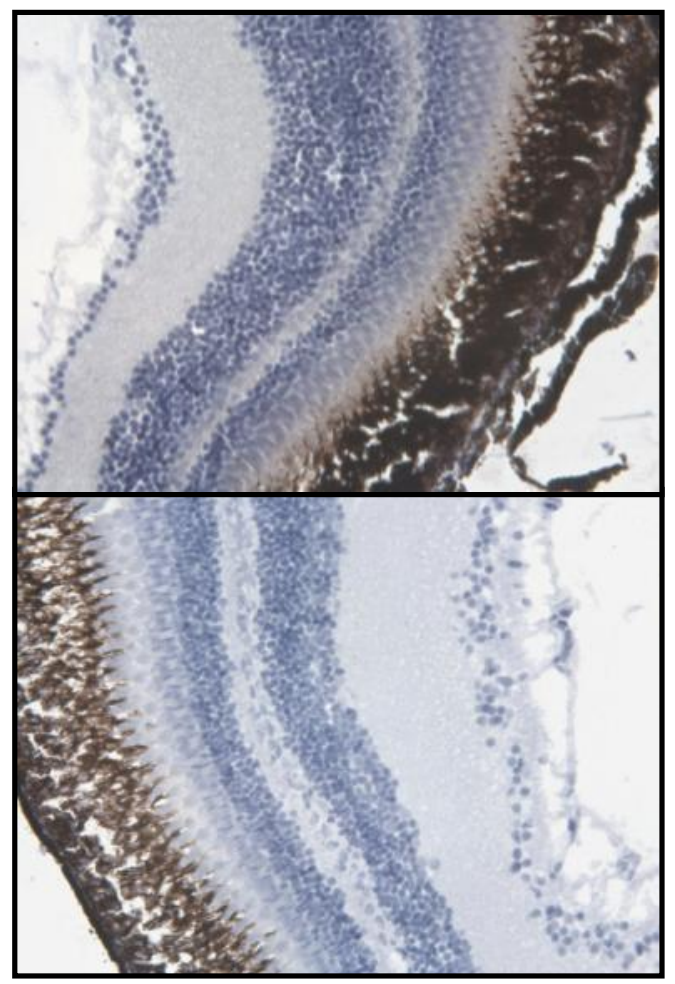


Figure 10. Positive control slide for TUNEL IHC. A human promyelocytic leukemia cell line (HL60) was incubated with $0.5 \mu \mathrm{g} / \mathrm{ml}$ actinomycin D for $19 \mathrm{~h}$ to induce apoptosis (provided by Phoenix Flow Systems).

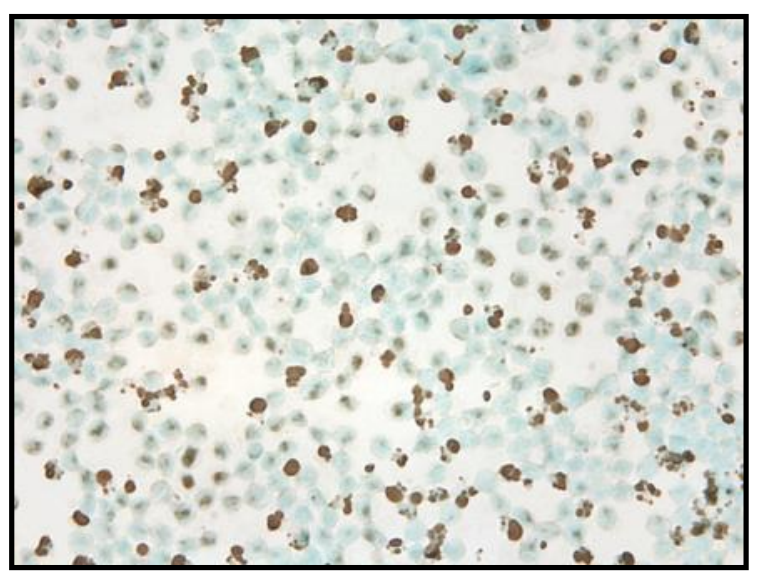


Figure 11. Representative micrographs depicting H\&E, C/EBP- $\delta$ and TUNEL staining of heat-stressed $\left(35.5^{\circ} \mathrm{C}\right)$ and control $\left(28.5^{\circ} \mathrm{C}\right)$ zebrafish retinae. Increased DAB staining (brown color) indicates nuclear accumulation of C/EBP- $\delta$ protein and DNA nicks in ganglion cells (arrowheads), photoreceptors (arrows), and cells of the inner nuclear layer (INL; asterisks). The greatest change in TUNEL positivity was observed in ganglion cells and in the amacrine cells of the INL. B. Quantification of TUNEL-positive nuclei in the ganglion cell layer. Treatments are statistically different $(p<0.05)$ following the exclusion of a statistical outlier $(\dagger)$.

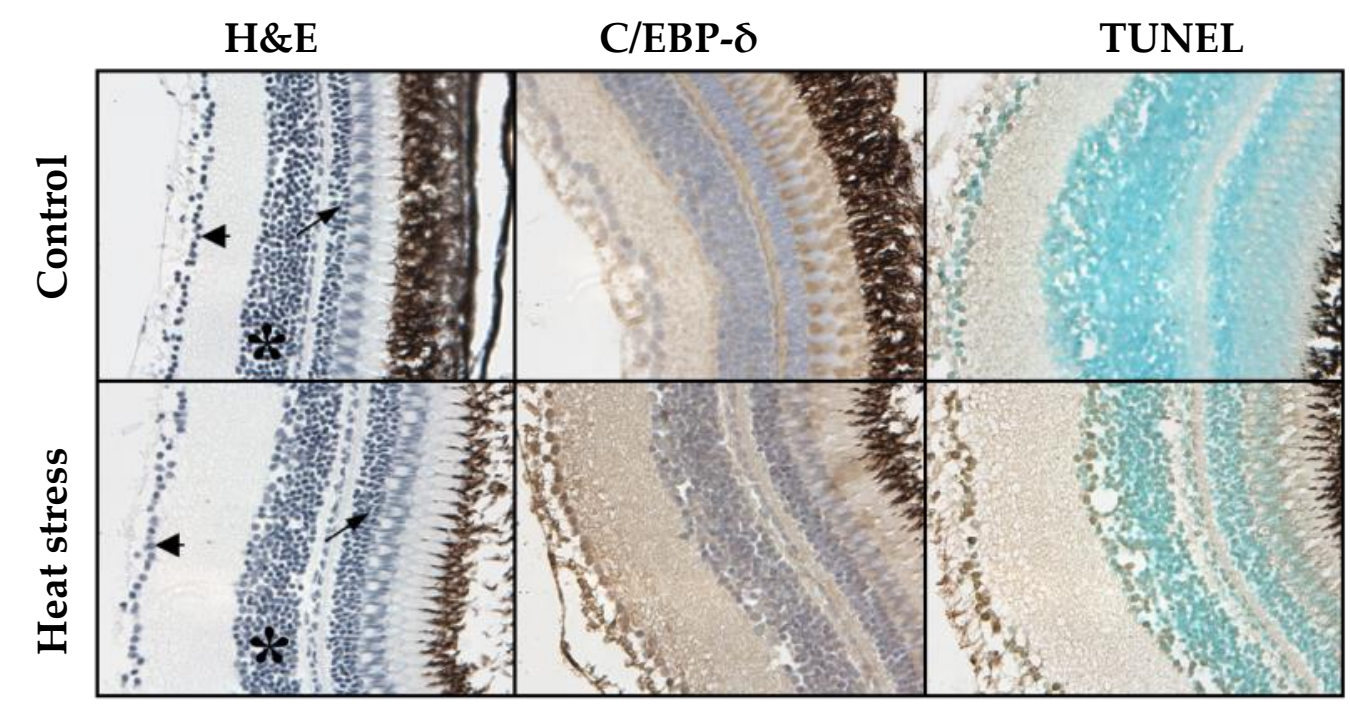

B.
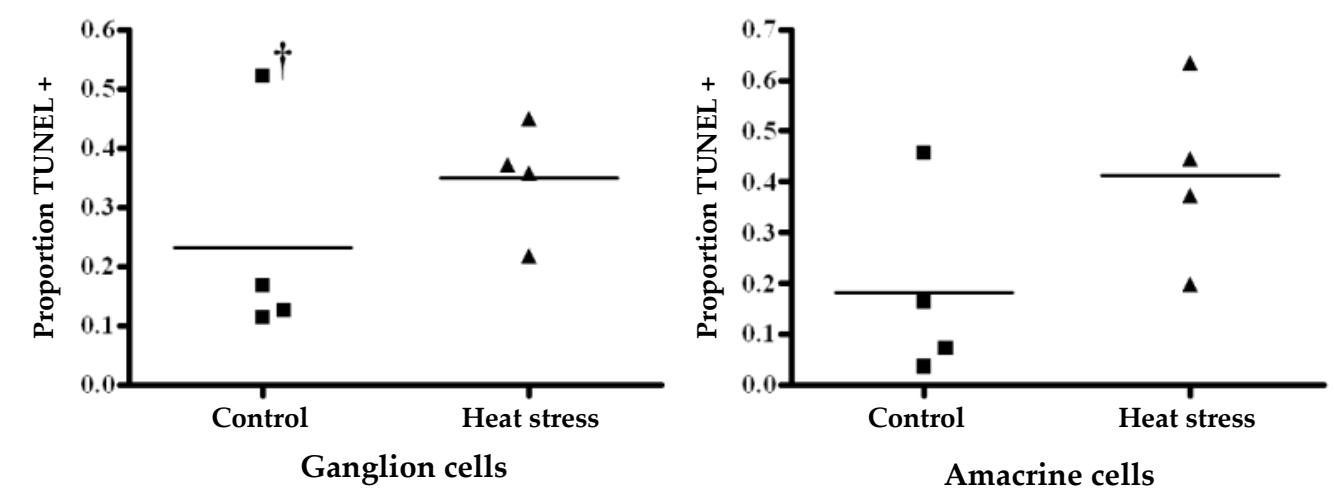
Figure 12. Color deconvolution of $C / E B P-\delta D A B$ stain from haematoxylin counterstain emphasizes the nuclear accumulation of $\mathrm{C} / \mathrm{EBP}-\delta$ protein in ganglion cells (arrowheads), photoreceptors (arrows), and cells of the inner nuclear layer (asterisks). In control $\left(28.5^{\circ} \mathrm{C}\right)$ animals, the most intense staining was observed in the outer plexiform layer and in the cytoplasm of the photoreceptors, whereas the photoreceptor nuclei exhibited the least intense staining. In contrast, the retinae from heat-stressed $\left(35.5^{\circ} \mathrm{C}\right)$ zebrafish showed moderate staining in nuclei of all cell types, the most intense being those of the retinal ganglion cells. These patterns were observed in all cases.

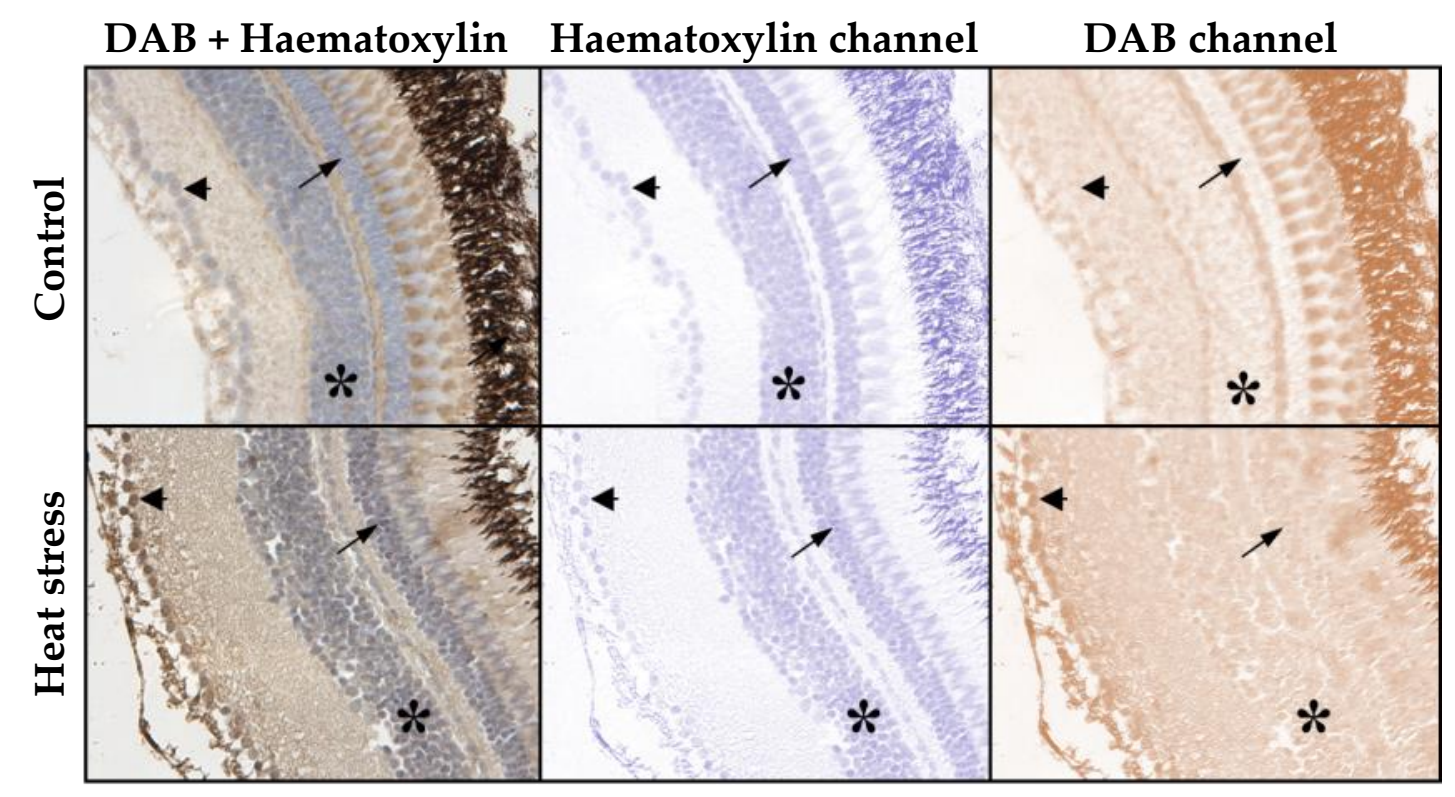


Figure 13. Color deconvolution of C/EBP- $\delta$ DAB stain from haematoxylin counterstain emphasizes the heat-induced nuclear accumulation of this transcription factor in cell layers of the zebrafish retina.

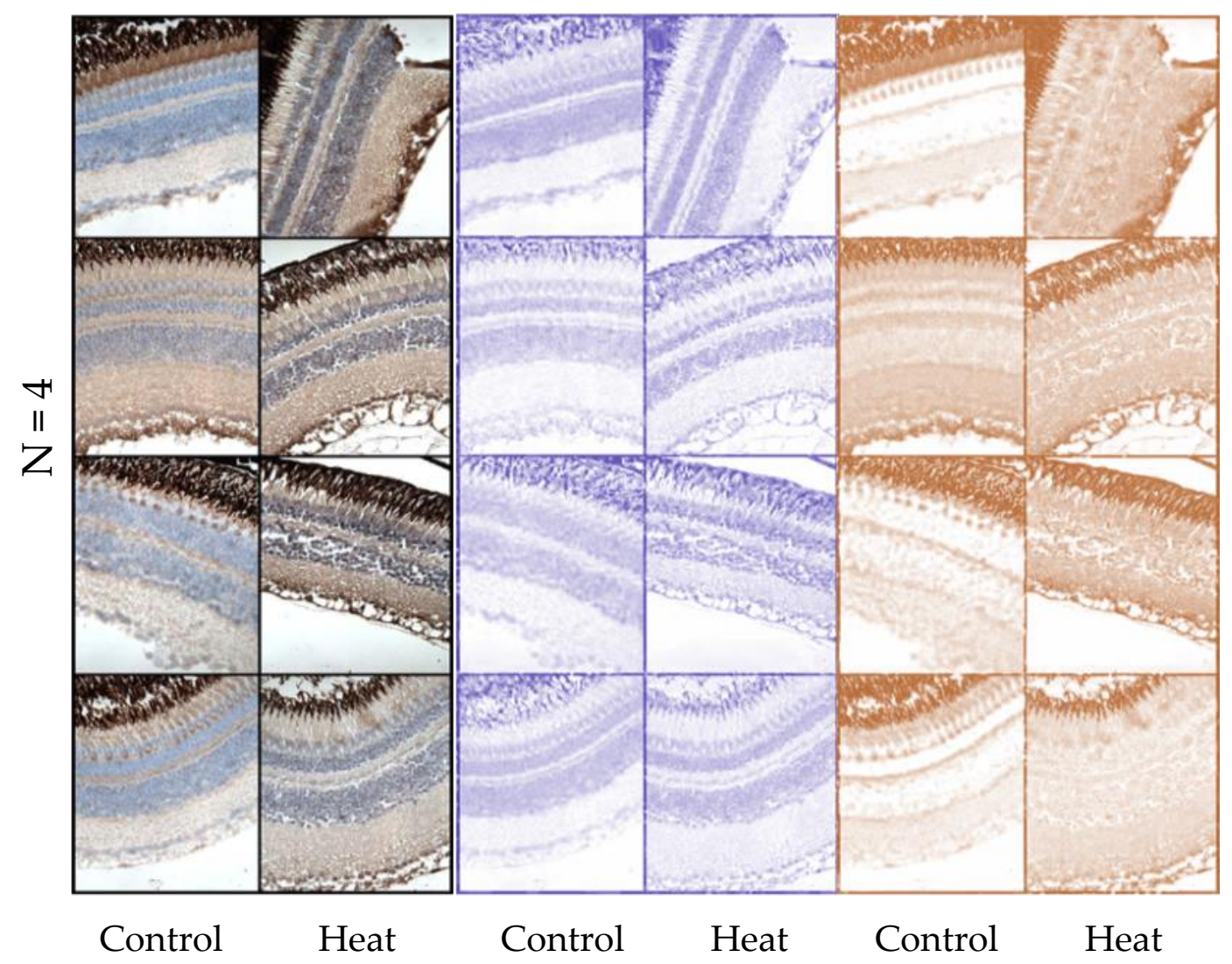


Figure 14. Quantification of C/EBP- $\delta$ DAB staining of separate retinal layers in heat-stressed $D$. rerio. Data are presented as mean difference + SEM for pixel intensities of $35.5^{\circ} \mathrm{C}$ and $28.5^{\circ} \mathrm{C}$ treatments. Retinal ganglion cell data were significantly different than 0 (Student's $t$ test). Photoreceptor layer (PL), outer nuclear layer (ONL), outer plexiform layer (OPL), inner nuclear layer (INL), inner plexiform layer (IPL), and ganglion cell nuclei (GCN).

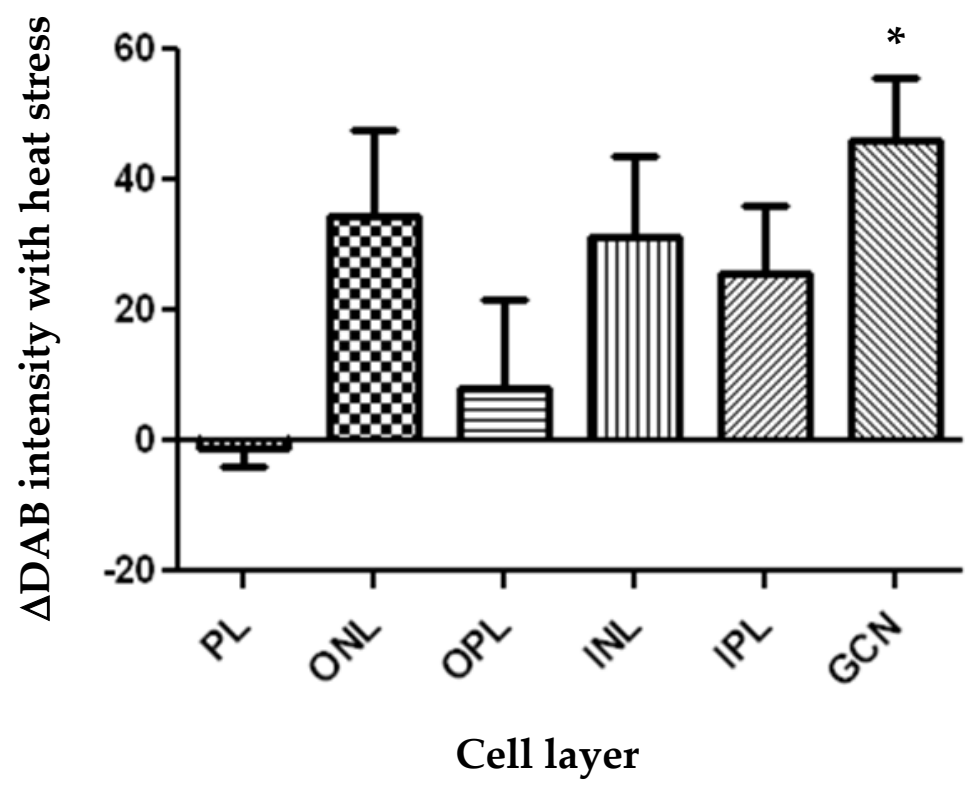


Figure 15. Representative micrographs depicting H\&E, C/EBP- $\delta$ and TUNEL staining of heat-stressed $\left(35.5^{\circ} \mathrm{C}\right)$ and control $\left(28.5^{\circ} \mathrm{C}\right)$ zebrafish white muscle. Histogram: Quantification of C/EBP- $\delta$ DAB staining in D. rerio white muscle. Data are presented as a ratio of mean pixel intensities between $35.5^{\circ} \mathrm{C}$ and $28.5^{\circ} \mathrm{C}$ treatments. ${ }^{*}$ data were significantly different than 1.0 (Student's $t$ test; $p$ $<0.05)$.
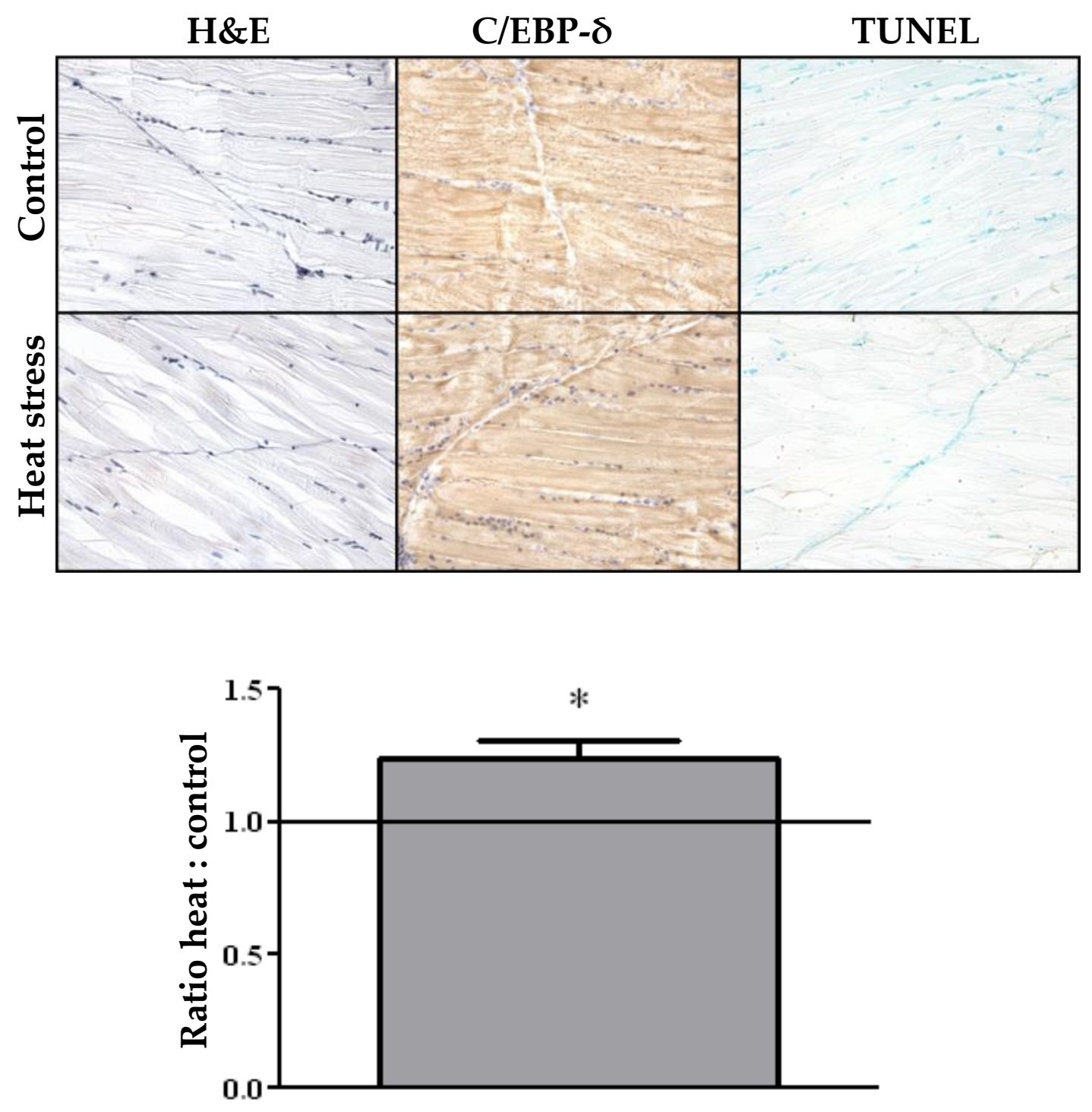
Figure 16. Representative micrographs depicting H\&E, C/EBP- $\delta$ and TUNEL staining of white matter from heat-stressed $\left(35.5^{\circ} \mathrm{C}\right)$ and control $\left(28.5^{\circ} \mathrm{C}\right)$ zebrafish optic tectum. $\mathrm{C} / \mathrm{EBP}-\delta \mathrm{DAB}$ staining was more intense in nuclei from heat-stressed individuals. Perinuclear halos (arrow) are characteristic of oligodendria, although other cell types may develop them under certain conditions. The high number of TUNEL-positive cells is likely to be artifactual. B. Quantification of TUNEL-positive nuclei in white matter from heat-stressed $\left(35.5^{\circ} \mathrm{C}\right)$ and control $\left(28.5^{\circ} \mathrm{C}\right)$ zebrafish optic tectum. There was no significant difference between treatments.

A.

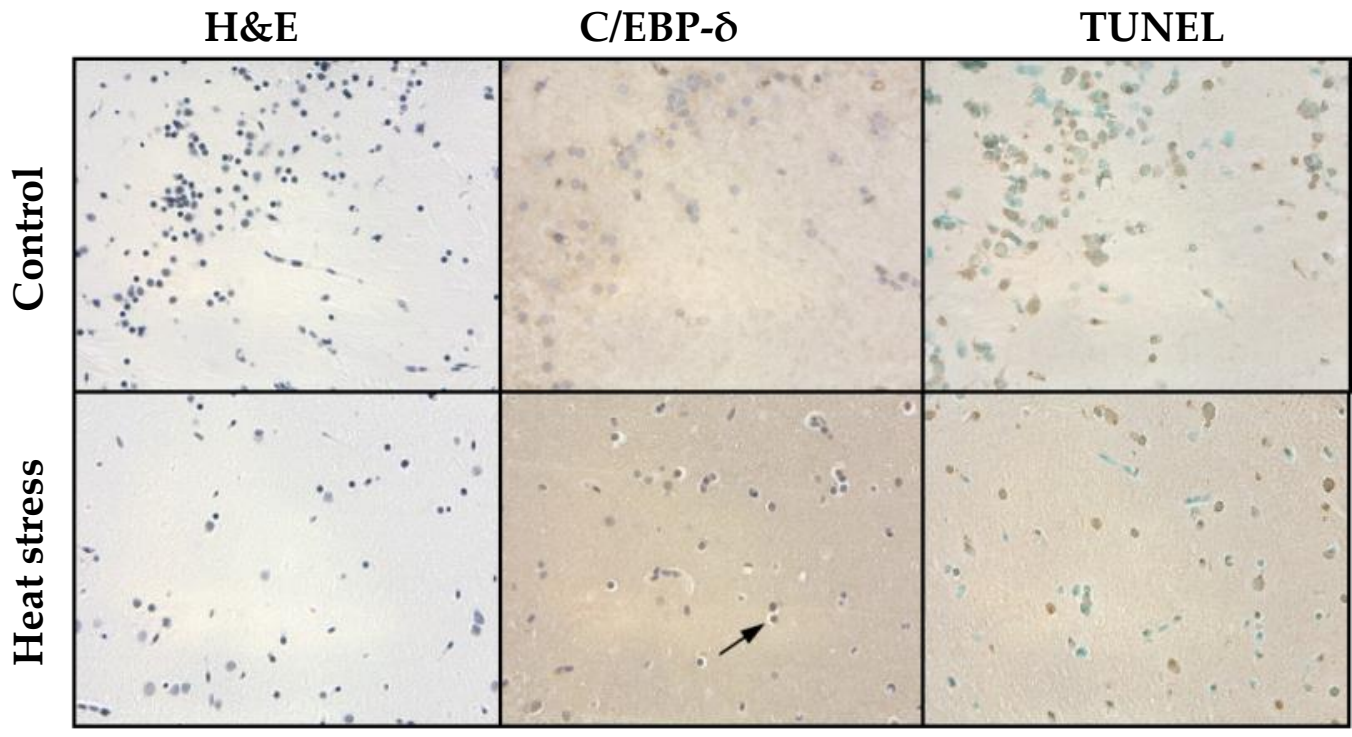

B.

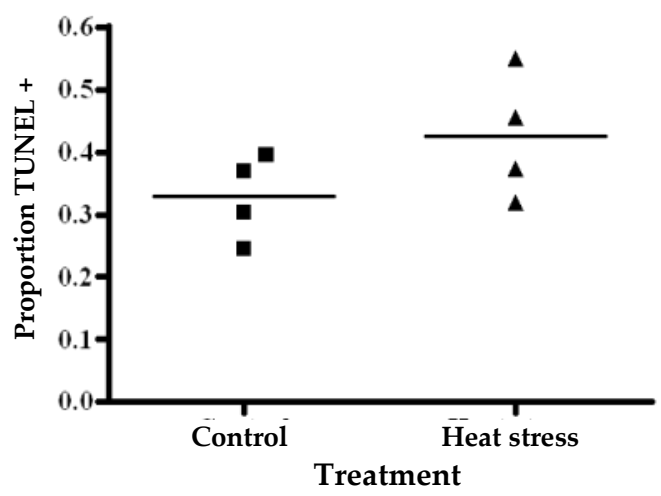


Figure 17. Representative color deconvolution of C/EBP- $\delta$ DAB stain from haematoxylin counterstain for zebrafish optic tectum white matter. Cells from control $\left(28.5^{\circ} \mathrm{C}\right)$ animals showed a relative absence of C/EBP- $\delta$ from their nuclei when compared to those from heat-stressed $\left(35.5^{\circ} \mathrm{C}\right)$ individuals. Cells from the control fish also exhibited more perinuclear staining, in contrast with nuclei from heat-stressed animals which in addition to having greater amounts of $C / E B P-\delta$ also showed a higher frequency of perinuclear halos. This appears to result from significant nuclear shrinkage. Arrows are included for easy reference.

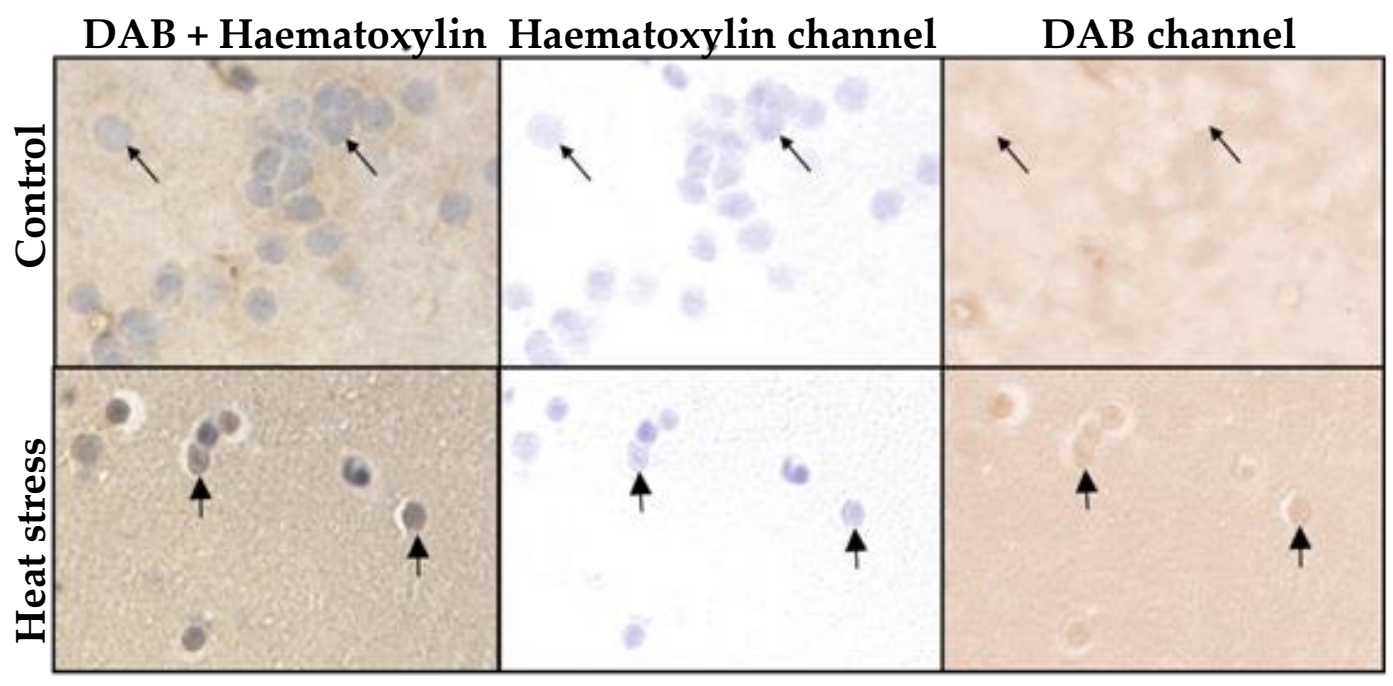


Figure 18. Color deconvolution of $\mathrm{C} / \mathrm{EBP}-\delta \mathrm{DAB}$ stain from haematoxylin counterstain for control $\left(28.5^{\circ} \mathrm{C}\right)$ and heat stressed $\left(35.5^{\circ} \mathrm{C}\right)$ zebrafish optic tecta. Increased DAB staining in the heat-stressed animals suggests higher protein concentrations of $\mathrm{C} / \mathrm{EBP}-\delta$.

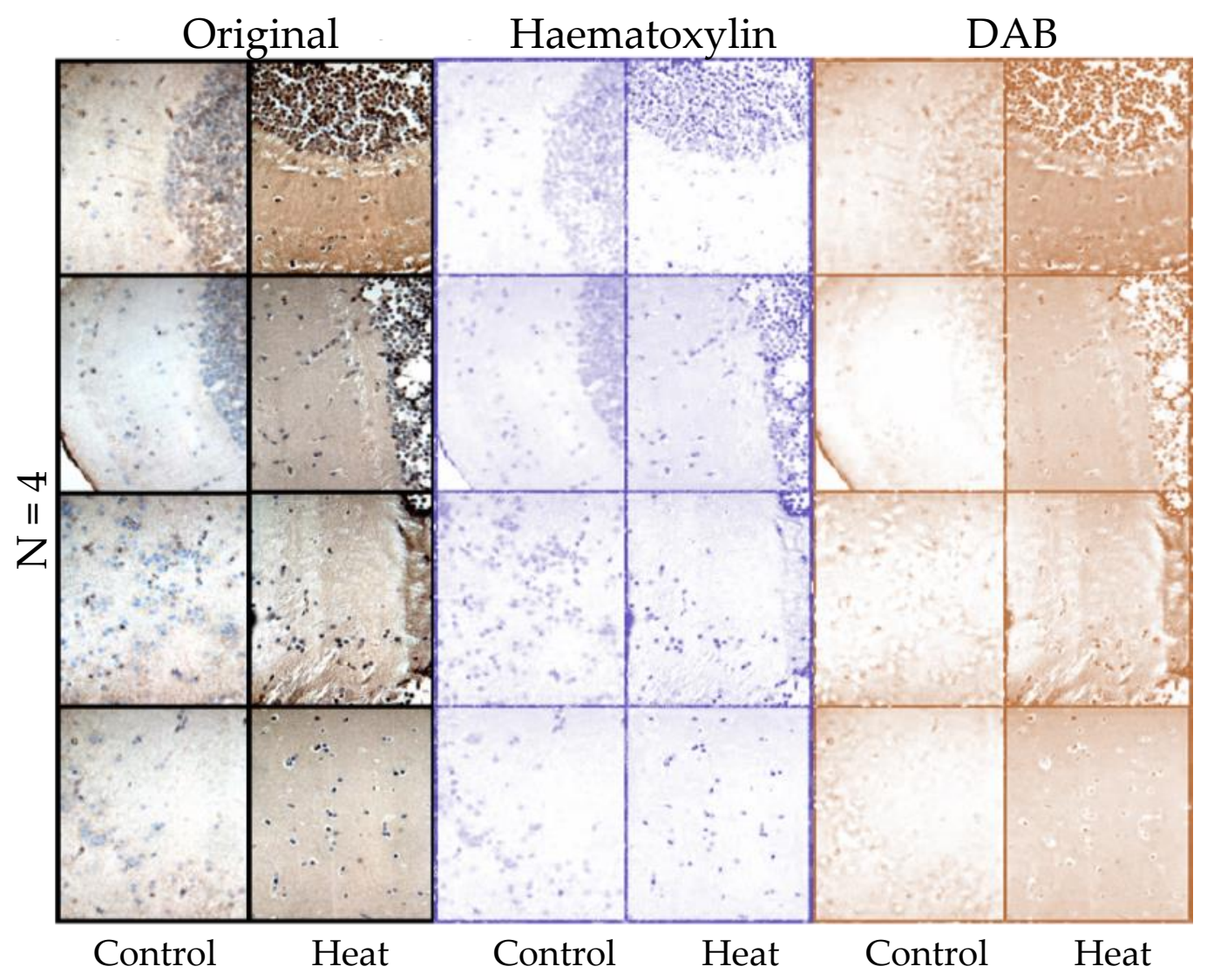


Figure 19. Representative micrographs depicting H\&E, C/EBP- $\delta$ and TUNEL staining of heat-stressed $\left(35.5^{\circ} \mathrm{C}\right)$ and control $\left(28.5^{\circ} \mathrm{C}\right)$ zebrafish livers. No differences in DAB or TUNEL staining were observed between treatments. B. A morphologically distinct and TUNEL-positive hepatocyte.

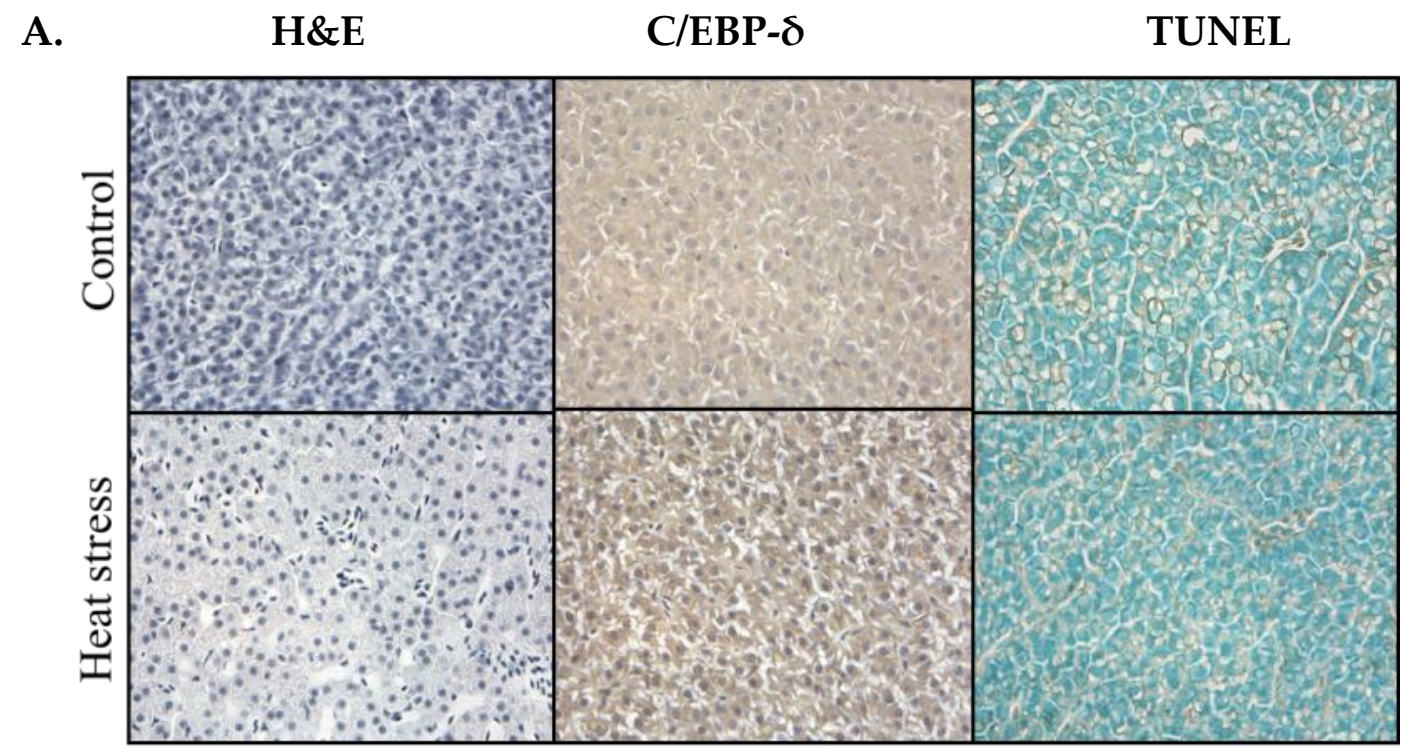

B.

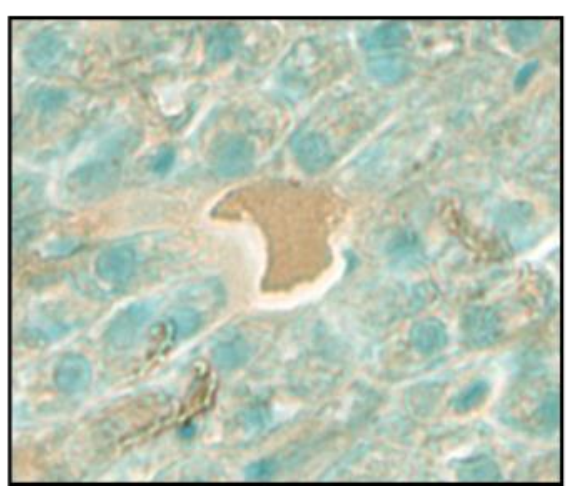


Figure 20. Color deconvolution of C/EBP- $\delta$ DAB stain from haematoxylin counterstain for control $\left(28.5^{\circ} \mathrm{C}\right)$ and heat stressed $\left(35.5^{\circ} \mathrm{C}\right)$ zebrafish livers. No differences were observed between treatments.

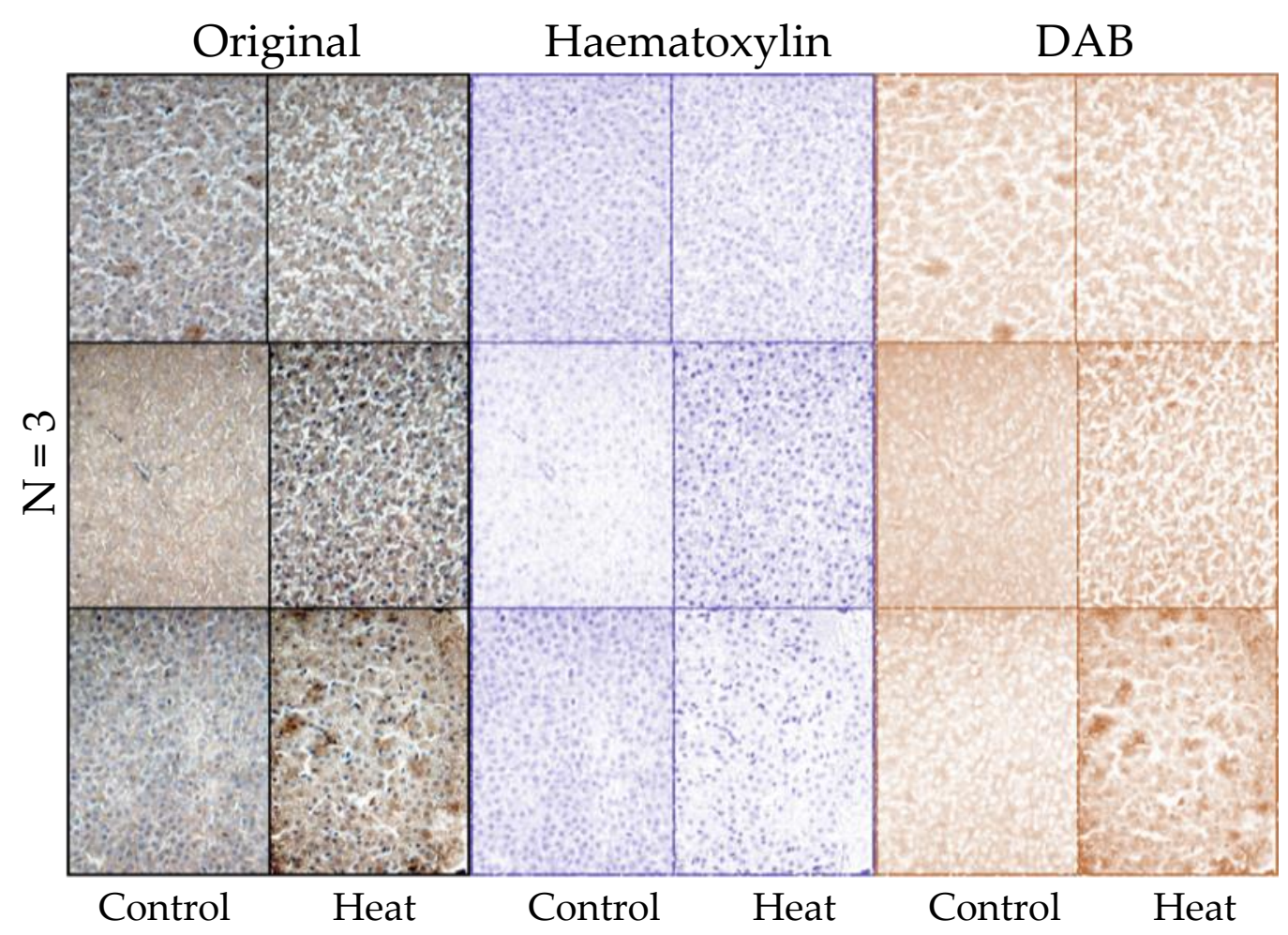


Figure 21. Nuclear C/EBP- $\delta$ concentrations in Trematomus bernacchii tissues following $6 \mathrm{~h}$ of heat stress. Data are presented as mean pixel intensity + SEM. *Means are statistically different (Student's $t$ test; $p<0.01$ ). † Means are almost significantly different (Student's $t$ test; $p=0.0613$ ). Each tissue type was run on a separate slide. Levels are not relative to an internal standard and inter-tissue comparisons should not be made.

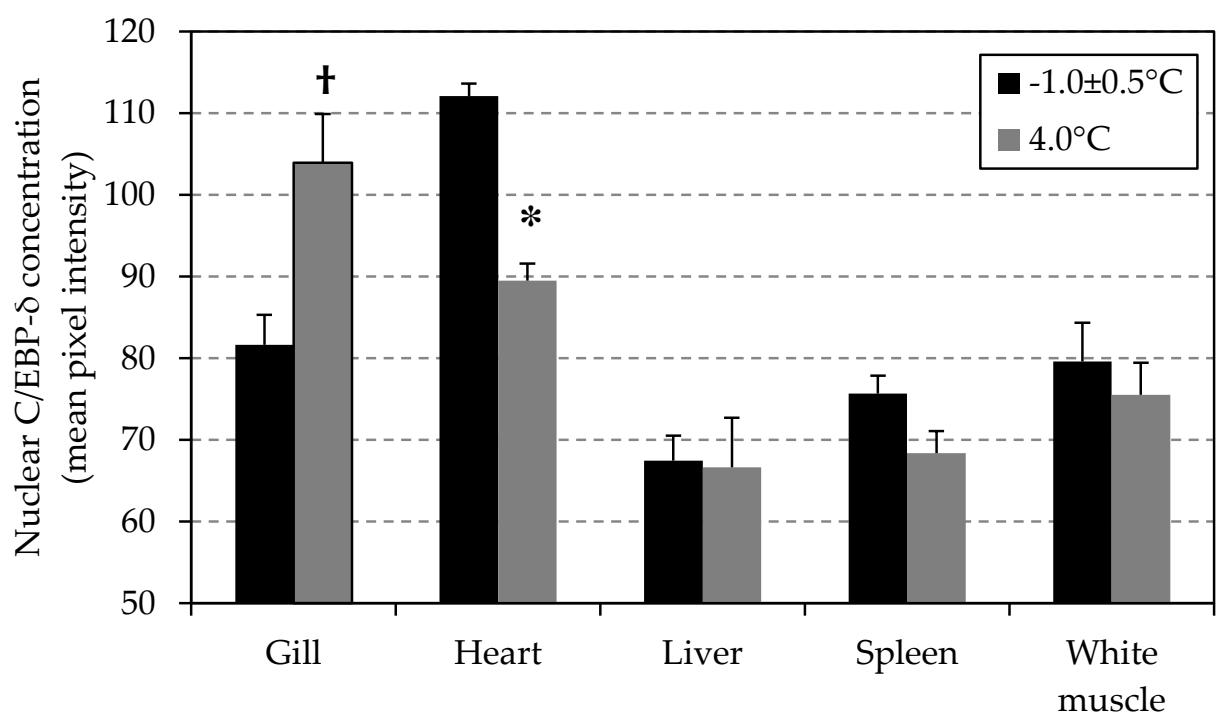


Figure 22. Nuclear C/EBP- $\delta$ concentrations in Pagothenia borchgrevinki tissues following $6 \mathrm{~h}$ of heat stress. Data are presented as mean pixel intensity + SEM. ${ }^{*}$ Means are statistically different (Student's $t$ test; $p<0.05$ ). Each tissue type was run on a separate slide. Levels are not relative to an internal standard and inter-tissue comparisons should not be made.
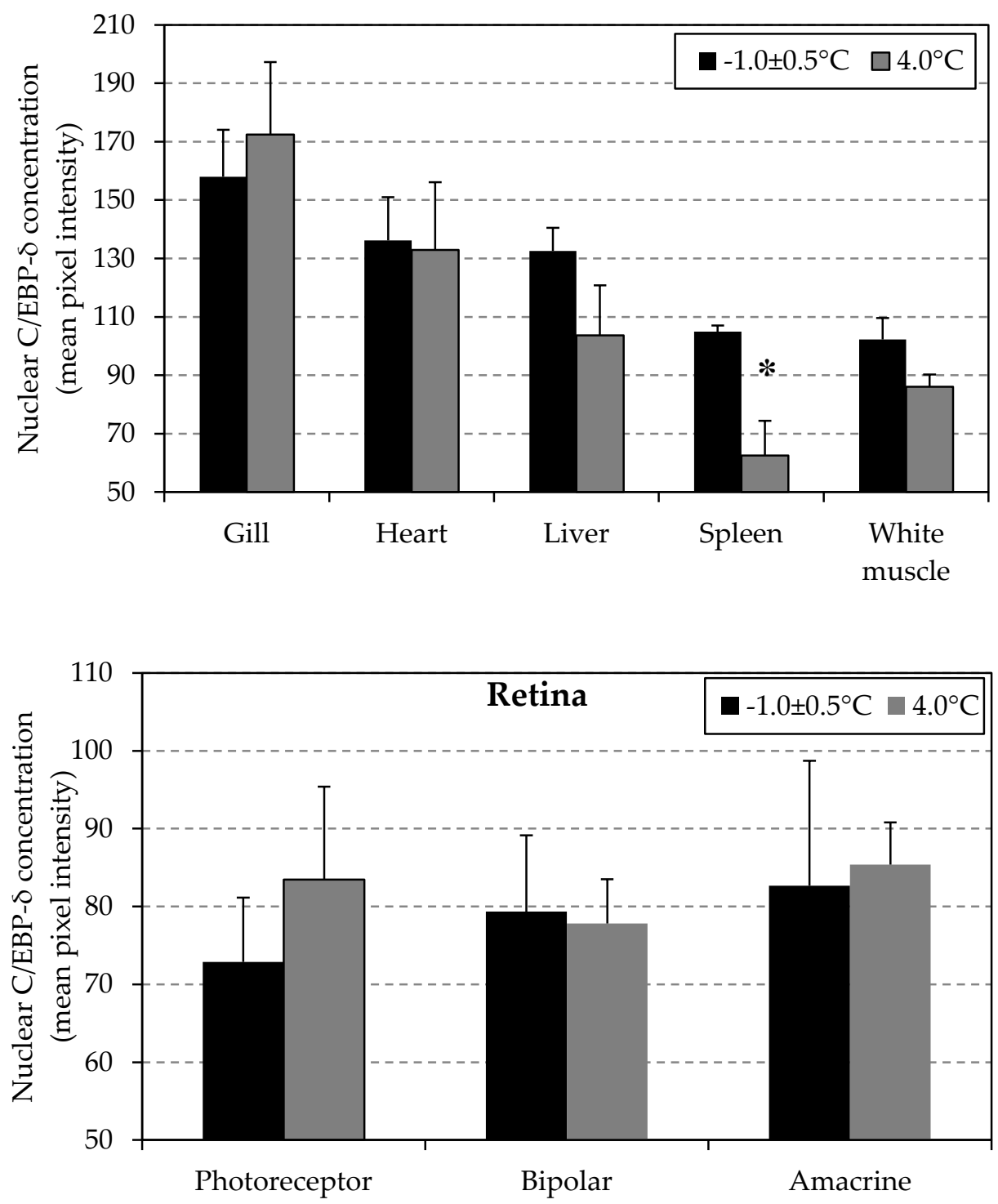
Figure 23. Nuclear C/EBP- $\delta$ concentrations in Pagothenia borchgrevinki tissues following $168 \mathrm{~h}$ of heat stress. Data are presented as mean pixel intensity + SEM. *Means are statistically different (Student's $t$ test; $p=0.0518$ ). Each tissue type was run on a separate slide. Levels are not relative to an internal standard and should not be compared.
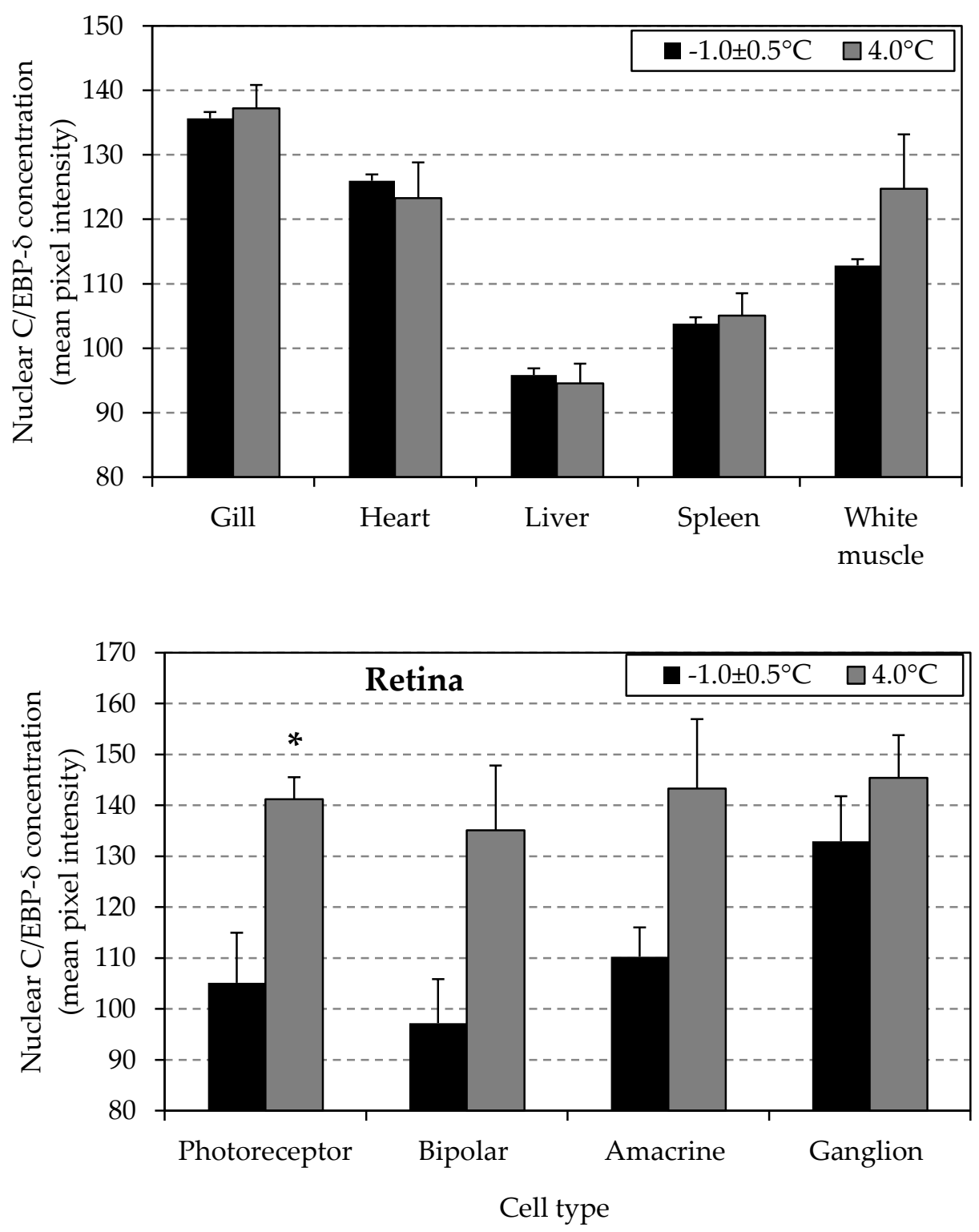
Figure 24. C/EBP- $\delta$ DAB IHC of brain tissue from 6 individual Pagothenia borchgrevinki held at $-1.0 \pm 0.5^{\circ} \mathrm{C}$ (left panels) or $4.0^{\circ} \mathrm{C}$ (right panels) for $168 \mathrm{hrs}$ (acquired at 200X magnification).

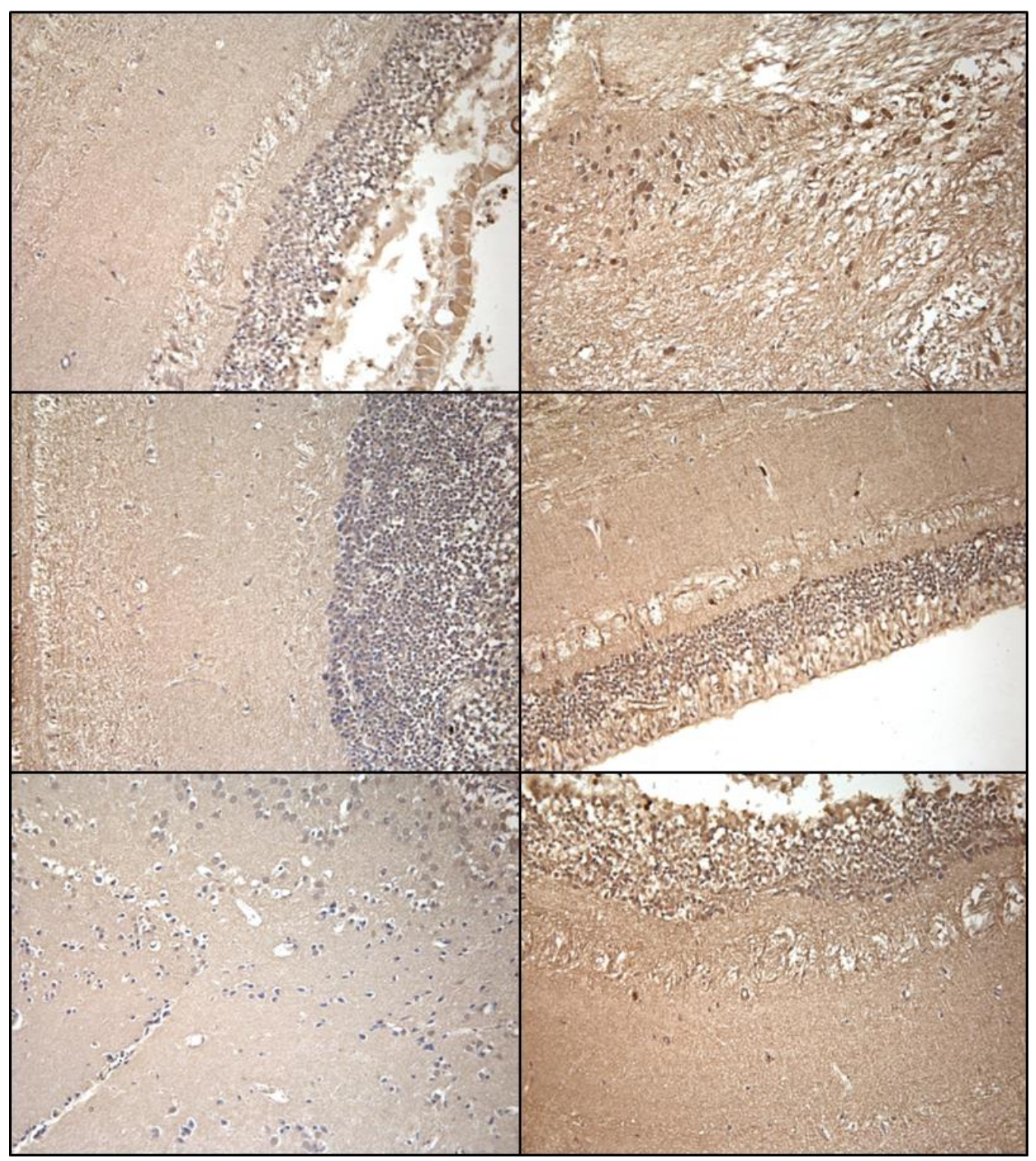


Figure 25. C/EBP- $\delta$ DAB IHC of brain tissue from 6 individual Pagothenia borchgrevinki held at $-1.0 \pm 0.5^{\circ} \mathrm{C}$ (left panels) or $4.0^{\circ} \mathrm{C}$ (right panels) for $168 \mathrm{hrs}$ (acquired at 400X magnification).

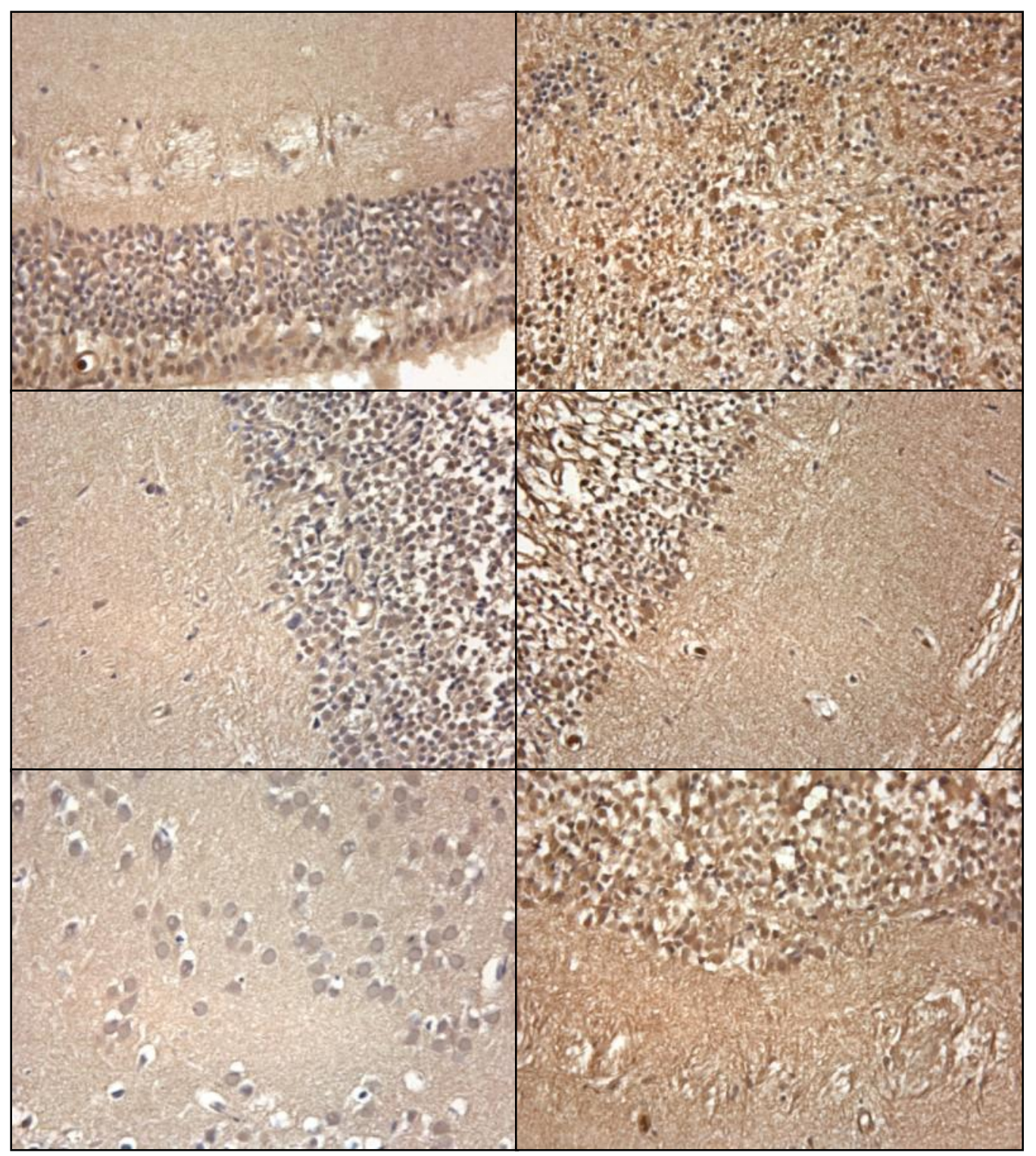


Figure 26. C/EBP- $\delta$ DAB IHC of retinae from 6 individual Pagothenia borchgrevinki held at $-1.0 \pm 0.5^{\circ} \mathrm{C}$ (left panels) or $4.0^{\circ} \mathrm{C}$ (right panels)for $168 \mathrm{hrs}$ (acquired at 200X magnification).

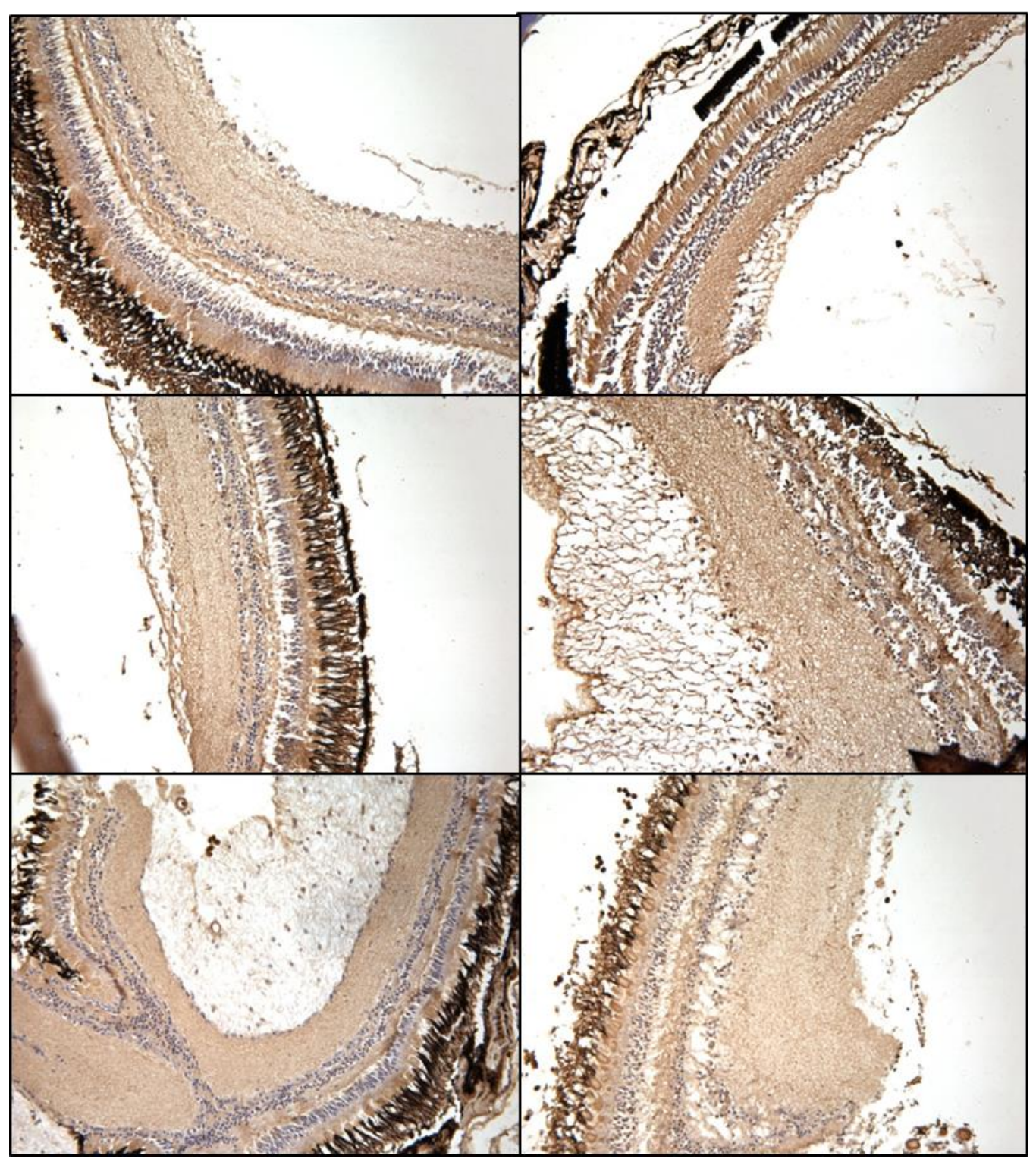


Figure 27. C/EBP- $\delta$ DAB IHC of retinae from 6 individual Pagothenia borchgrevinki held at $-1.0 \pm 0.5^{\circ} \mathrm{C}$ (left panels) or $4.0^{\circ} \mathrm{C}$ (right panels) for $168 \mathrm{hrs}$ (acquired at 400X magnification).

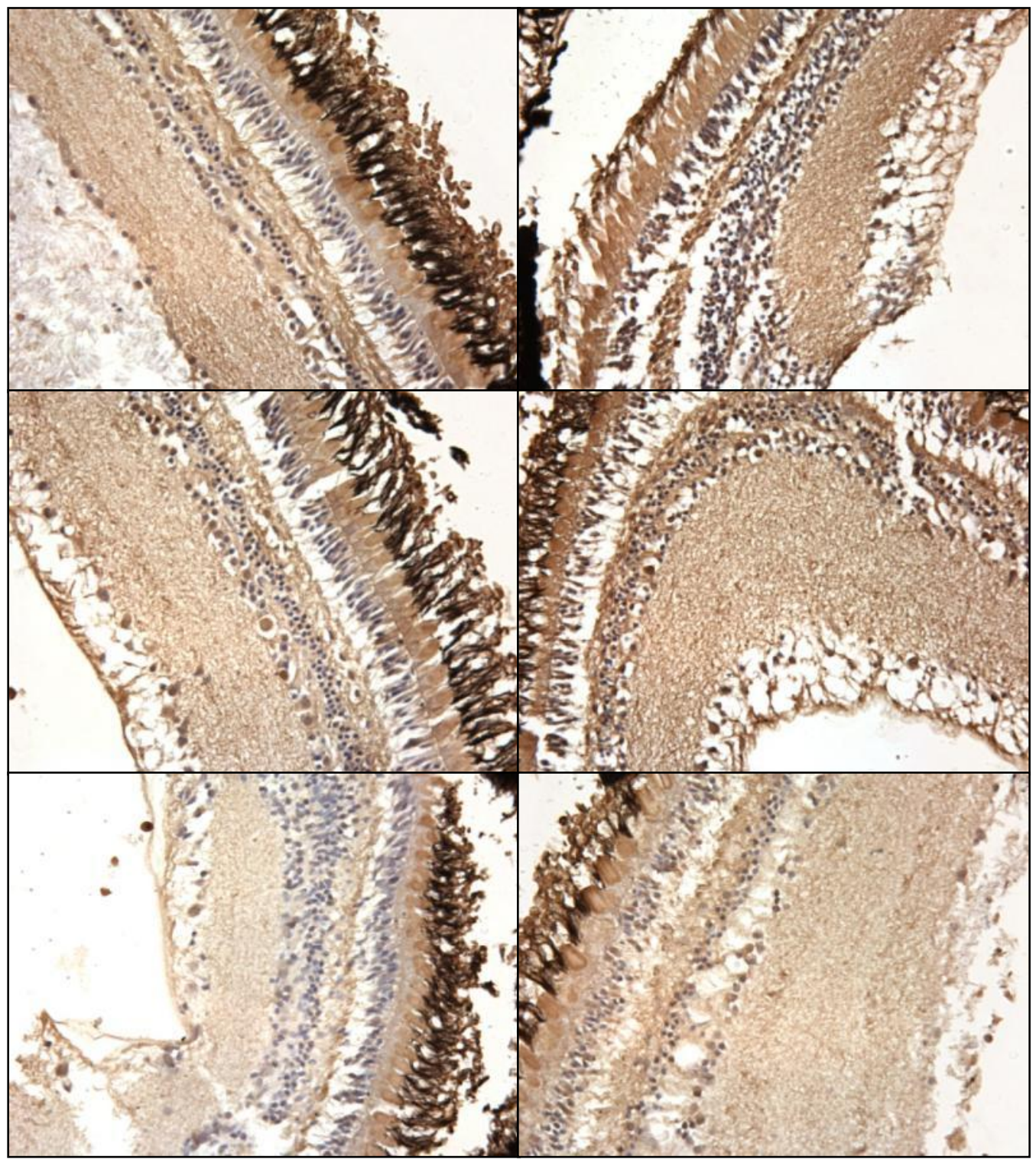


Figure 28. C/EBP-ठ DAB IHC of gill tissue from 6 individual Pagothenia borchgrevinki held at $-1.0 \pm 0.5^{\circ} \mathrm{C}$ (left panels) or $4.0^{\circ} \mathrm{C}$ (right panels) for $168 \mathrm{hrs}$ (acquired at 200X magnification). Note the dark staining of endothelial cells, smoothe muscle cells and chondrocytes.

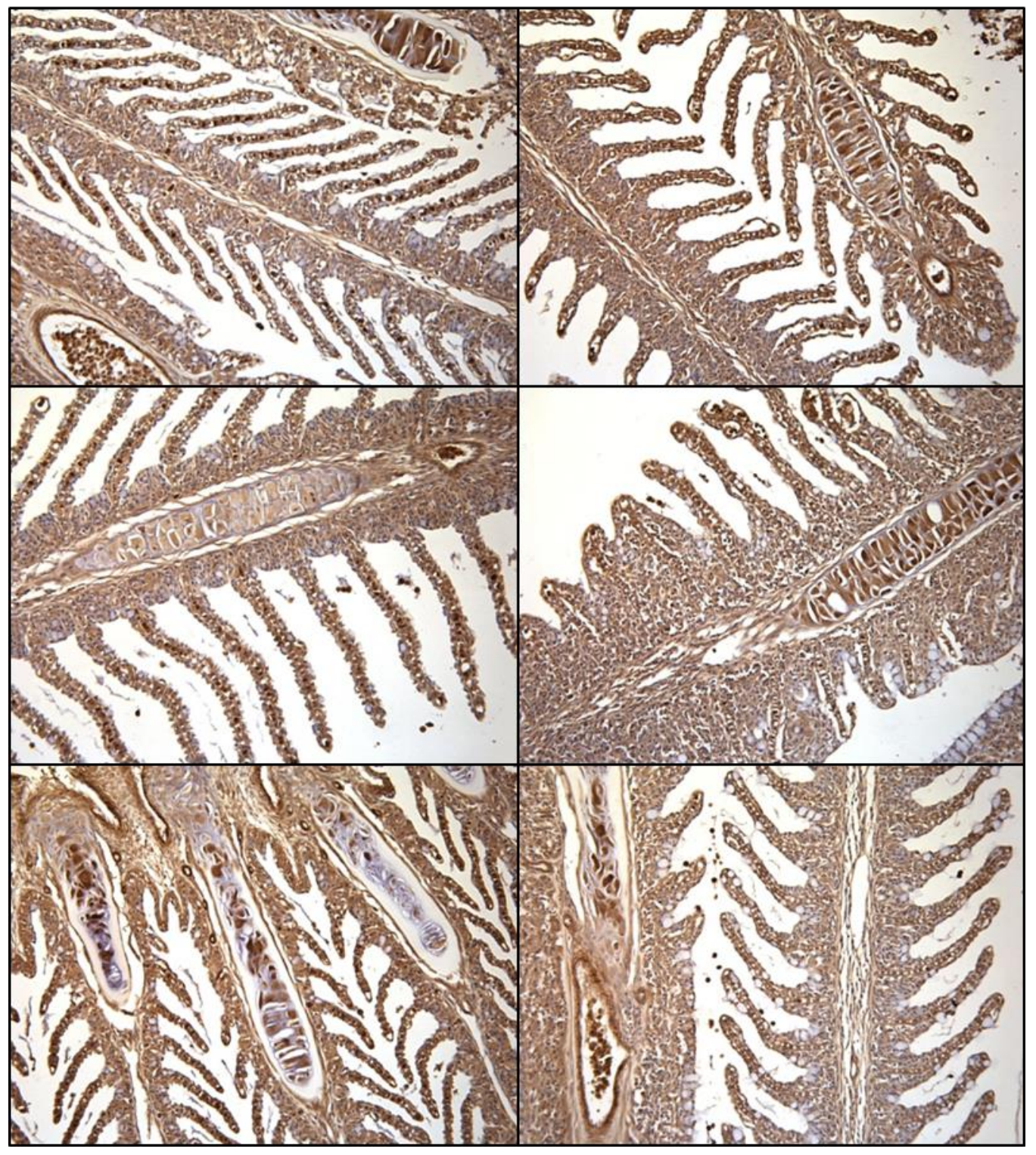


Figure 29. C/EBP- $\delta$ DAB IHC of gill tissue from 6 individual Pagothenia borchgrevinki held at $-1.0 \pm 0.5^{\circ} \mathrm{C}$ (left panels) or $4.0^{\circ} \mathrm{C}$ (right panels) for $168 \mathrm{hrs}$ (acquired at 400X magnification).

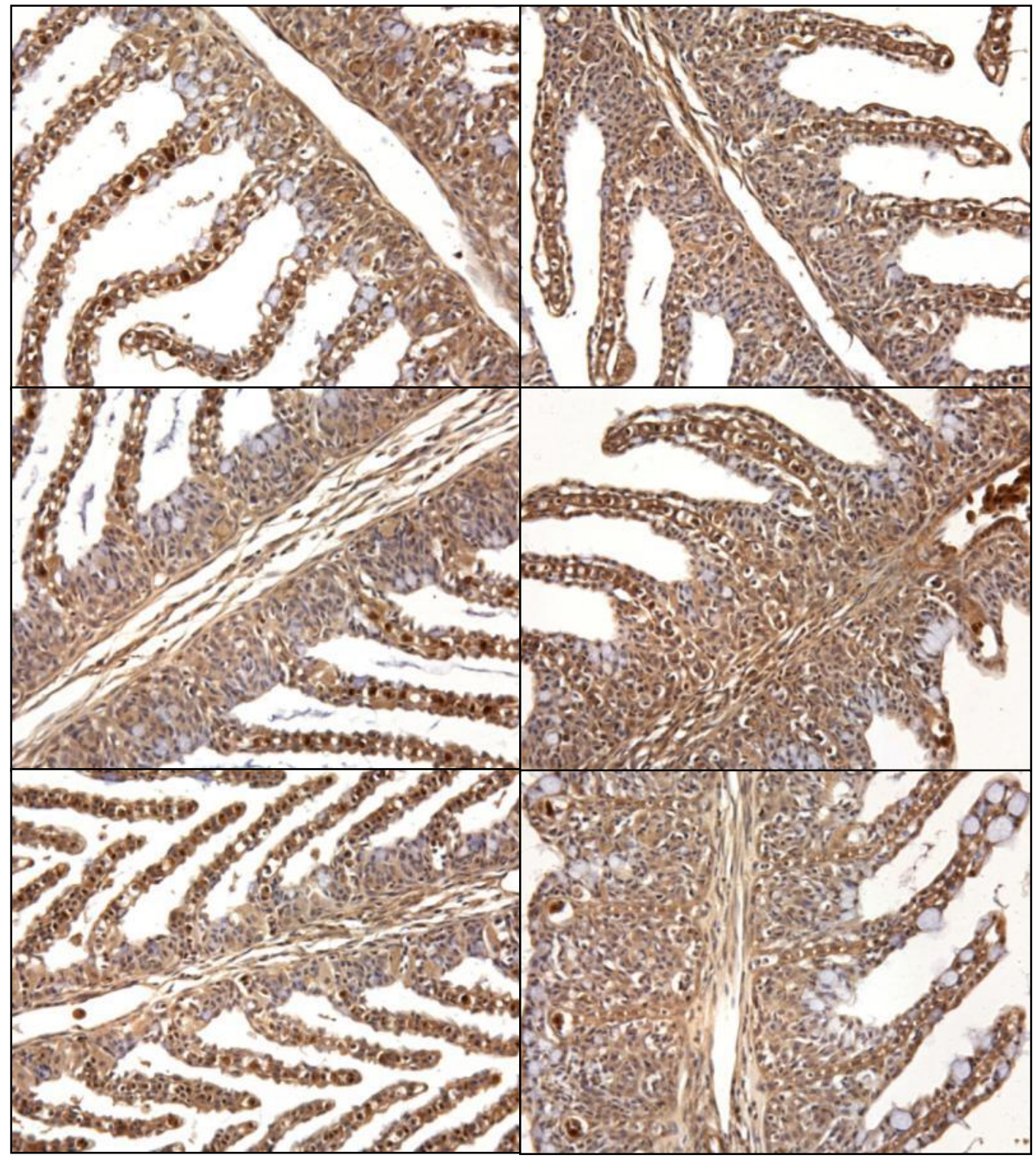


Figure 30. C/EBP- $\delta$ DAB IHC of heart tissue from 6 individual Pagothenia borchgrevinki held at $-1.0 \pm 0.5^{\circ} \mathrm{C}$ (left panels) or $4.0^{\circ} \mathrm{C}$ (right panels) for $168 \mathrm{hrs}$ (acquired at 200X magnification). Note that the middle right panel depicts a blood clot in lieu of actual cardiac muscle tissue.

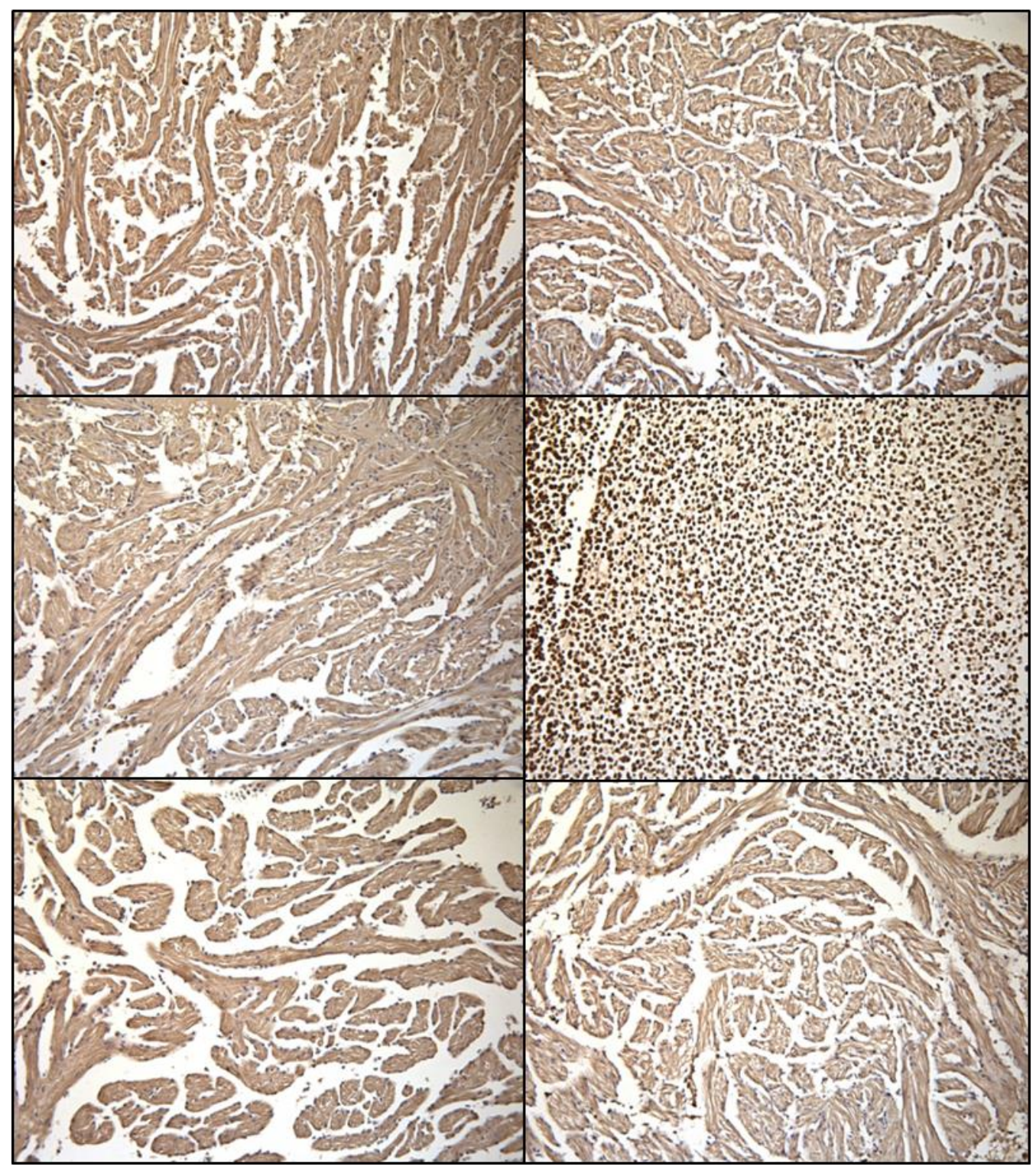


Figure 31. C/EBP- $\delta$ DAB IHC of heart tissue from 6 individual Pagothenia borchgrevinki held at $-1.0 \pm 0.5^{\circ} \mathrm{C}$ (left panels) or $4.0^{\circ} \mathrm{C}$ (right panels) for $168 \mathrm{hrs}$ (acquired at 400X magnification). Note that the bottom right panel depicts a blood clot in lieu of actual cardiac muscle tissue.

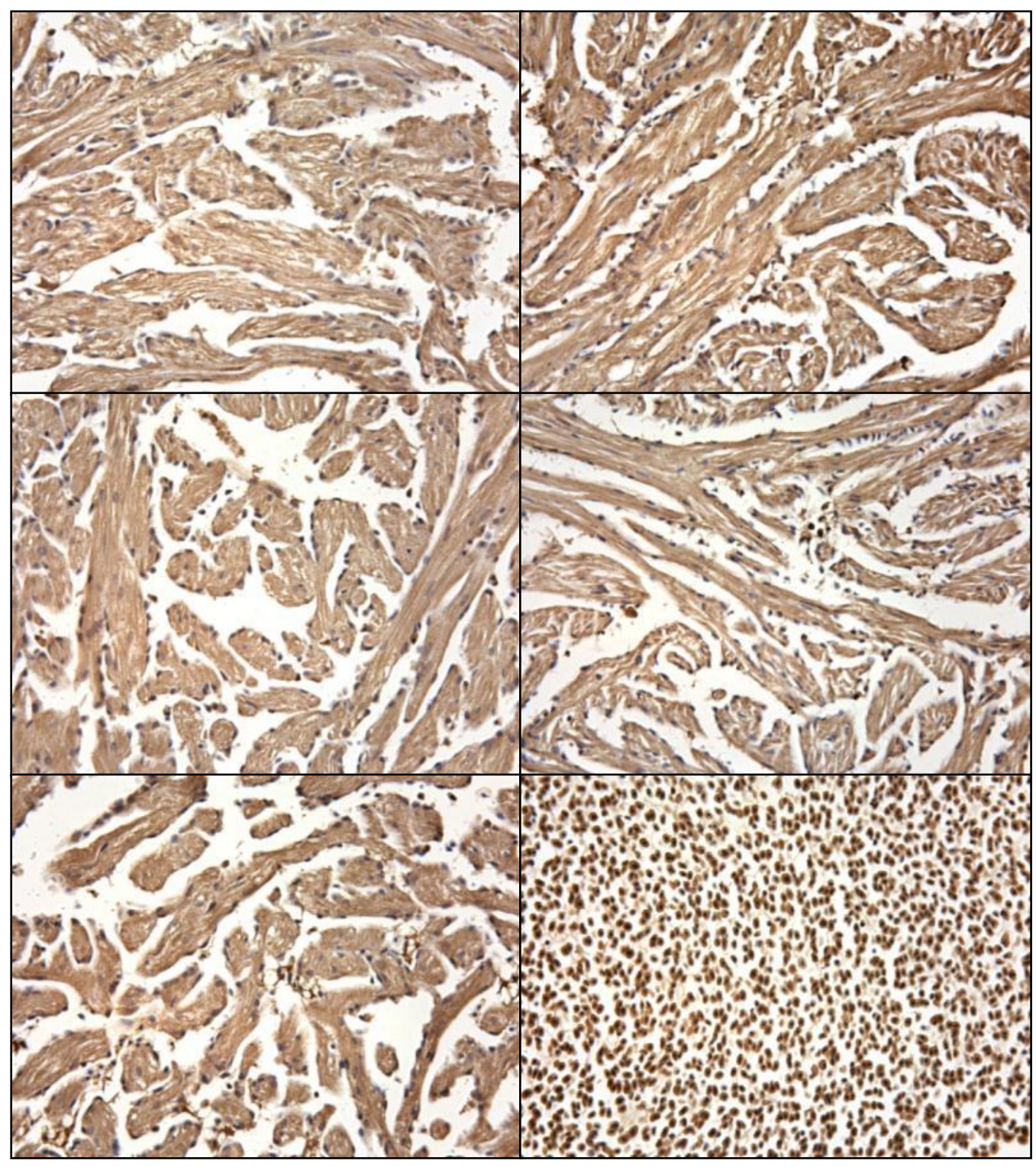


Figure 32. C/EBP- $\delta$ DAB IHC of liver tissue from 6 individual Pagothenia borchgrevinki held at $-1.0 \pm 0.5^{\circ} \mathrm{C}$ (left panels) or $4.0^{\circ} \mathrm{C}$ (right panels) for $168 \mathrm{hrs}$ (acquired at 200X magnification).

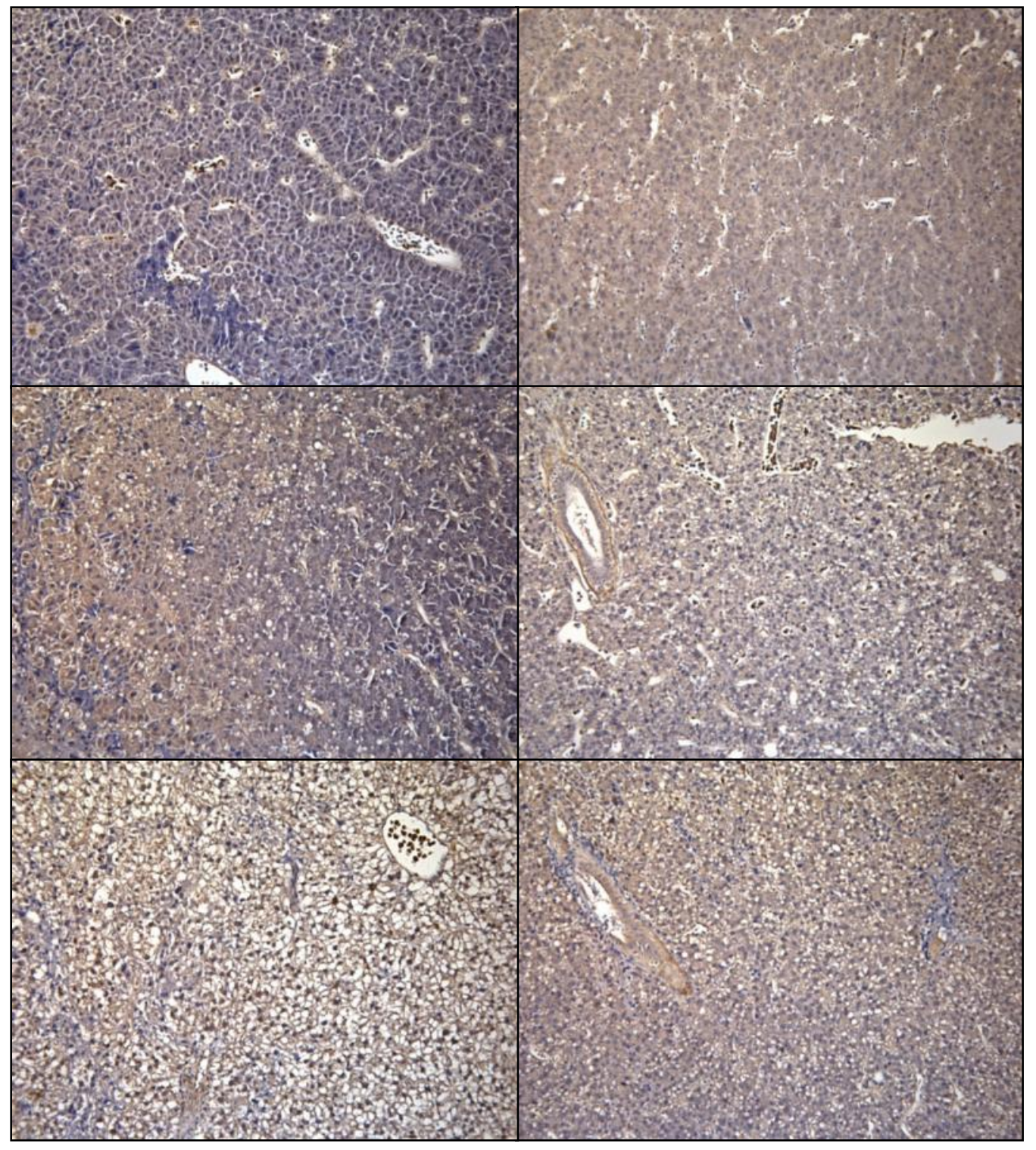


Figure 33. C/EBP- $\delta$ DAB IHC of liver tissue from 6 individual Pagothenia borchgrevinki held at $-1.0 \pm 0.5^{\circ} \mathrm{C}$ (left panels) or $4.0^{\circ} \mathrm{C}$ (right panels) for $168 \mathrm{hrs}$ (acquired at 400X magnification).

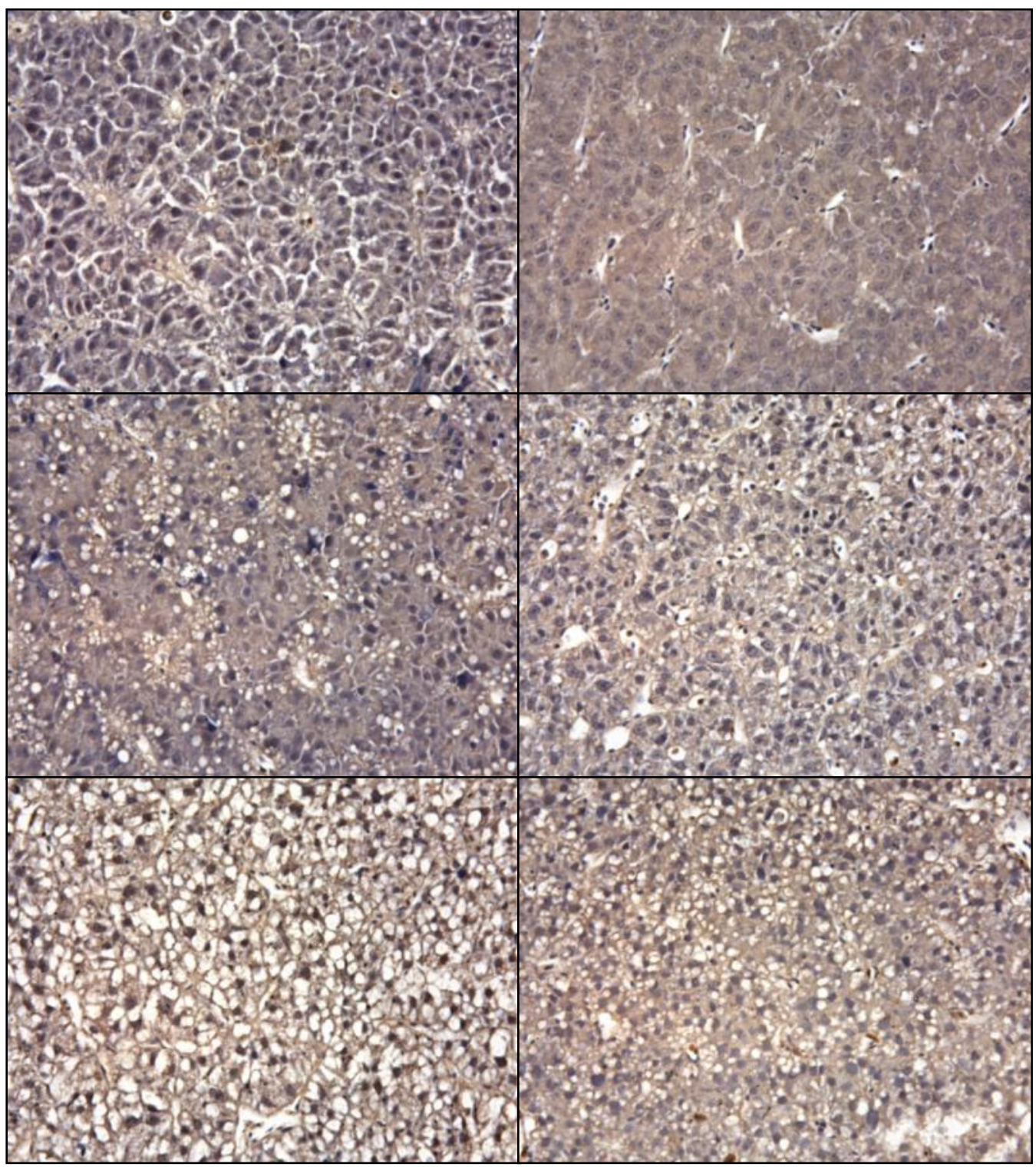


Figure 34. C/EBP- $\delta$ DAB IHC of spleen tissue from 6 individual Pagothenia borchgrevinki held at $-1.0 \pm 0.5^{\circ} \mathrm{C}$ (left panels) or $4.0^{\circ} \mathrm{C}$ (right panels) for $168 \mathrm{hrs}$ (acquired at 200X magnification).

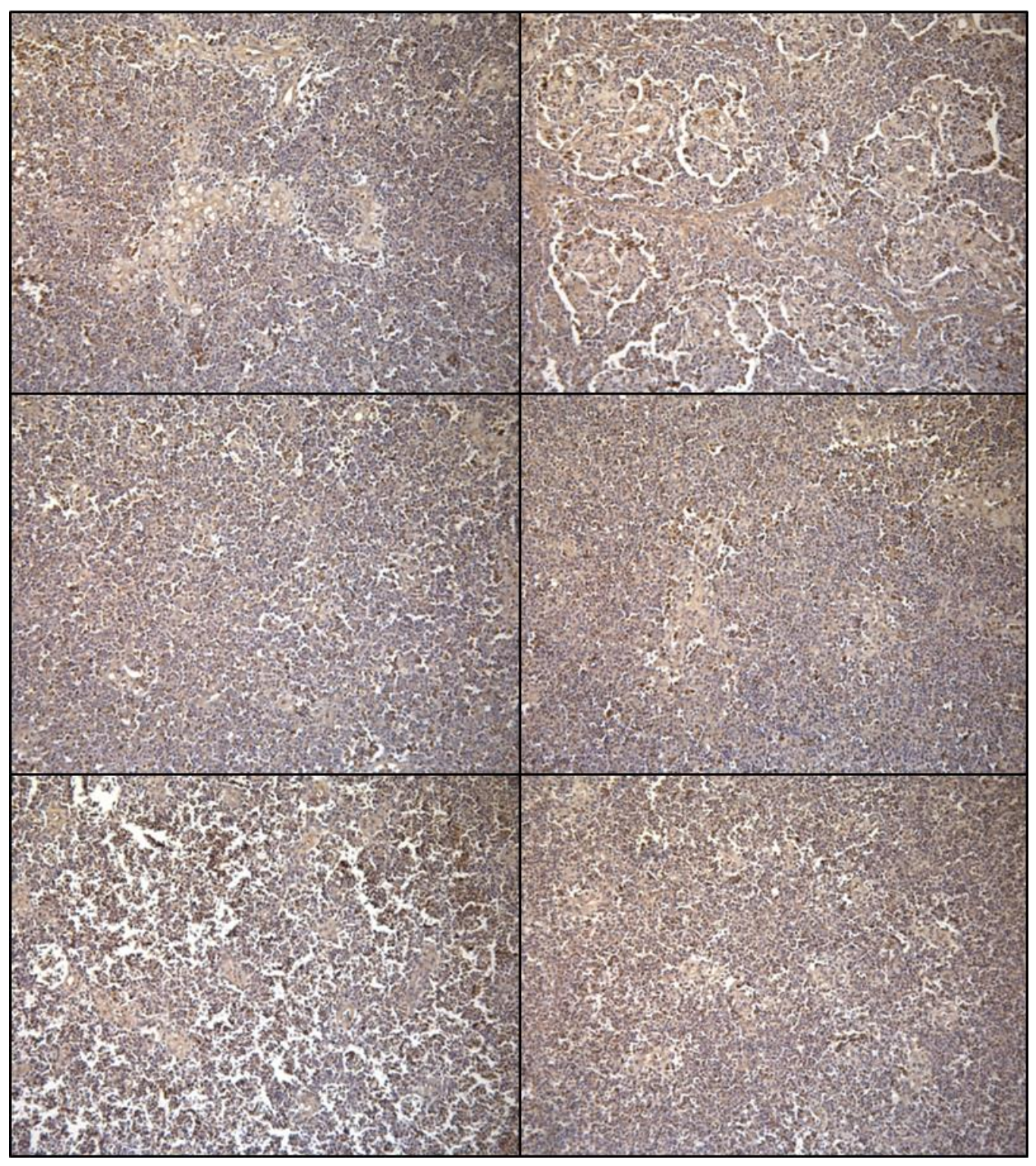


Figure 35. C/EBP- $\delta$ DAB IHC of spleen tissue from 6 individual Pagothenia borchgrevinki held at $-1.0 \pm 0.5^{\circ} \mathrm{C}$ (left panels) or $4.0^{\circ} \mathrm{C}$ (right panels) for $168 \mathrm{hrs}$ (acquired at 400X magnification).

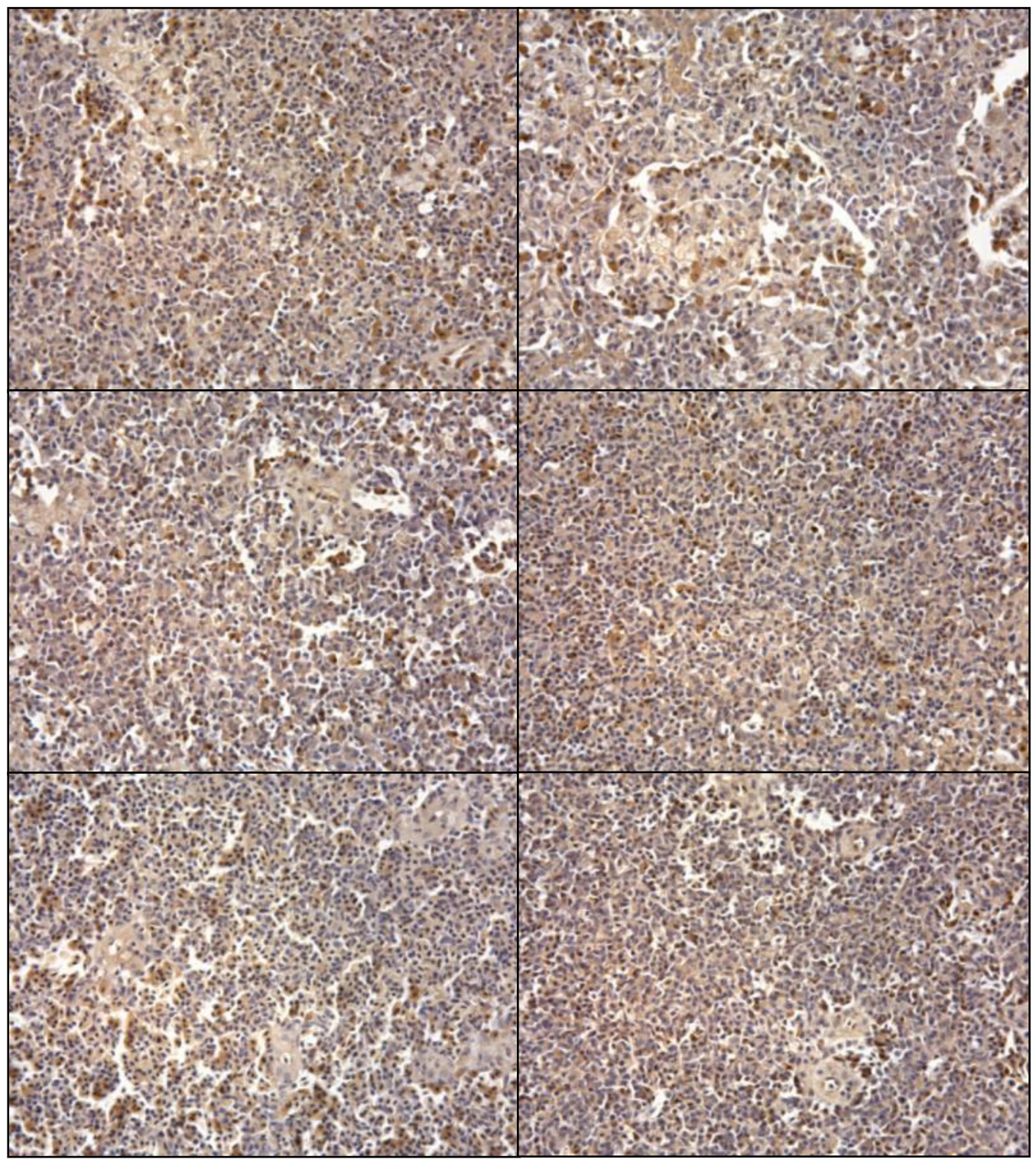


Figure 36. C/EBP- $\delta$ DAB IHC of white muscle tissue from 6 individual Pagothenia borchgrevinki held at $-1.0 \pm 0.5^{\circ} \mathrm{C}$ (left panels) or $4.0^{\circ} \mathrm{C}$ (right panels) for $168 \mathrm{hrs}$ (acquired at 200X magnification).

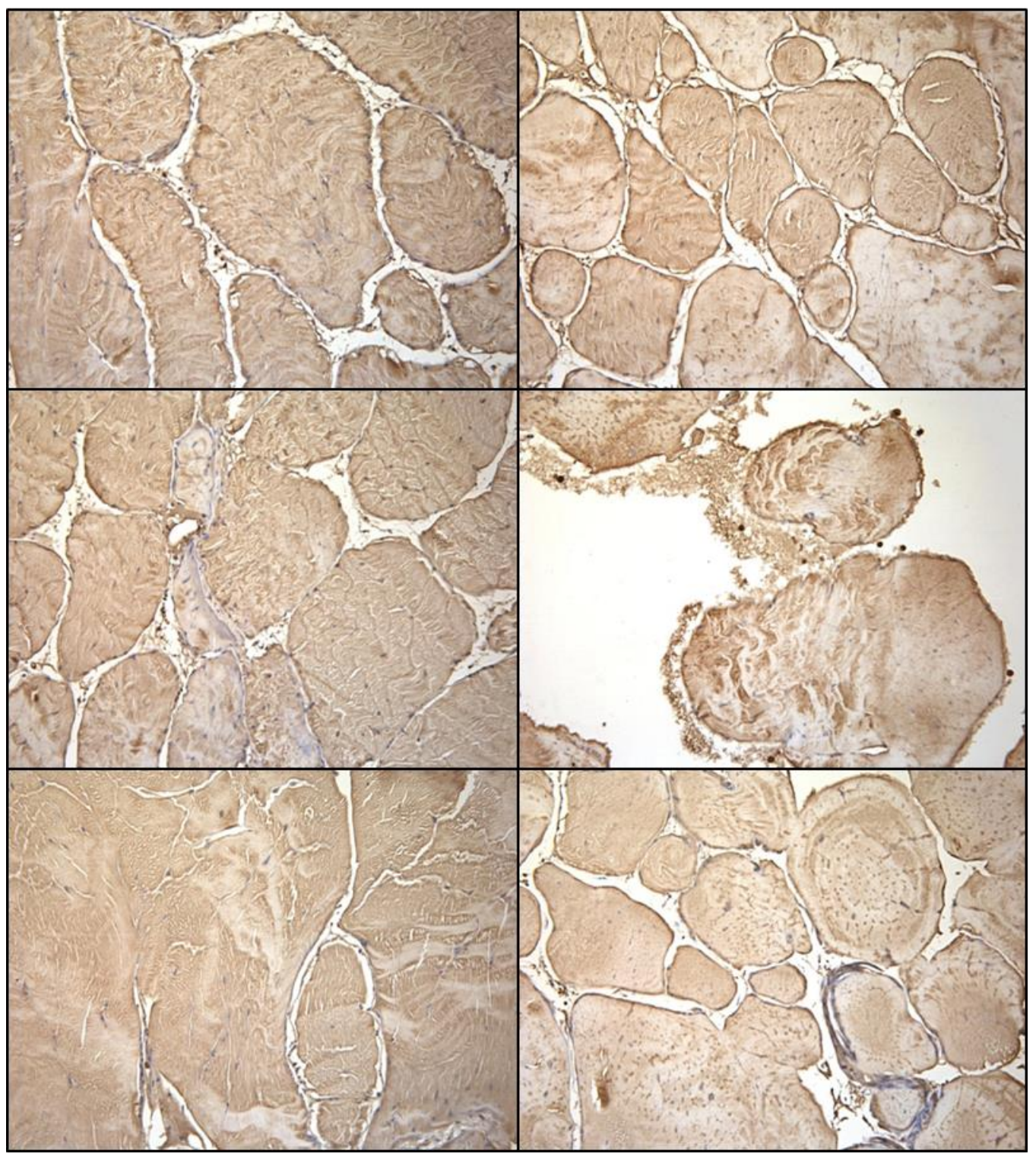


Figure 37. C/EBP- $\delta$ DAB IHC of white muscle tissue from 6 individual Pagothenia borchgrevinki held at $-1.0 \pm 0.5^{\circ} \mathrm{C}$ (left panels) or $4.0^{\circ} \mathrm{C}$ (right panels) for $168 \mathrm{hrs}$ (acquired at 400X magnification).

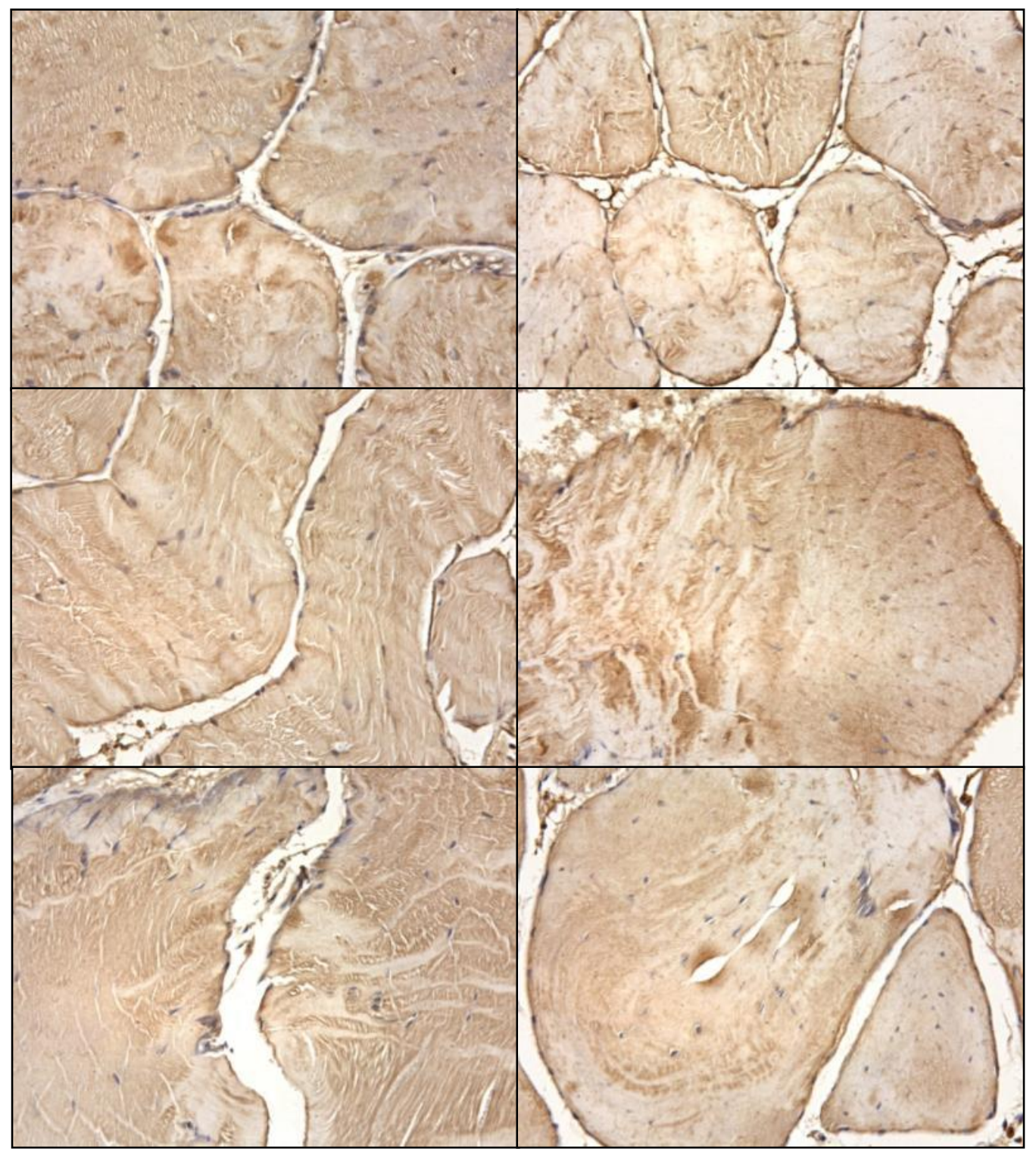


Figure 38. PCNA protein levels in six field-acclimated Trematomus bernacchii ( $n=3$ for heart). Tissue type had a highly significant effect on PCNA concentration (ANOVA; $p<0.0001$ ). Interindividual variation was nearly significant (ANOVA; $p=0.0624$ ). PCNA was not detected in white muscle tissue. ${ }^{* * *}$ Spleen differed from all other tissue types, and *gill differed from brain and white muscle (Tukey's multiple comparison test). Tissue types were also compared using Student's t tests, and those results are given in table 4.1.

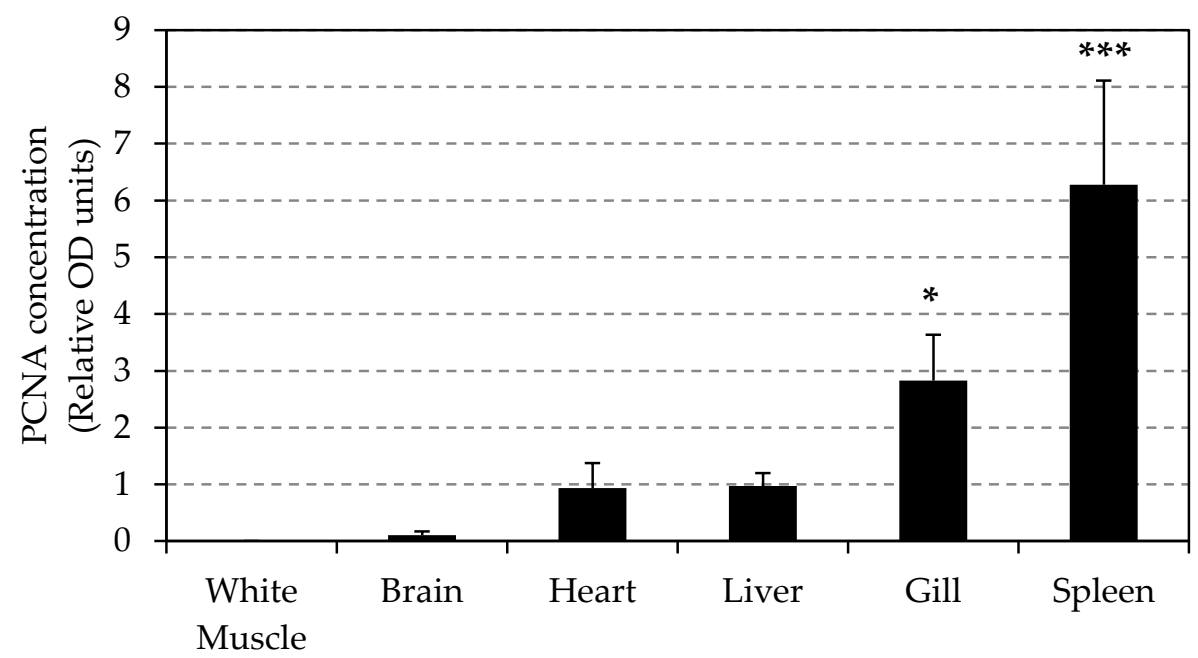

Tissue 
Table 1. $P$ values from paired Student's $t$ tests comparing PCNA protein concentration among tissue types in six field-acclimated Trematomus bernacchii ( $n=3$ for heart). +Unpaired $t$ test yielded a significant result $(n=6 ; p=0.0395)$.

\begin{tabular}{|l|c|c|c|c|c|c|}
\hline & $\begin{array}{c}\text { white } \\
\text { muscle }\end{array}$ & brain & heart & liver & gill & spleen \\
\hline $\begin{array}{l}\text { white } \\
\text { muscle }\end{array}$ & $\mathrm{X}$ & 0.0886 & 0.2295 & $0.0030^{* *}$ & $0.0062^{* *}$ & $0.0070^{* *}$ \\
\hline brain & 0.0886 & $\mathrm{X}$ & 0.2907 & $0.0046^{* *}$ & $0.0053^{* *}$ & $0.0065^{* *}$ \\
\hline heart & 0.2295 & 0.2907 & $\mathrm{X}$ & 0.7415 & 0.2373 & $0.1266+$ \\
\hline liver & $0.0030^{* *}$ & $0.0046^{* *}$ & 0.7415 & $\mathrm{X}$ & $0.0192^{*}$ & $0.0110^{*}$ \\
\hline gill & $0.0062^{* *}$ & $0.0053^{* *}$ & 0.2373 & $0.0192^{*}$ & $\mathrm{X}$ & $0.0086^{* *}$ \\
\hline spleen & $0.0070^{* *}$ & $0.0065^{* *}$ & $0.1266+$ & $0.0110^{*}$ & $0.0086^{* *}$ & $\mathrm{X}$ \\
\hline
\end{tabular}

Table 2. $P$ values from two-way ANOVA for PCNA protein concentration in control $\left(-1.0 \pm 0.5^{\circ} \mathrm{C}\right)$ and heat-stressed $\left(2.0^{\circ} \mathrm{C}\right.$ and $\left.4.0^{\circ} \mathrm{C}\right)$ Trematomus bernacchii sampled at 6, 24, 72 and $168 \mathrm{~h}$ ( $n=3$ at each time/temp point).

\begin{tabular}{|l|r|r|r|}
\hline & interaction & time & temperature \\
\hline gill & 0.3879 & 0.9578 & 0.9031 \\
\hline heart & 0.2538 & 0.5876 & 0.6968 \\
\hline liver & 0.1044 & $0.0109^{*}$ & 0.2968 \\
\hline spleen & 0.1993 & $0.0222^{*}$ & $0.0216^{*}$ \\
\hline
\end{tabular}


Figure 39. PCNA protein concentrations in control $\left(-1.0 \pm 0.5^{\circ} \mathrm{C}\right)$ and heatstressed $\left(2.0^{\circ} \mathrm{C}\right.$ and $\left.4.0^{\circ} \mathrm{C}\right)$ Trematomus bernacchii heart. Bonferroni posttest revealed no significant differences between columns.

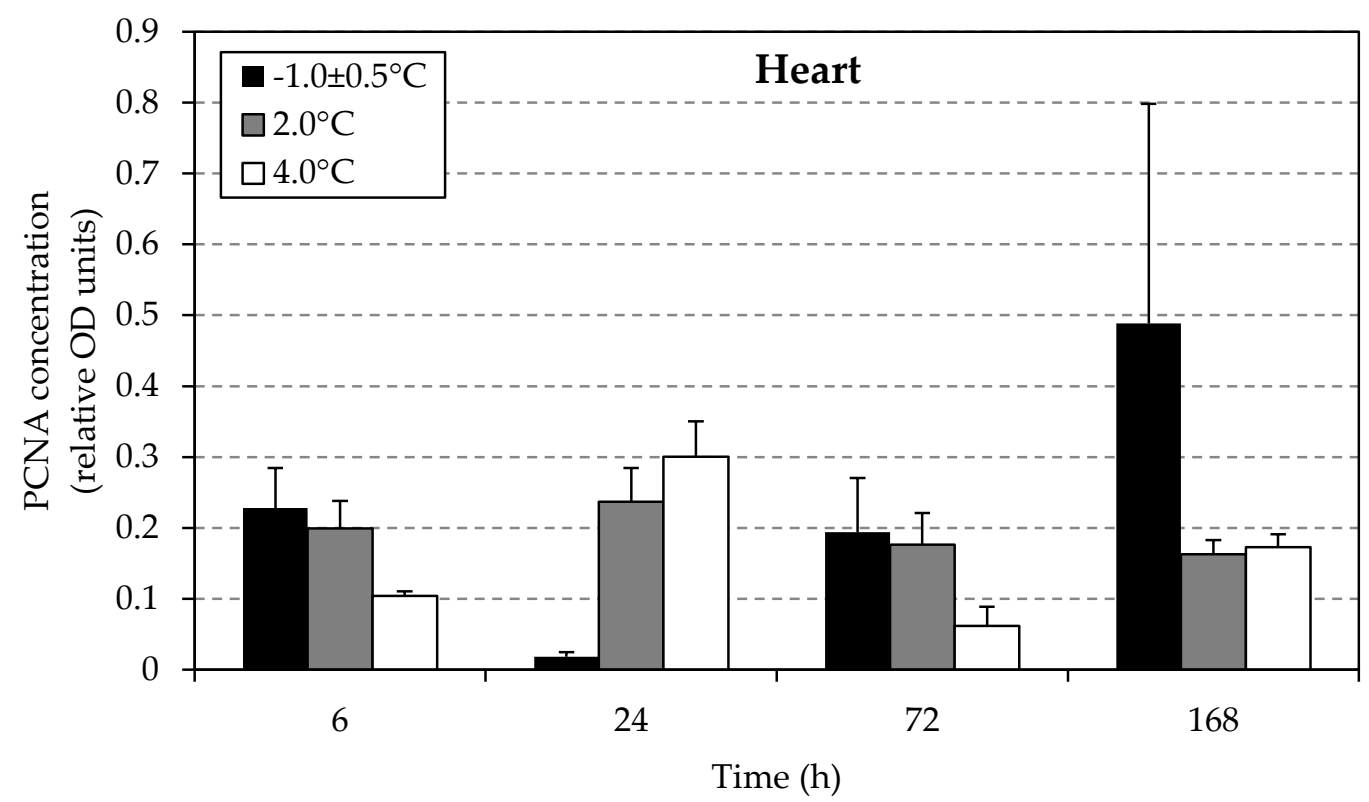


Figure 40. PCNA protein concentrations in control $\left(-1.0 \pm 0.5^{\circ} \mathrm{C}\right)$ and heatstressed $\left(2.0^{\circ} \mathrm{C}\right.$ and $\left.4.0^{\circ} \mathrm{C}\right)$ Trematomus bernacchii liver.

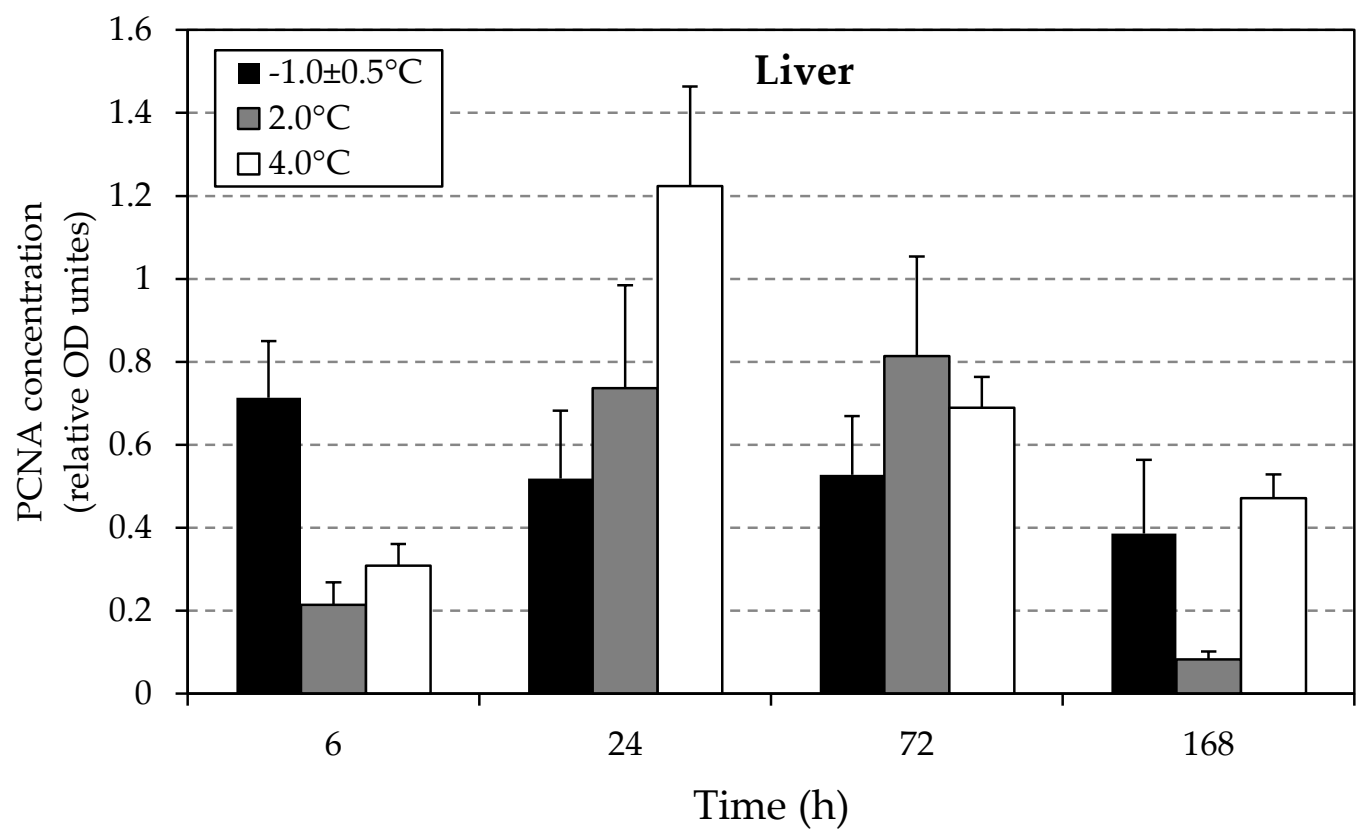


Figure 41. PCNA protein concentrations in control $\left(-1.0 \pm 0.5^{\circ} \mathrm{C}\right)$ and heatstressed $\left(2.0^{\circ} \mathrm{C}\right.$ and $\left.4.0^{\circ} \mathrm{C}\right)$ Trematomus bernacchii gill.

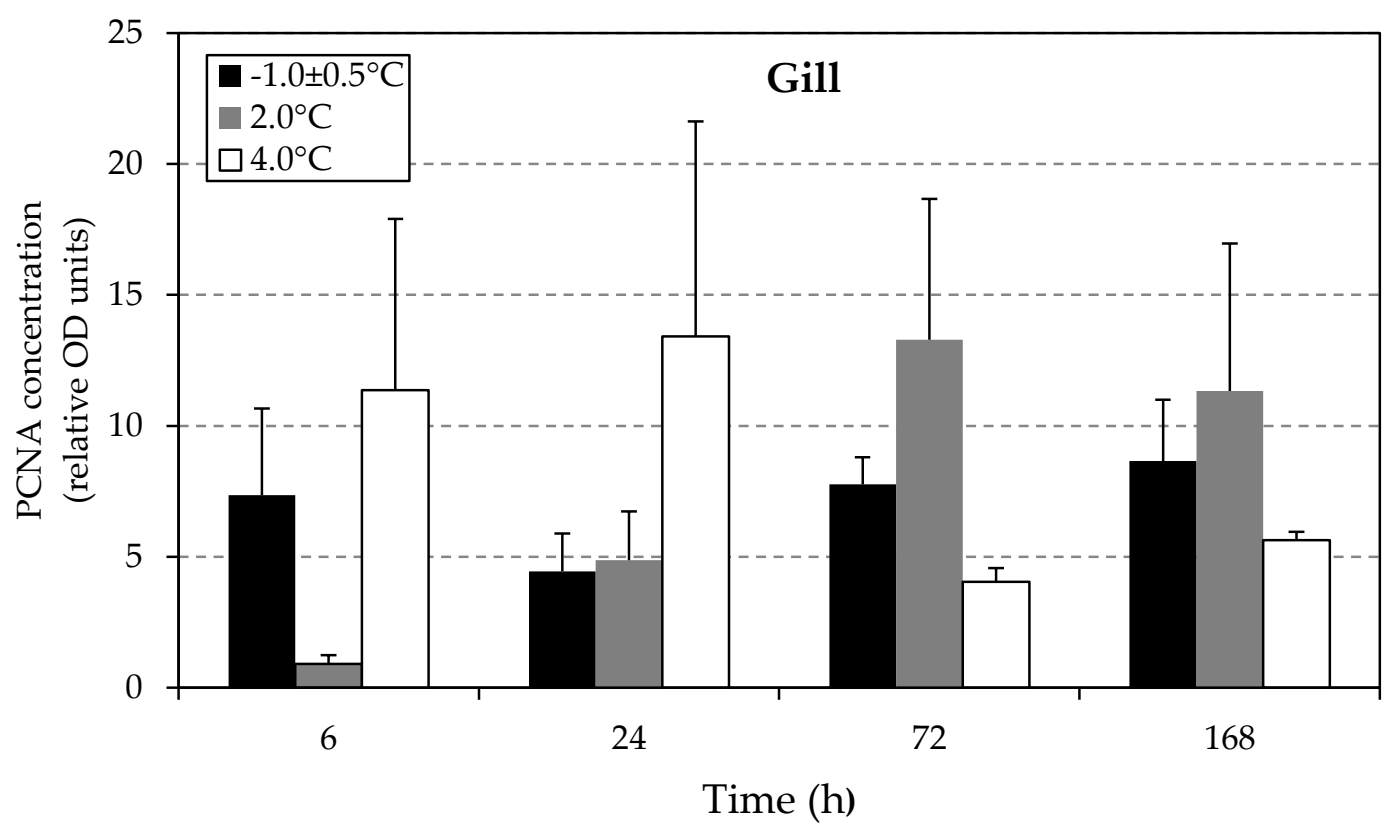


Figure 42. PCNA protein concentrations in control $\left(-1.0 \pm 0.5^{\circ} \mathrm{C}\right)$ and heatstressed $\left(2.0^{\circ} \mathrm{C}\right.$ and $\left.4.0^{\circ} \mathrm{C}\right)$ Trematomus bernacchii spleen. Temperature had a significant effect on PCNA protein concentration (two-way ANOVA; $F=4.519$; $p<0.05)$. ${ }^{*}$ Significantly different than $72 \mathrm{~h}-1.0 \pm 0.5^{\circ} \mathrm{C}$ sample point (Bonferroni posttest; $p<0.05)$.

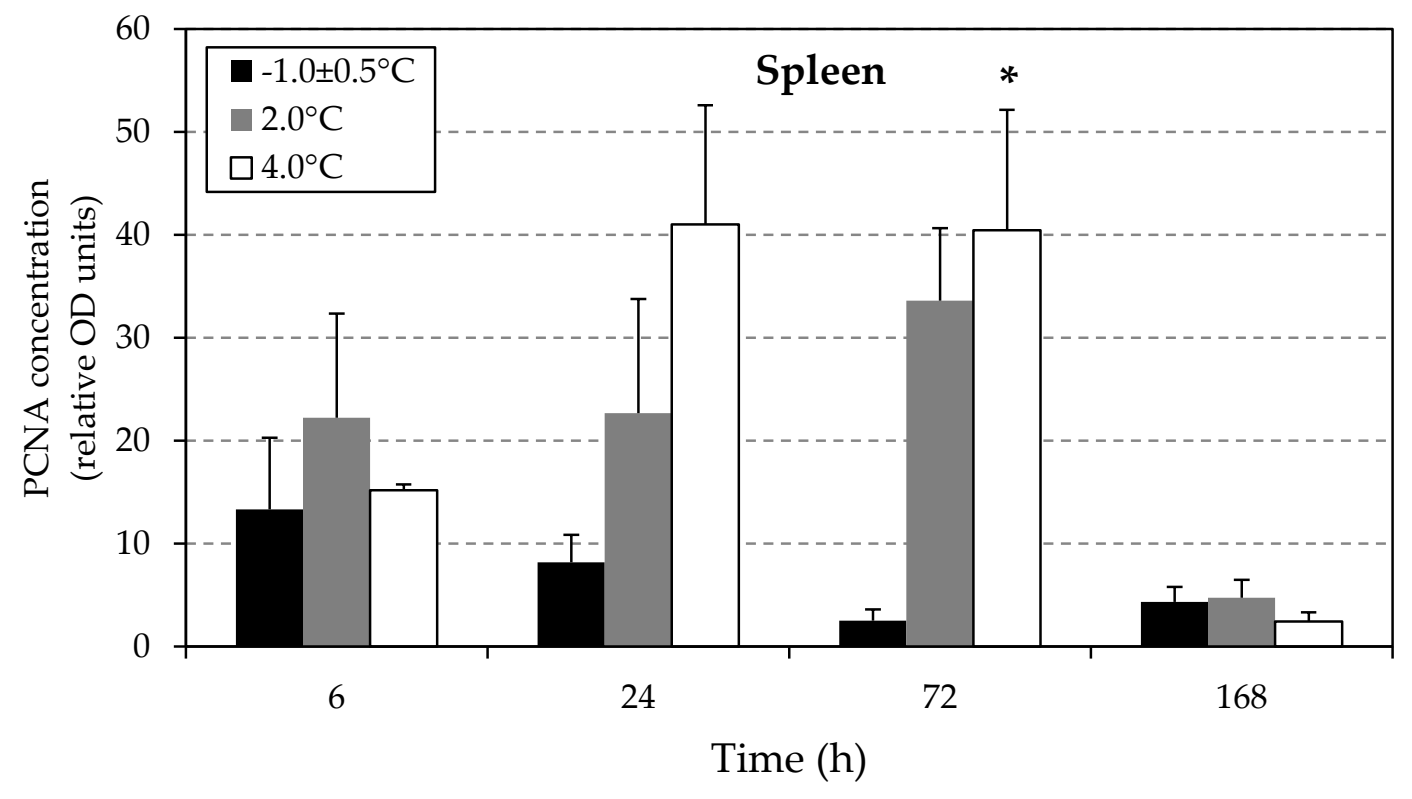


Figure 43. PCNA protein concentration versus body mass for six Trematomus bernacchii held at $-1.0 \pm 0.5^{\circ} \mathrm{C}$ for $72 \mathrm{~h}$ (triangles) or $168 \mathrm{~h}$ (squares).
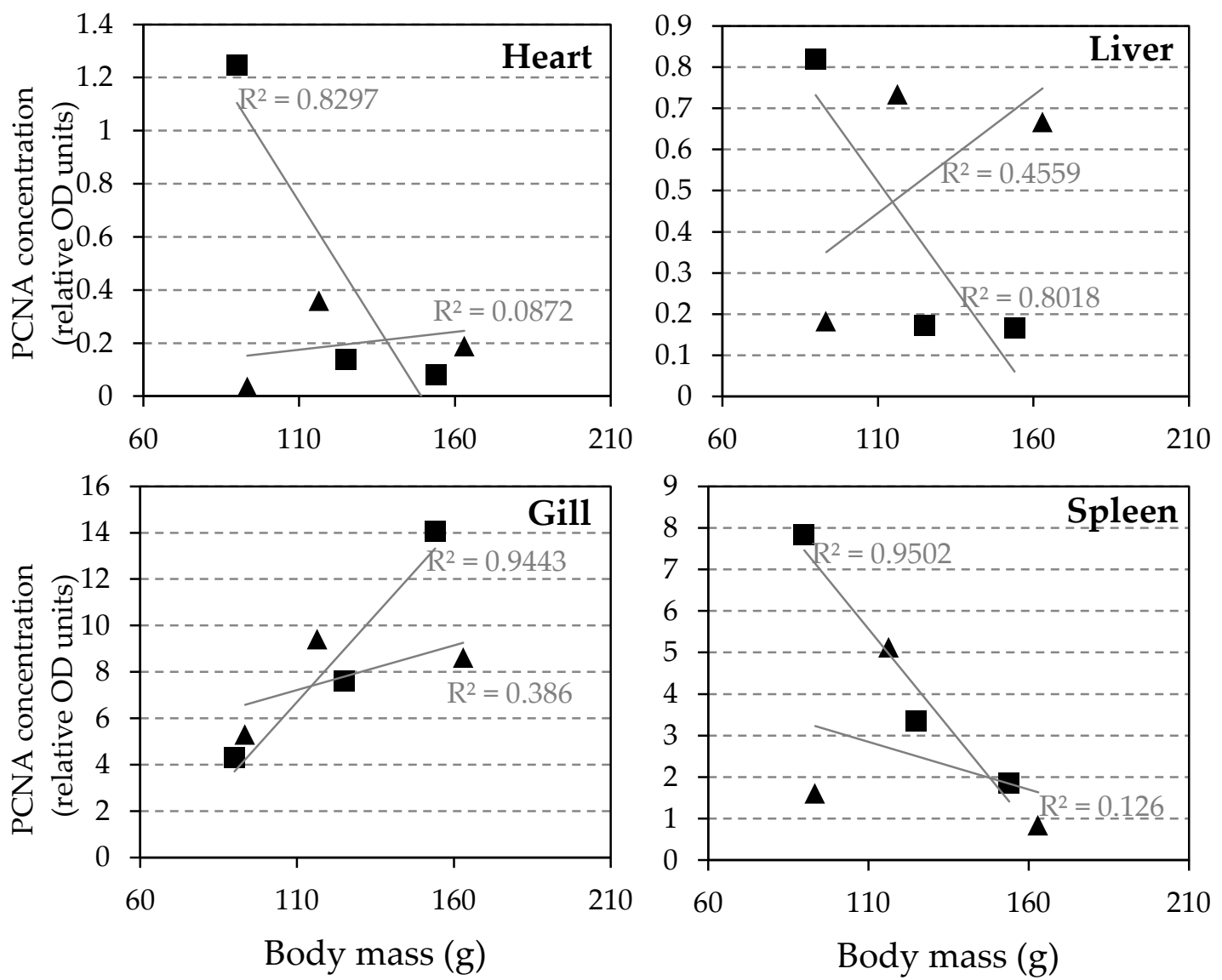
Figure 44. PCNA protein concentration versus body mass for six Trematomus bernacchii held at $2.0^{\circ} \mathrm{C}$ for $72 \mathrm{~h}$ (triangles) or $168 \mathrm{~h}$ (squares).
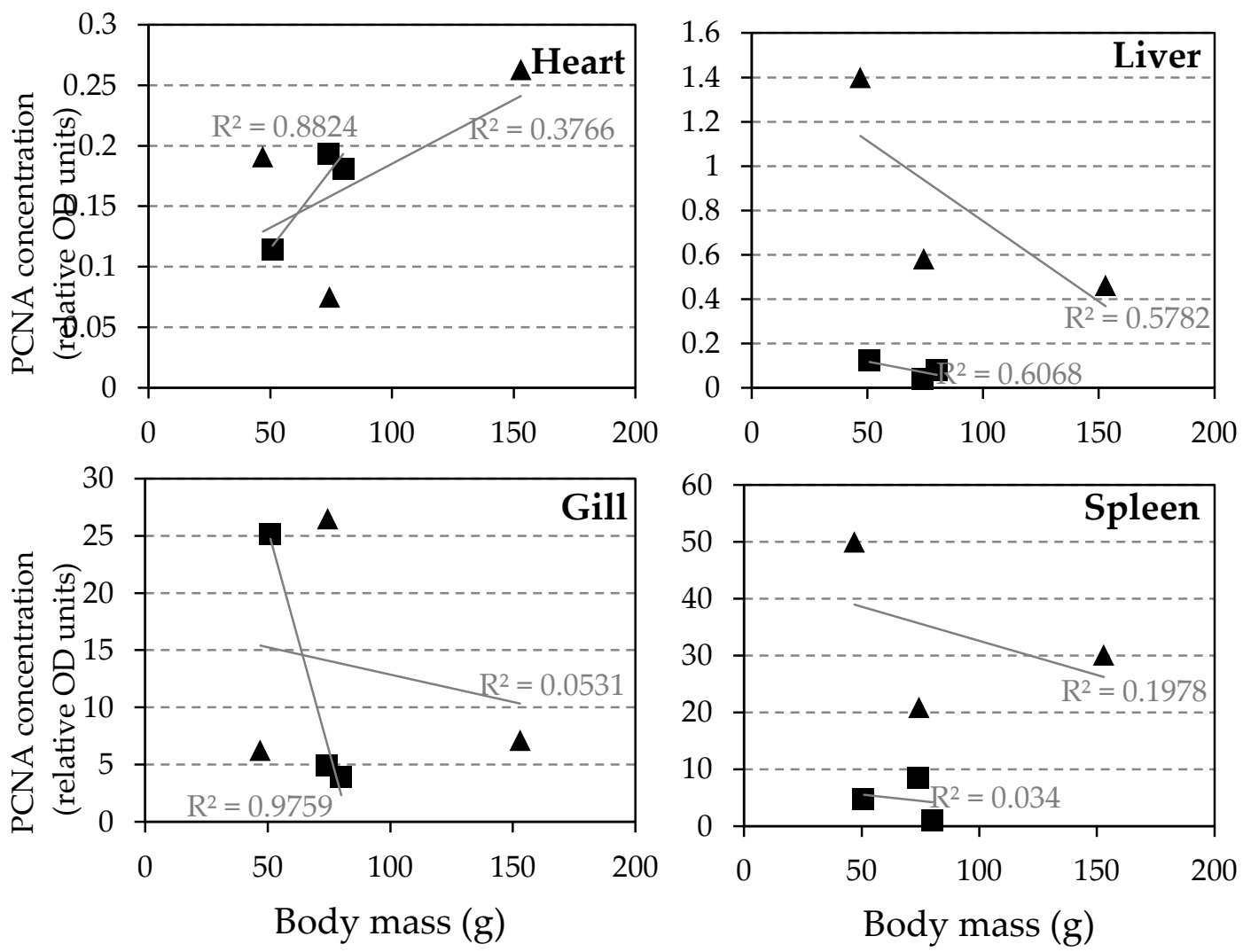
Figure 45. PCNA protein concentration versus body mass for six Trematomus bernacchii held at $4.0^{\circ} \mathrm{C}$ for $72 \mathrm{~h}$ (triangles) or $168 \mathrm{~h}$ (squares).
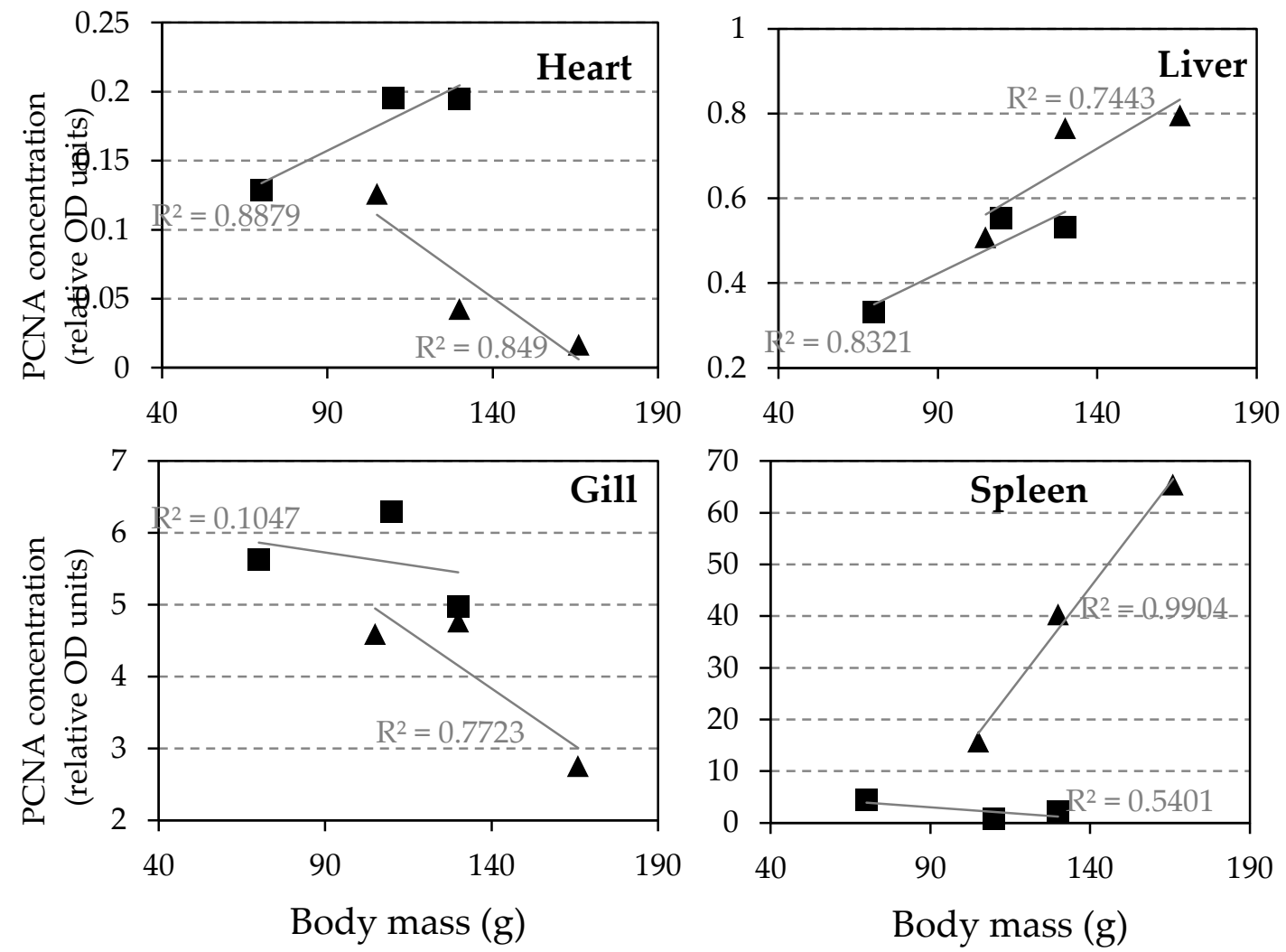
Figure 46. Comparison of C/EBP- $\delta$ and PCNA protein concentrations in spleen from control Trematomus bernacchii held at $-1.0 \pm 0.5^{\circ} \mathrm{C}$ for up to $168 \mathrm{~h}(n=12)$. tWith this datum excluded, $\mathrm{R}^{2}=0.7681$.

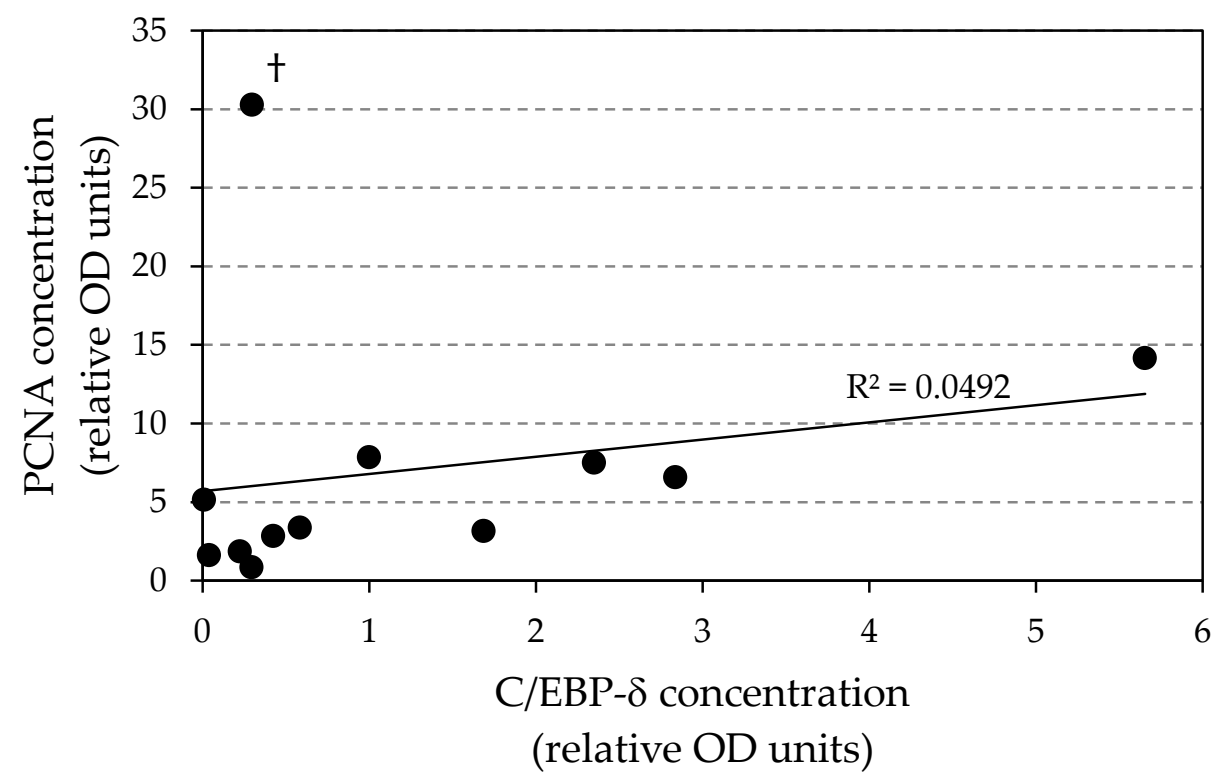


Figure 47. Comparison of C/EBP- $\delta$ and PCNA protein concentration in spleen from control (filled circles) and heat-stressed Trematomus bernacchii sampled at $6 \mathrm{~h}$ (squares), $24 \mathrm{~h}$ (triangles), $72 \mathrm{~h}$ (exes) or $168 \mathrm{~h}$ (open circles). A. Top panel: $2.0^{\circ} \mathrm{C}$ treatment group $(n=11)$ and $-1.0 \pm 0.5^{\circ} \mathrm{C}$ control group $(n=12)$. Linear regression is for control animals. One datum from $6 \mathrm{~h} 2.0^{\circ} \mathrm{C}$ group was excluded for readability (coordinates 122,47 ). B. Bottom panel: $4.0^{\circ} \mathrm{C}$ treatment group $(n=12)$ and $-1.0 \pm 0.5^{\circ} \mathrm{C}$ control group $(n=12)$. Linear regression is for control animals.

A.

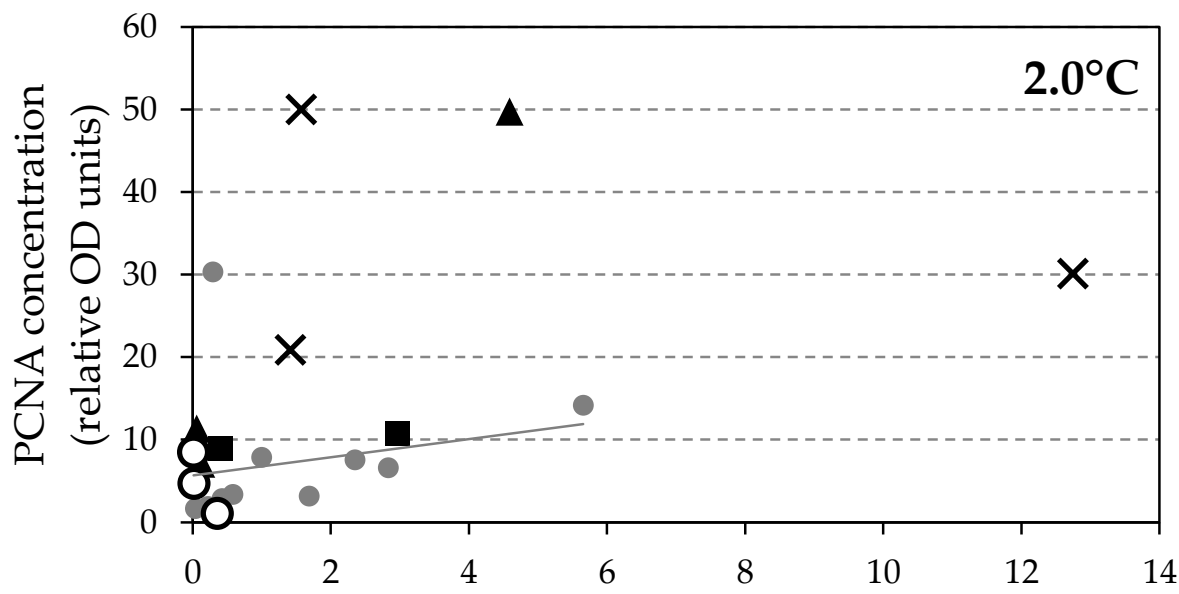

B.

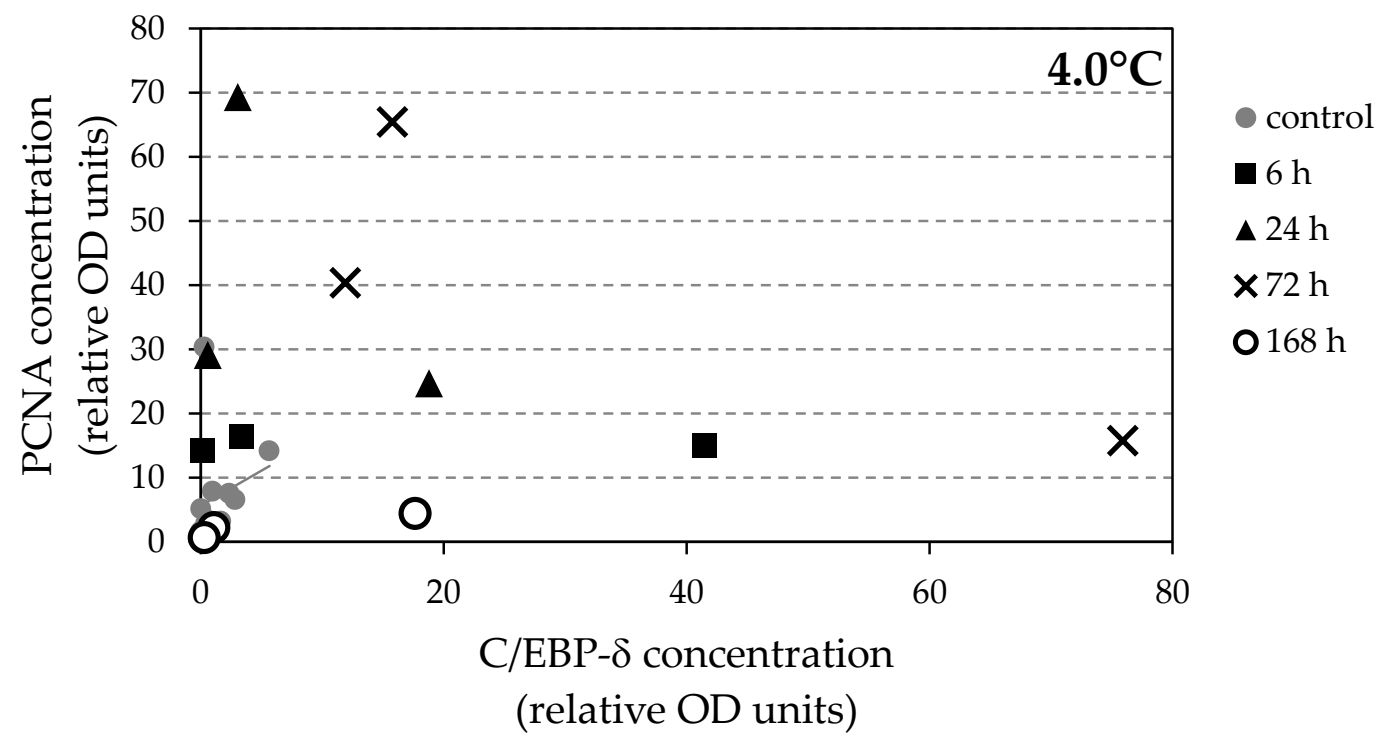


Figure 48. Representative flow cytometry data showing DNA content of Trematomus bernacchii hepatocytes held at $0.0^{\circ} \mathrm{C}$ or $10.0^{\circ} \mathrm{C}$ for up to $24 \mathrm{~h}$. The appearance of a pre-G1 shoulder after 4 to $8 \mathrm{~h}$ at $10^{\circ} \mathrm{C}$ indicates heat induction of apoptosis.
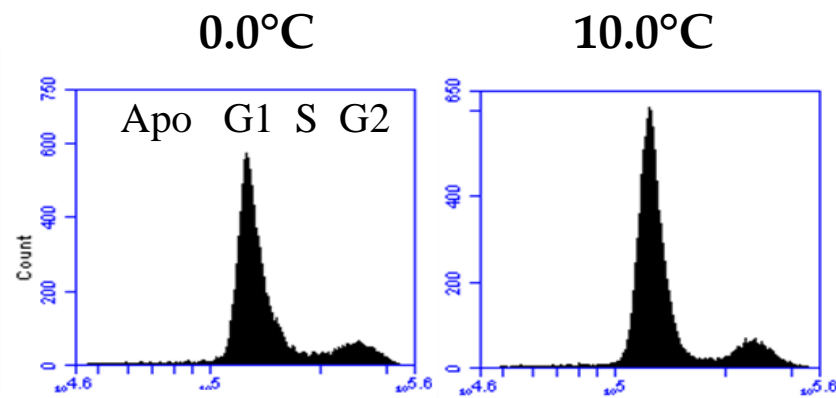

2
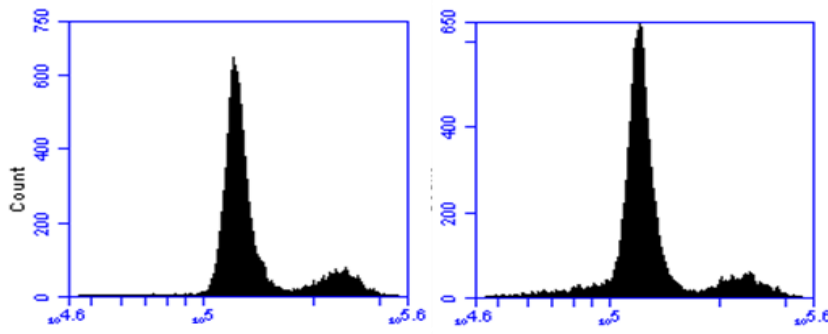

4
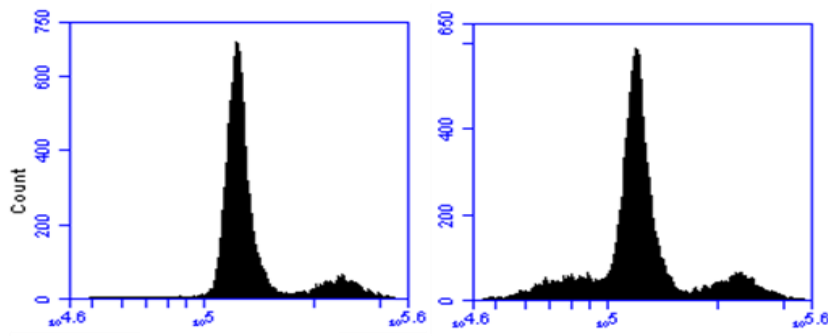

8

宓
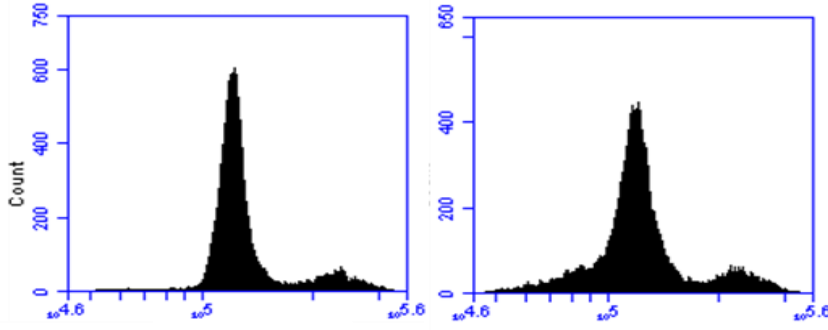

12
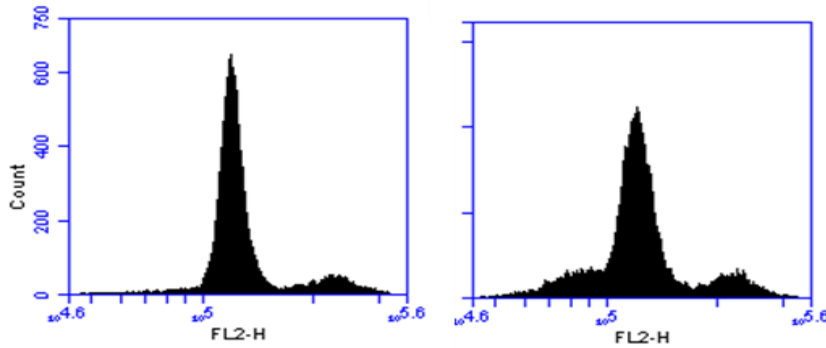

24 
Figure 49. Cell cycle analysis of T. bernacchii hepatocytes held at -2, 0, 2, 6 and $10^{\circ} \mathrm{C}$ for up to $24 \mathrm{~h}$. Lower and upper error bars were removed from $S$ phase and G2 data, respectively, in order to improve readability. ${ }^{*}$ Means were significantly different than the $-2^{\circ} \mathrm{C}$ treatment group (Bonferroni post-test; $p<$ 0.05).

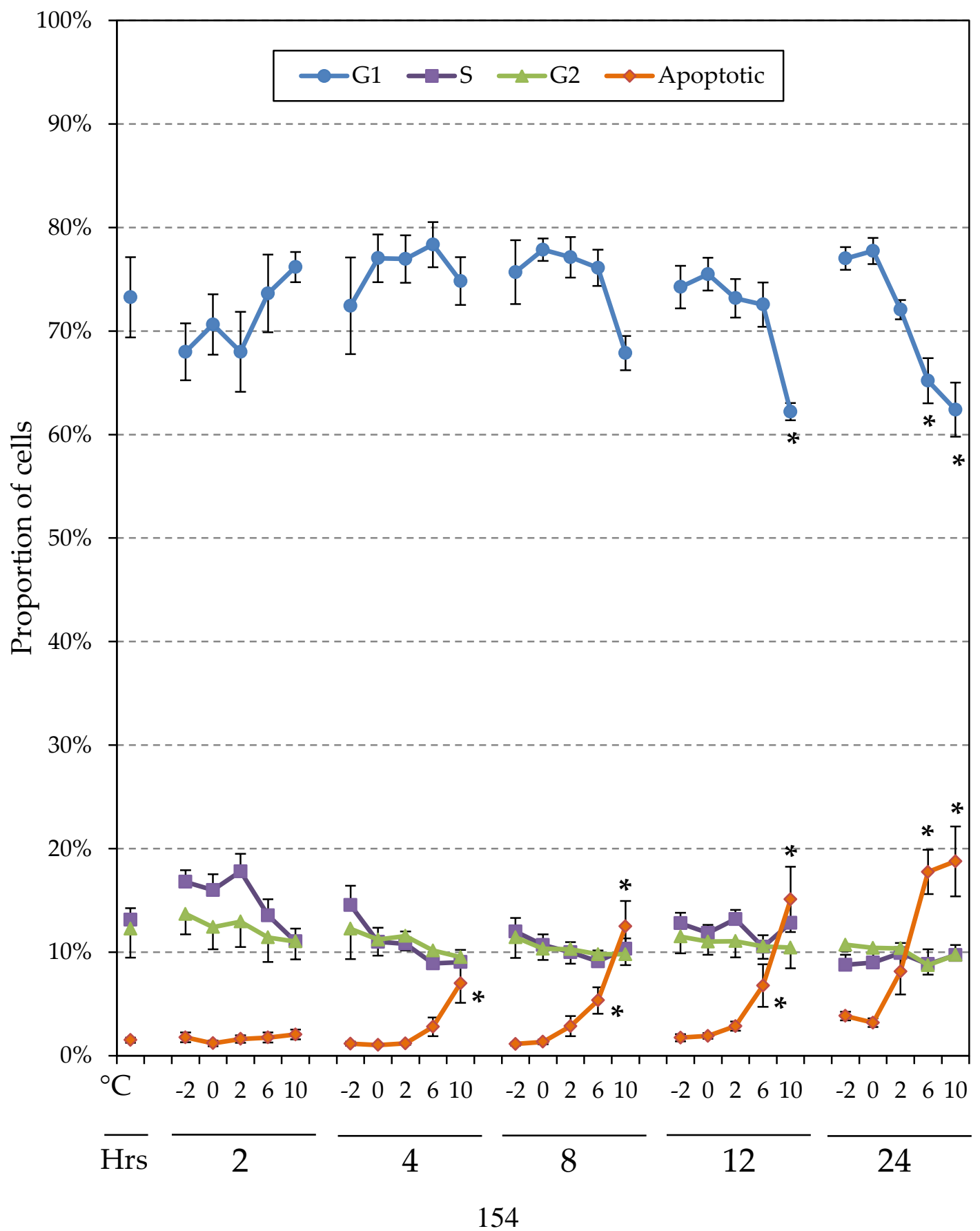


Figure 50. Anti-STAT3 immunoblot of Trematomus bernacchii white muscle tissue during $4.0^{\circ} \mathrm{C}$ heat shock and subsequent recovery at $-1.0 \pm 0.5^{\circ} \mathrm{C}$. The $G$. mirabilis custom anti-STAT3 antibody (recognizing a fourteen-amino-acid sequence at ca. 388-402 within the DNA binding domain) revealed a protein of ca. $40 \mathrm{kDa}$ whose expression varied with temperature treatment.

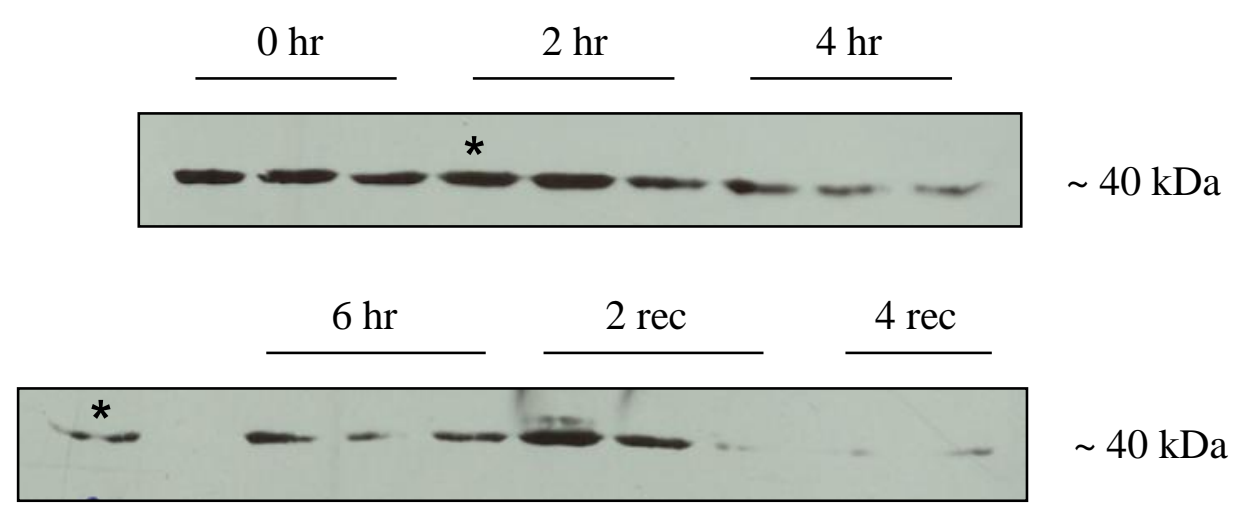


Figure 51. Two different-length film exposures showing anti-STAT3 immunoblots for Rattus norvegicus cell line PC-12 at control $\left(37^{\circ} \mathrm{C}\right)$ and heat shock $\left(2 \mathrm{~h}\right.$ at $44^{\circ} \mathrm{C}$ followed by $5-18 \mathrm{~h}$ recovery at $\left.37^{\circ} \mathrm{C}\right)$. The GM custom antiSTAT3 antibody (recognizing a fourteen-amino-acid sequence at ca. 388-402 within the DNA binding domain) revealed three bands of different molecular weights, all of which decreased following heat shock. The most prominent band, with a molecular weight of ca. $92 \mathrm{kDa}$ is presumed to be full length STAT3. The other two may be isoforms beta $(83 \mathrm{kDa})$ and gamma $(72 \mathrm{kDa})$.

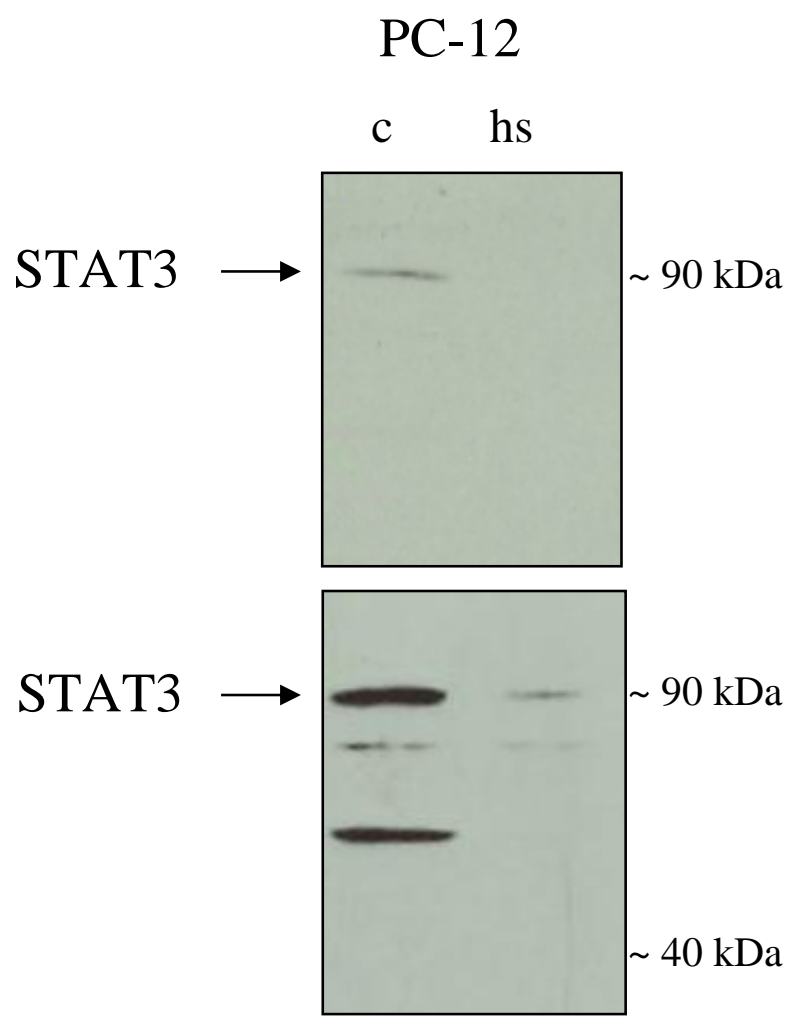


Figure 52. Multi-organism comparison of STAT3, pSTAT3 and related proteins. $\mathrm{Rn}=$ the rat Rattus norvegicus. $\mathrm{Dr}=$ the zebrafish Danio rerio. $\mathrm{Gm}=$ the estuarine goby Gillichthys mirabilis. $\mathrm{Tb}=$ Trematomus bernacchii. Westerns were done on control (non-heat-shocked) PC-12 cells (Rn) or control white muscle tissue (Dr, Gm, Tb). A. A commercial antibody against amino acids (aa) 50-240 of murine STAT3 recognized full-length STAT3 in R. norvegicus and a ca. 40 $\mathrm{kDa}$ STAT3-related protein (STAT3rp) in the fishes. B. An antibody against the highly conserved DNA-binding domain of G. mirabilis STAT3 revealed several proteins of differing size in $R$. norvegicus. These are presumed to be different STAT family members and isoforms thereof. STAT3rp was detected in all three fishes and possibly in $R$. norvegicus, and though this antibody revealed full-length STAT3 in G. mirabilis, STAT3 and related proteins above $40 \mathrm{kDa}$ were not detected in zebrafish or T. bernacchii. C, D. Commercial antibodies against aa 700-750 of phospho-STAT3 detected full-length pSTAT3 (Tyr 705; Ser 727) in R. norvegicus, but nothing in the fishes. However, a low-molecular weight pSTAT3 was detected earlier in T. bernacchii using this same antibody (see figure 5). 
A

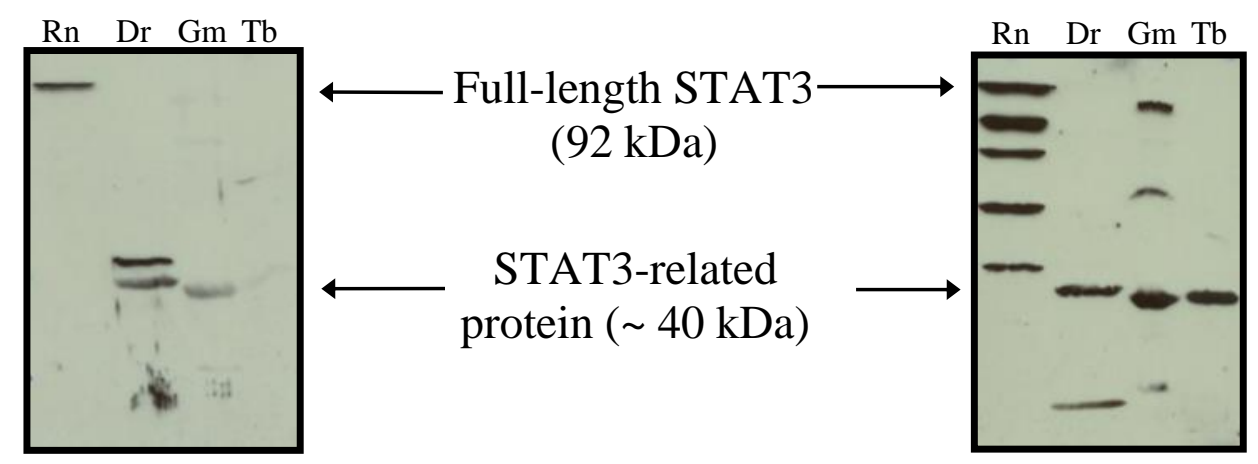

C

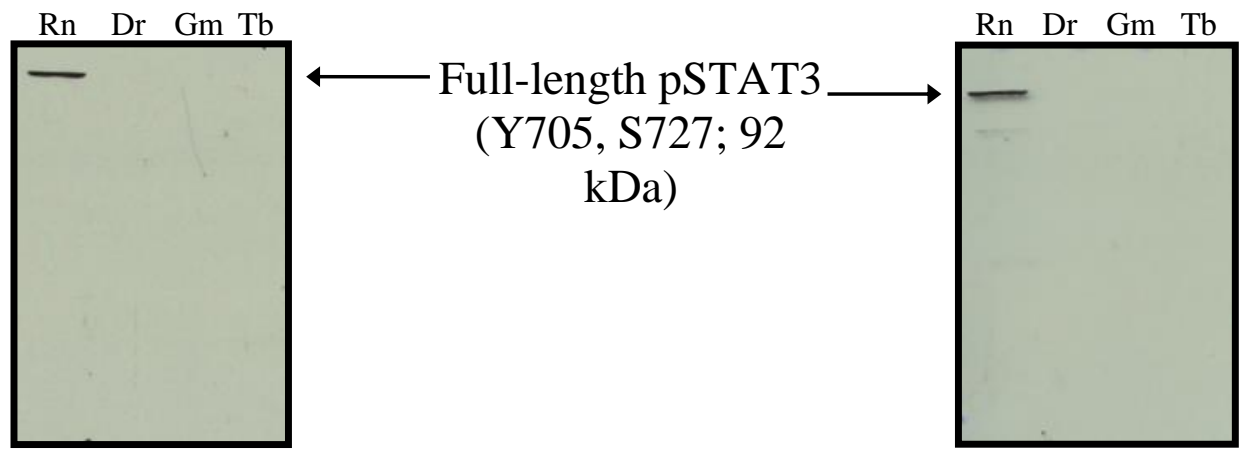

D 
Figure 53. Anti-pSTAT3 immunoblot of Rattus norvegicus cell line PC-12 and Trematomus bernacchii white muscle tissue at control $\left(37^{\circ} \mathrm{C}\right.$ and $-1.86^{\circ} \mathrm{C}$ respectively) and heat shock $\left(44^{\circ} \mathrm{C}\right.$ and $4^{\circ} \mathrm{C}$ respectively). Note that the PC-12 cells recovered for $5-18 \mathrm{~h}$ at $37^{\circ} \mathrm{C}$ before harvesting. The Santa Cruz sc-8001-R antibody (recognizing amino acids 700-750 of mouse STAT3 phosphorylated at Ser 727) revealed two bands in PC-12 cells that disappeared with heat shock. The higher-molecular-weight band is presumed to be PSTAT3 at 92 $\mathrm{kDa}$. In T. bernacchii, full length pSTAT3 was not detected. A low-molecularweight band was detected in one of three control animals and was also present in one individual at $2 \mathrm{~h}$ of heat shock.

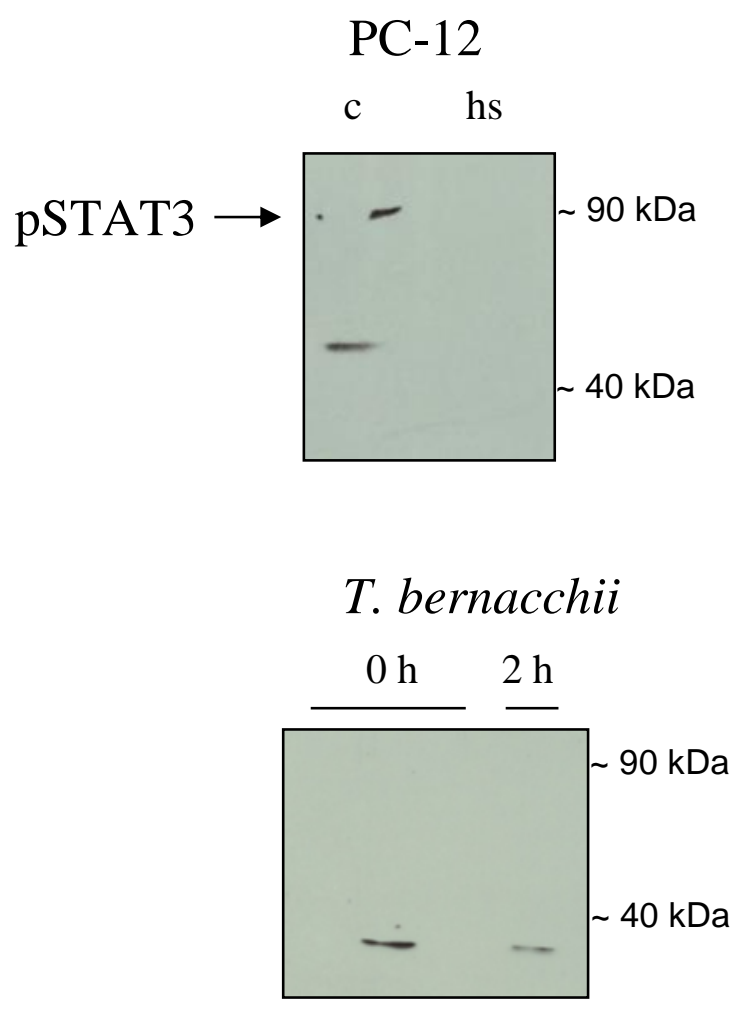




\section{References}

Agrawal, S., Hofmann, W.K., Tidow, N., Ehrich, M., van den Boom, D., Koschmieder, S., Berdel, W.E., Serve, H. and Muller-Tidow, C. (2007). The C/EBP $\delta$ tumor suppressor is silenced by hypermethylation in acute myeloid leukemia. Blood. 109, 3895-3905.

Alberini, C.M., Ghirardi, M., Metz, R. and Kandel, E.R. (1994). C/EBP Is an Immediate-Early Gene Required for the Consolidation of Long-Term Facilitation in Aplysia. Cell. 76, 1099-1114.

Balamurugan, K., Wang, J.M., Tsai, H.H., Sharan, S., Anver, M., Leighty, R. and Sterneck, E. (2010). The tumour suppressor C/EBP $\delta$ inhibits FBXW7 expression and promotes mammary tumour metastasis. EMBO J. 29, 4106-4117.

Barber, A.J., Lieth, E., Khin, S.A., Antonetti, D.A., Buchanan, A.G. and Gardner, T.W. (1998). Neural apoptosis in the retina during experimental and human diabetes. Early onset and effect of insulin. J. Clin. Invest. 102, 783-791.

Beere, H.M. (2005). Death versus survival: functional interaction between the apoptotic and stress-inducible heat shock protein pathways. J. Clin. Invest. 115, 2633-2639.

Billiard, J., Umayahara, Y., Wiren, K., Centrella, M., McCarthy, T.L. and Rotwein, P. (2001). Regulated nuclear-cytoplasmic localization of CCAAT/enhancer-binding protein $\delta$ in osteoblasts. J. Biol. Chem. 276, 15354-15361.

Bilyk, K.T. and DeVries, A.L. (2011). Heat tolerance and its plasticity in Antarctic fishes. J. Comp. Physiol. A. 158, 382-390.

Bosch, T.C., Krylow, S.M., Bode, H.R. and Steele, R.E. (1988). Thermotolerance and synthesis of heat shock proteins: these responses are present in Hydra attenuata but absent in Hydra oligactis. Proc. Natl. Acad. Sci.85, 7927-7931.

Bravo, R., Frank, R., Blundell, P.A. and MacDonald-Bravo, H. (1987). Cyclin/PCNA is the auxiliary protein of DNA polymerase- $\delta$. Nature. 326, 515-517. 
Brodeur, J.C., Calvo, J. and Johnston, I.A. (2003b). Proliferation of myogenic progenitor cells following feeding in the sub-Antarctic notothenioid fish Harpagifer bispinis. J. Exp. Biol. 206, 163-169.

Brodeur, J.C., Calvo, J., Clarke, A. and Johnston, I.A. (2003a). Myogenic cell cycle duration in Harpagifer species with sub-Antarctic and Antarctic distributions: evidence for cold compenstation. J. Exp. Biol. 206, 10111016.

Brodeur, J.C., Peck, L., Johnston, I.A. (2002). Feeding increases MyoD and PCNA expression in myogenic progenitor cells of Notothenia coriiceps. J. Fish Biol. 60, 1475-1485.

Brown, J.H. and Makman, M.H. (1972). Stimulation by Dopamine of Adenylate Cyclase in Retinal Homogenates and of Adenosine-3':5'Cyclic Monophosphate Formation in Intact Retina. Proc. Nat. Acad. Sci. USA. 69, 539-543.

Buckley, B.A. (2010). Acute heat stress and thermal acclimation induce CCAAT/enhancer-binding protein delta in the goby Gillichthys mirabilis. J. Comp. Physiol. B. 181, 773-780.

Buckley, B.A. and Somero, G.N. (2009). cDNA microarray analysis reveals the capacity of the cold-adapted Antarctic fish Trematomus bernacchii to alter gene expression in response to heat stress. Polar Biol. 32, 403-415.

Buckley, B.A., Gracey, A.Y. and Somero, G.N. (2006). The cellular response to heat stress in the goby Gillichthys mirabilis: a cDNA microarray and protein-level analysis. J. Exp. Biol. 209, 2660-2677.

Buckley, B.A., Place, S.P. and Hofmann, G.E. (2004). Regulation of heat shock genes in isolated hepatocytes from an Antarctic fish, Trematomus bernacchii. J. Exp. Biol. 207, 3649-3656.

Cantwell, C. A., Sterneck, E. and Johnson, P. F. (1998). Interleukin-6-specific activation of the C/EBP- $\delta$ gene in hepatocytes is mediated by Stat 3 and Sp1. Mol. Cell. Biol. 18, 2108-2117.

Cardinaux, J.R. and Magistretti, P.J. (1996). Vasoactive intestinal peptide, pituitary adenylate cyclase-activating peptide, and noradrenaline induce the transcription factors CCAAT/enhancer binding protein (C/EBP)-beta and C/EBP delta in mouse cortical astrocytes: involvement in cAMP-regulated glycogen metabolism. J. Neurosci. 16, 919-929.

Castilho, P.C., Buckley, B.A., Somero, G.N. and Block, B.A. (2009). Heterologous hybridization to a complementary DNA microarray 
reveals the effect of thermal acclimation in the endothermic bluefin tuna (Thunnus orientalis). Mol Ecol. 18, 2092-2102.

Celis, J.E. and Celis, A. (1985). Cell cycle-dependent variations in the distribution of the nuclear protein cyclin proliferating cell nuclear antigen in cultured cells: subdivision of S phase. PNAS. 82, 3262-3266.

Chen, Z., Cheng, C.H.C., Zhang, J., Cao, L., Chen, L., Zhou, L., Jin, Y., Ye, H., Deng, C., Dai, Z., Xu, W., Hu, Pl., Sun, S., Shen, Y. and Chen, L. (2008). Transcriptomic and genomic evolution under constant cold in Antarctic notothenioid fish. Proc. Natl. Acad. Sci. 105, 12944-12949.

Coppes Petricorena, Z.L. and Somero, G.N. (2007). Biochemical adaptations of notothenioid fishes: Comparisons between cold temperate South American and New Zealand species and Antarctic species. Comp. Biochem. Phys. A. 147, 799-807.

Cretu, A., Sha, X., Tront, J., Hoffman, B. and Liebermann, D.A. (2009). Stress sensor Gadd45 genes as therapeutic targets in cancer. Cancer Ther. 7, 268-276.

Darlington, G.J., Ross, S.E. and MacDougald, O.A. (1998). The Role of C/EBP Genes in Adipocyte Differentiation. J. Biol. Chem. 273, 30057-30060.

Darnowski, J.W., Goulette, F.A., Guan, Y., Chatterjee, D., Yang, Z., Cousens, L.P., and Chin, Y.E. (2006). Stat3 cleavage by caspases: impact on fulllenth Stat3 expression, fragment formation, and transcriptional activity. J. Biol. Chem. 281, 17707-17717.

Darzynkiewicz, Z., Bruno, S., Del Bino, G., Gorczyca, W., Hotz, M.A., Lassota, P. and Traganos, F. (1992). Features of apoptotic cells measured by flow cytometry. Cytom. Part A. 13, 795-808.

Darzynkiewicz, Z., Juan, G. and Bedner, W. (1999). Determining cell cycle stages by flow cytometry. Curr. Prot. Cell. Biol. 8, 1-18.

Davison, W., Franklin, C.E. and McKenzie, J.C. (1994). Haematological changes in an Antarctic teleost, Trematomus bernacchii, following stress. Polar Biol. 14, 463-466.

DeConto, R.M. and Pollard, D. (2003). Rapid Cenozoic glaciation of Antarctica induced by declining atmospheric $\mathrm{CO}_{2}$. Nature. 421, 245-249.

Desalvo, M.K., Voolstra, C.R., Sunagawa, S., J.A. Schwarz, Stillman, J.H., Coffroth, M.A., Szmant, A.M. and Medina, M. (2008). Differential gene expression during thermal stress and bleaching in the Caribbean coral Montastraea faveolata. Mol. Ecol. 17, 3952-3971. 
Detrich, H.W., Parker, S.K., Williams, R.C., Nogales, E., and Downing, K.H. (2000). Cold adaptation of microtubule assembly and dynamics. J. Biol. Chem. 275, 37038-37047

DeVries, A. (1971). Glycoproteins as biological antifreeze agents in Antarctic fishes. Science. 172, 1152-1155.

Diehl, A.M. (1998). Roles of CCAAT/enhancer-binding proteins in regulation of liver regenerative growth. J. Biol. Chem. 273, 30843-30846.

Dietrich, C., Bartsch, T., Schanz, F., Oesch, F. and Wieser, R.J. (1996). p53Dependent cell cycle arrest induced by $\mathrm{N}$-acetyl-L-leucinyl-L-leucinylL-norleucinal in platelet-derived growth factor-stimulated human fibroblasts. Proc. Natl. Acad. Sci. USA. 93, 10815-10819.

Eastman, J. T. (1993). Antarctic fish biology: evolution in a unique environment. New York: Academic Press.

Eastman, J.T. (2005). The nature of the diversity of Antarctic fishes. Polar biol. 28, 93-107.

Eastman, J.T. and McCune, A.R. (2000). Fishes on the Antarctic continental shelf: evolution of a marine species flock? J. Fish Biol. 57, 84-102.

Engeszer, R.E., Patterson, L.B., Rao, A.A. and Parichy, D.M. (2007). Zebrafish in the Wild: A Review of Natural History and New Notes from the Field. Zebrafish. 4, 21-38.

Eschmeyer, W.N., Herald, E.S. and Hammann, H. (1983). A field guide to Pacific coast fishes of North America. Boston: Houghton Mifflin Company.

Evans, T. and Somero, G.N. (2008). A microarray-based transcriptomic timecourse of hyper- and hypo-osmotic stress signaling events in the euryhaline fish Gillichthys mirabilis: osmosensors to effectors. J. Exp. Biol. 211, 3636-3649.

Feder, M.E. and Hofmann, G.E. (1999). Heat-shock proteins, molecular chaperones, and the stress response: evolutionary and ecological physiology. Annu. Rev. Physiol. 61, 243-282.

Fernández , D.A. and Calvo, J. (2009). Fish muscle: the exceptional case of notothenioids. Fish Physiol. Biochem. 35, 43-52.

Fields, P.A. and Somero, G.N. (1998). Hot spots in cold adaptation: localized increases in conformational flexibility in lactate dehydrogenase $\mathrm{A}_{4}$ orthologs of Antarctic notothenioid fishes. Proc. Nat. Acad. Sci. 95, 11476-11481.

Fink, A.L. (1999). Chaperone-mediated protein folding. Physiol. Rev. 79: 425449. 
Fischer, D., Petkova, V., Thanos, S. and Benowitz, L.I. (2004). Switching Mature Retinal Ganglion Cells to a Robust Growth State In Vivo: Gene Expression and Synergy with RhoA Inactivation. J. Neurosci. 24, 87268740.

Forster, M.E., Davison, W., Axelsson, M., Sundin, L., Franklin, C.E. and Gieseg, S. (1998). Catecholamine release in heat-stressed Antarctic fish causes proton extrusion by the red cells. J. Comp. Physiol. B. 168, 345352.

Franklin, C.E., Davison, W. and Seebacher, F. (2007). Antarctic fish can compensate for rising temperatures: thermal acclimation of cardiac performance in Pagothenia borchgrevinki. J. Exp. Biol. 210, 3068-3074.

Garrido, C., Gurbuxani, S., Ravagnan, L. and Kroemer, G. (2001). Heat Shock Proteins: Endogenous Modulators of Apoptotic Cell Death. Biochem. Biophys. Res. Co. 286, 433-442.

Gavrieli, Y., Sherman, Y. and Ben-Sasson, S.A. (1992). Identification of programmed cell death in situ via specific labeling of nuclear DNA fragmentation. J. Cell Biol. 119, 493-501.

Gerhardinger, C., Biarnés Costa, M., Coulombe, M.C., Toth, I., Hoehn, T. and Grosu, P. (2005). Expression of Acute-Phase Response Proteins in Retinal Müller Cells in Diabetes. Invest. Ophthalmol. Vis. Sci. 46, 349-357.

Gracey, A.Y., Chaney, M.L., Boomhower, J.P., Tyburczy, W.R., Connor, K. and Somero, G.N. (2008). Rhythms of Gene Expression in a Fluctuating Intertidal Environment. Curr. Biol. 18, 1501-1507.

Gracey, A.Y., Fraser, E.J., Li, W., Li, W., Fang, Y., Taylor, R.R., Rogers, J., Brass, A. and Cossins, A.R. (2004). Coping with cold: An integrative, multitissue analysis of the transcriptome of a poikilothermic vertebrate. Proc. Natl. Acad. Sci. 101, 16970-16975.

Gracey, A.Y., Troll, J.V. and Somero, G.N. (2001). Hypoxia-induced gene expression profiling in the euryoxic fish Gillichthys mirabilis. Proc. Nat. Acad. Sci. 98, 1993-1998.

Hall, P.A., Levison, D.A., Woods, A.L., Yu, C.C.-W., Kellock, D.B., Watkins, J.A., Barnes, D.M., Gillett, C.E., Camplejohn, R., Dover, R., Waseem, N.H. and Lane, D.P. (1990). Proliferating cell nuclear antigen (PCNA) immunolocalization in paraffin sections: An index of cell proliferation with evidence of deregulated expression in some neoplasms. J. Pathol. $162,285-294$. 
Harris, T.E., Albrecht, J.H., Nakanishi, M. and Darlington, G.J. (2001). CCAAT/Enhancer-binding Protein- $\alpha$ Cooperates with p21 to Inhibit Cyclin-dependent Kinase-2 Activity and Induces Growth Arrest Independent of DNA Binding. J. Biol. Chem. 276, 29200-29209.

Henle, E.S. and Linn, S. (1997). Formation, Prevention, and Repair of DNA Damage by Iron/Hydrogen Peroxide. J. Biol. Chem. 272, 19095-19098.

Hochachka, P.W. and Somero, G.N. (2002). Biochemical Adaptation: Mechanism and Process in Physiological Evolution. $3^{\text {rd }}$ edition. Oxford: Oxford University Press.

Hodge, D.R., Hurt, E.M., and Farrar, W.L. (2005). The role of IL-6 and STAT3 in inflammation and cancer. Eur. J. Cancer. 41, 2502-2512.

Hoffman, G.E. and Somero, G.N. (1995). Evidence for protein damage at environmental temperatures: seasonal changes in levels of ubiquitin conjugates and hsp70 in the intertidal mussel Mytilus trossulus. J. Exp. Biol. 198, 1509-1518.

Hofmann, G.E., Buckley, B.A., Airaksinen, S., Keen, J.E. and Somero, G.N. (2000). Heat-shock protein expression is absent in the Antarctic fish Trematomus bernacchii (family Nototheniidae). J. Exp. Biol. 203, 23312339.

Huang, A., Montagna, C., Sharan, S., Ni, Y., Ried, T. and Sternck, E. Loss of CCAAT/enhancer binding protein $\delta$ promotes chromosomal instability. Oncogene. 23, 1549-1557.

Hungness, E.S., Robb, B.W., Luo, G.J., Pritts, T.A., Hershko, D.D. and Hasselgren, P.O. (2002). Proteasome Inhibitors Activate the Transcription Factors C/EBP- $\beta$ and $\delta$ in Human Intestinal Epithelial Cells. Biochem. Biophys. Res. Com. 290, 469-474.

Hutt, J.A., O'Rourke, J.P. and DeWille, J. (2000). Signal Transducer and Activator of Transcription 3 Activates CCAAT Enhancer-binding Protein $\delta$ Gene Transcription in GoGrowth-arrested Mouse Mammary Epithelial Cells and in Involuting Mouse Mammary Gland. J. Biol. Chem. 275, 29123-29131.

Ikezoe, T., Gery, S., Yin, D., O'Kelly, J., Binderup, L., Lemp, N., Taguchi, H. and Koeffler, H.P. (2005). CCAAT/enhancer-binding protein $\delta:$ a molecular target of 1,25-dihydroxyvitamin $\mathrm{D}_{3}$ in androgen-responsive prostate cancer LNCaP cells. Cancer Res. 65, 4762-4768. 
Isenmann, S. and Bähr, M. (1997). Expression of c-Jun Protein in Degenerating Retinal Ganglion Cells after Optic Nerve Lesion in the Rat. Exp. Neurol. 147, 28-36.

Johnson, P.F. (2005). Molecular stop signs: regulation of cell-cycle arrest by C/EBP transcription factors. J. Cell Sci. 118, 2545-2555.

Johnston, I.A. (2006). Environment and plasticity of myogenesis in teleost fish. J. Exp. Biol. 209, 2249-2264.

Johnston, I.A., Fernández, D.A., Calvo, J., Vieira, V.L.A., North, A.W., Abercromby, M., and Garland Jr., T. (2003b). Reduction in muscle fibre number during the adaptive radiation of notothenioid fishes: a phylogenetic perspective. J. Exp. Biol. 206, 2595-2609.

Johnston, I.A., Vieira, V.L.A., Fernandez, D., Abercromby, M., Brodeur, J.C., Peck, L.S. and Calvo, J. (2003a). Muscle growth in polar fish: a study of Harpagifer species with sub-Antarctic and Antarctic distributions. Fish. Sci. 68, 1023-1028.

Kassahn, K.S., Caley, M.J., Ward, A.C., Connolly, A.R., Stone, G. and Crozier, R.H. (2007). Heterologous hybridization to study the early gene response to heat stress in a coral reef fish. Mol. Ecol. 16, 1749-1763.

Kennett, J.P. (1977).Cenezoic evolution of Antarctic glaciation, the circumAntarctic Ocean, and their impact on global paleoceanography. J. Geophys. Res. 82, 3843-3860.

Kimura, S.H., Ikawa, M., Ito, A., Okabe, M. and Nojima, H. (2001). Cyclin G1 is involved in G2/M arrest in response to DNA damage and in growth control after damage recovery. Oncogene. 20, 3290-3300.

Koumans, J.T.M. and Akster, H.A. (1995). Myogenic cells in development and growth of fish. Comp. Biochem. Physiol. A. 110, 3-20.

Krishna, T.S.R., Kong, X.P., Gary, S., Burgers, P.M. and Kuriyan, J. (1994). Crystal structure of the eukaryotic DNA polymerase processivity factor PCNA. Cell. 79, 1233-1243.

Kültz, D. (2005). Molecular and evolutionary basis of the cellular stress response. Annu. Rev. Physiol. 67, 225-257.

Kurki, P., Vanderlaan, M., Dolbeare, F., Gray, J., and Tan, E.M. (1986). Expression of proliferating cell nuclear antigen (PCNA)/cyclin during the cell cycle. Exp. Cell Res. 166, 209-219.

Landini, G. (2010). Color Deconvolution. University of Birmingham School of Dentistry. Retrieved May 2, 2011, from 
http://www.dentistry.bham.ac.uk/landinig/software/cdeconv/cdeconv. html.

Lane, M.D., Tang, Q.Q. and Jiang, M.S. Role of the CCAAT Enhancer Binding Proteins (C/EBPs) in Adipocyte Differentiation. (1999). Biochem. Biophys. Res. Commun. 266, 677-683.

Lekstrom-Himes, J. and Xanthopolous, K.G. (1998). Biological role of the CCAAT/enhancer-binding protein family of transcription factors. J. Biol. Chem. 273, 28545-28548.

Lesser, M.P. (2006). Oxidative stress in marine environments: biochemistry and physiological ecology. Annu. Rev. Physiol. 68, 253-278.

Li, R., Strohmeyer, R., Liang, Z., Lue, L.F. and Rogers, J. (2004). CCAAT/enhancer binding protein $\delta(\mathrm{C} / \mathrm{EBP} \delta)$ expression and elevation in Alzheimer's disease. Neurobiol. Aging. 25, 991-999.

Lim, C.P. and Cao, X. (2006). Structure, function, and regulation of STAT proteins. Mol. Biosyst. 2, 536-550.

Lindquist, S. (1986). The heat-shock response. Annu. Rev. Biochem. 55, 11511191.

Livermore, R., Nankivell, A., Eagles, G. and Morris, P. (2005). Paleogene opening of Drake Passage. Earth Planet. Sci. Lett. 236, 459-470.

MacDougald, O.A., Cornelius, Pl, Lin, F.T., Chen, S.S. and Lane, M.D. (1994). Glucocorticoids reciprocally regulate expression of the CCAAT/enhancer-binding protein alpha and delta genes in 3T3-L1 adipocytes and white adipose tissue. J. Biol Chem. 269, 19041-19047.

Maga, G. and Hübscher, U. (2003). Proliferating cell nuclear antigen (PCNA): a dancer with many partners. J. Cell Sci. 116, 3051-3060.

Malek, R.L., Sajadi, H., Abraham, J., Grundy, M.A. and Gerhard, G.S. (2004). The effects of temperature reduction on gene expression and oxidative stress in skeletal muscle from adult zebrafish. Comp. Biochem. Physiol. C. Toxicol. Pharmacol. 138, 363-373.

Martindale, J.L. and Holbrook, N.J. (2002). Cellular response to oxidative stress: Signaling for suicide and survival. J. Cell. Physiol. 192, 1-15.

Matschiner, M., Hanel, R. and Salzburger, W. (2011). On the origin and trigger of the notothenioid adaptive radiation. PLOS ONE. 6, 1-9.

Matsumoto, S., Yanagida, M. and Nurse, P. (1987). Histone transcription in cell cycle mutants of fission yeast. EMBO J. 6, 1093-1097.

Matthews, J.R., Watson, S.M.R., Tevendale, M.C.L., Watson, C.J. and Clarke, A.R. (2007). Caspase-dependent proteolytic cleavage of STAT3 $\alpha$ in ES 
cells, in mammary glands undergoing forced involution and in breast cancer cell lines. BMC Cancer. 7.

Miyachi, K., Fritzler, M.J. and Tan, E.M. (1978). Autoantibody to a Nuclear Antigen in Proliferating Cells. J. Immunol. 121, 2228-2234.

Moh, A., Iwamoto, Y., Chai, G.X., Zhang, S.S., Kano, A., Yang, D.D., Zhang, W., Wang, J., Jacoby, J.J., Gao, B., Flavell, R.A. and Fu, X.Y. (2007). Role of STAT3 in liver regeneration: survival, DNA synthesis, inflammatory reaction and liver mass recovery. Lab. Invest. 87, 1018-1028.

Nerlov, C. (2007). The C/EBP family of transcription factors: a paradigm for interaction between gene expression and proliferation control. Trends cell. Biol. 17, 318-324.

Nowakowski, R.S., Lewin, S.B. and Miller, W. (1989). Bromodeoxyuridine immunohistochemical determination of the lengths of cell cycle and the DNA-synthetic phase for an anatomically defined population. $J$. Neurocytol. 18, 311-318.

Okamura, N.M., Aizawa, S. and Yamaizumi, M. (1997). Heat shock induces transient p53-dependent cell cycle arrest at G1/S. Oncogene. 15, 561-568.

O'Rourke, J., Yuan, R. and DeWille, J. (1997). CCAAT/enhancer-binding protein- $\delta$ is induced in growth-arrested mouse mammary epithelial cells. J. Biol. Chem. 272, 6291-6296.

O'Rourke, J.P., Newbound, G.C., Hutt, J.A. and DeWille, J. (1999). CCAAT/enhancer-binding protein delta regulates mammary epithelial cell Go growth arrest and apoptosis. J. Biol. Chem. 23, 16582-16589.

Oates, A.C., Wollberg, P., Pratt, S.J., Paw, B.H., Johnson, S.L., Ho, R.K., Postlethwait, J.H., Zon, L.I. and Wilks, A.F. (1999). Zebrafish stat3 is expressed in restricted tissues during embryogenesis and stat1 rescues cytokine signaling in a STAT1-deficient human cell line. Dev. Dynam. 215, 352-370.

Pabst, T., Mueller, B.U., Zhang, P., Radomska, H.S., Narravula, S., Schnittger, S., Behre, G., Hiddemann, W. and Tenen, D.G. (2001). Dominantnegative mutations of CEBPA, encoding CCAAT/enhancer binding protein- $\alpha(\mathrm{C} / \mathrm{EBP} \alpha)$, in acute myeloid leukemia. Nat. Genet. 27, 263-270.

Parseghian, M.H. and Luhrs, K.A. (2006). Beyond the walls of the nucleus: the role of histones in cellular signaling and innate immunity. Biochem. Cell. Biol. 84, 589-604.

Pinto, R., Ivaldi, C., Reyes, M., Doyen, C., Mietton, F., Mongelard, F., Alvarez, M., Molina, A., Dimitrov, S., Krauskopf, M., Vera, M.I., and Bouvet, P. 
(2005). Seasonal environmental changes regulate the expression of the histone variant macroH2A in an eurythermal fish. FEBS letters. 579, 5553-5558.

Place, S.P. and Hofmann, G.E. (2004). Constitutive expression of a stressinducible heat shock protein gene, $h s p 70$, in phylogenetically distant Antarctic fish. Polar Biol. 28, 261-267.

Place, S.P., Zippay, M.L. and Hofmann, G.E. (2004). Constitutive roles for inducible genes: evidence for the alteration in expression of the inducible hsp70 gene in Antarctic notothenioid fishes. Am. J. Physiol. 287, R429-R436.

Podrabsky, J.E. and Somero, G.N. (2004). Changes in gene expression associated with acclimation to constant temperatures and fluctuating daily temperatures in an annual killifish Austrofundulus limnaeus. J. Exp. Biol. 207, 2237-2254.

Podrabsky, J.E. and Somero, G.N. (2006). Inducible heat tolerance in Antarctic notothenioid fishes. Polar biol. 30, 39-43.

Poli, V. (1998). The role of C/EBP Isoforms in the Control of Inflammatory and Native Immunity Functions. J. Biol. Chem. 273, 29279-29282.

Porter, D.A., Krop, I.E., Nasser, S., Sgroi, D., Kaelin, C.M., Marks, J.R., Riggins, G. and Polyak, K. (2001). A SAGE (Serial analysis of gene expression) view of breast tumor progression. Cancer Res. 61, 5697-5702.

Porter, D.A., Lahit-Domenici, J., Keshaviah, A., Bae, Y.K., Argani, P., Marks, J., Richardson, A., Cooper, A., Strausberg, R., Riggeins, G.J., Schnitt, S., Gabrielson, E., Gelman, R. and Polyak, K. (2003). Molecular markers in ductal carcinoma in situ of the breast. Mol. Cancer Res. 1, 362-375.

Pörtner, H.A., Peck, L. and Somero, G.N. (2007). Thermal limits and adaptation in marine Antarctic ectotherms: an integrative view. Phil. Trans. R. Soc. B. 362, 2233-2258.

Pörtner, H.O. and Knust, R. (2007). Climate Change Affects Marine Fishes Through the Oxygen Limitation of Thermal Tolerance. Science. 315, 9597.

Ramji, D.P. and Foka, P. (2002). CCAAT/enhancer-binding proteins: structure, function and regulation. Biochem. J. 365, 561-575.

Richier, S., Rodriquez-Lanetty, M., Schnitzler, C.E. and Weis, V.M. (2008). Response of the symbiotic cnidarian Anthopleura elegantissima transcriptome to temperature and UV increase. Comp Biochem Phys D. 3, 283-289. 
Rutschmann, S., Matschiner, M., Damerau, M., Muschick, M., Lehmann, M.F., Hanel, R., Salzburger, W. (2011). Parallel ecological diversification in Antarctic notothenioid fishes as evidence for adaptive radiation. Mol. Ecol. 20, 4707-4721.

Sabatakos, G., Davies, G. E., Grosse, M., Cryer, A. and Ramji, D. P. (1998). Expression of the genes encoding CCAAT-enhancer binding protein isoforms in the mouse mammary gland during lactation and involution. Biochem. J. 334, 205-210.

Seebacher, F., Davison, W., Lowe, C.J. and Franklin, C.E. (2005). A falsification of the thermal specialization paradigm: compensation for elevated temperatures in Antarctic fishes. Biology Lett. 1, 151-154.

Shevenell, A.E., Kennett, J.P. and Lea, D.W. (2004). Middle Miocene Southern Ocean cooling and Antarctic cryosphere expansion. Science. 305, 17661770.

Shivji, K.K., Kenny, M.K. and Wood, R.D. Proliferating cell nuclear antigen is required for DNA excision repair. Cell. 69, 367-374.

Sidell, B.D. and O'Brien, K.M. (2006). When bad things happen to good fish: the loss of hemoglobin and myoglobin expression in Antarctic icefishes. J. Exp. Biol. 209, 1791-1802.

Skugor, S., Glover, K.A., Nilsen, F. and Krasnov, A. (2008). Local and systemic gene expression responses of Atlantic salmon (Salmo salar L.) to infection with the salmon louse (Lepeophtheirus salmonis). BMC genomics. 9:498.

Sleadd, I.M. and Buckley, B.A. (2012). The CCAAT/enhancer-binding protein $\delta$ $(\mathrm{C} / \mathrm{EBP}-\delta)$ transcription factor is heat inducible in the cold-adapted antarctic fish Trematomus bernacchii. Polar Biol. 10.1007/s00300-012-12628.

Smith, M.L., Chen, I.T., Zhan, Q., Bae, I., Chen, C.Y., Gilmer, T.M., Kastan, M.B., O'Connor P.M. and Fornace, A.J. Jr. (1994). Interaction of the p53regulated protein Gadd45 with proliferating cell nuclear antigen. Science. 266, 1376-1380.

Somero, G.N. and DeVries, A.L. (1967). Temperature tolerance of some Antarctic fishes. Science. 156, 257-258.

Somero, G.N. and Hochachka, P.W. (1968). The effect of temperature on catalytic and regulatory functions of pyruvate kinases of the rainbow trout and the Antarctic fish Trematomus bernacchii. Biochem. J. 110, 395400 . 
Spence, R., Gerlach, G., Lawrence, C. and Smith, C. (2007). The behavior and ecology of the zebrafish, Danio rerio. Biol. Rev. 83, 13-34.

Sterneck, E., Paylor, R., Jackson-Lewis, V., Libbey, M., Przedborski, S., Tessarollo, L., Crawley, J.N. and Johnson, P.F. (1998). Selectively enhanced contextual fear conditioning in mice lacking the transcriptional regulator CCAAT/enhancer binding protein $\delta$. P. Natl. Acad. Sci. USA.

Sun, Y., Jia, L., Williams, M.T., Zamzow, M., Ran, H., Quinn, B., Aronow, B.J., Vorhees, C.V., Witte, D.P. and Grabowski, G.A. Temporal gene expression profiling reveals CEBPD as a candidate regulator of brain disease in prosaposin deficient mice. BMC Neurosci. 9.

Taylor, C.R. and Levenson, R.M. (2006). Quantification of immunohistochemistry-issues concerning methods, utility and semiquantitative assessment II. Histopathology. 49, 411-424.

Tezel, G. and Wax, M.B. (2000). Increased Production of Tumor Necrosis Factor- $\alpha$ by Glial Cells Exposed to Simulated Ischemia or Elevated Hydrostatic Pressure Induces Apoptosis in Cocultured Retinal Ganglion Cells. J. Neurosci. 20, 8693-8700.

Thangaraju, M., Rudelius, M., Bierie, B., Raffeld, M., Sharan, S., Hennighausen, L., Huang, A. and Sterneck, E. (2005). C/EBP $\delta$ is a crucial regulator of pro-apoptotic gene expression during mammary gland involution. Development. 132, 4675-4685.

Todgham, A.E., Hoaglund, E.A and Hofmann, G.E. (2007). Is cold the new hot? Elevated ubiquitin-conjugated protein levels in tissues of Antarctic fish as evidence for cold-denaturation of proteins in vivo. J. Comp. Physiol. B. 177, 857-66.

von Gertten, C., Morales, A.F., Holmin, S., Mathiesen, T. and Sandberg Nordqvist, A.C. (2005). Genomic responses in rat cerebral cortex after traumatic brain injury. BMC Neurosci. 6.

Vornanen, M., Hassinen, M., Koskinen, H. and Krasnov, A. (2005). Steadystate effects of temperature acclimation on the transcriptome of the rainbow trout heart. Am. J. Physiol. Regul. Integr. Comp. Physiol. 289, R1177-R1184.

Wendelaar Bonga, S.E. (1997). The stress response in fish. Physiol. Rev. 77, 591625.

Westerfield, M. (2007). The Zebrafish Book: A guide for the laboratory use of zebrafish (Danio rerio). Eugene, OR: University of Oregon Press. 
Yamada, T., Tobita, K., Osada, S., Nishihara, T. and Imagawa, M. (1997). CCAAT/enhancer binding protein $\delta$ gene expression is mediated by APRF/STAT3. J. Biochem (Tokyo). 121, 731-738.

Yin, M., Yang, S.Q., Lin, H.Z., Lane, M.D., Chatterjee, S. and Diehl, A.M. (1996). Tumor Necrosis Factor $\alpha$ Promotes Nuclear Localization of Cytokine-inducible CCAAT/Enhancer Binding Protein Isoforms in Hepatocytes. J. Biol. Chem. 271, 17974-17978.

Zachos, J., Pagani, M., Sloan, L., Thomas, E. and Billups, K. (2001). Trends, rhythms, and aberrations in global climate change $65 \mathrm{MA}$ to present. Science. 292, 686-693.

Zhang, Y., Liu, T., Yan, P., Huang, T. and DeWille, J. (2008). Identification and characterization of CCAAT/Enhancer Binding protein delta (C/EBP delta) target genes in Go growth arrested mammary epithelial cells. BMC Mol. Biol. 9. 


\section{Appendix: Preliminary investigations of Stat3}

Western blots were used to investigate in fishes the expression of a known regulator of C/EBP-delta, namely, signal transducer and activator of transcription 3 (Stat3; Yamada et al., 1997). This protein has reasonably wellcharacterized roles in both normal and disease states (Oats et al., 1999; Hodge et al., 2005; Lim et al., 2006; Moh et al., 2007). An antibody against the well conserved DNA-binding domain of G. mirabilis Stat3 (Gm-Stat3) failed to detect full-length Stat3 (Stat3 $\alpha ; 92 \mathrm{kDa})$ in T. bernacchii, instead revealing a single band of ca. $40 \mathrm{kDa}$ that varied in response to heat treatment (Fig. 50). This same antibody was able to detect Stat $3 \alpha$ in rat (Rattus norvegicus) PC-12 cells (Fig. 51) and G. mirabilis white muscle (Fig. 52), affirming the antibody's affinity towards this protein. In addition to Stat $3 \alpha$, the anti-GM-Stat 3 antibody revealed in rat PC-12 cells two bands between ca. 60 and $90 \mathrm{kDa}$, and all three bands decreased in intensity with heat shock and subsequent recovery (Fig. 51). When the primary antibody concentration was increased, two additional bands (five total) appeared in control (unstressed; $37^{\circ} \mathrm{C}$ ) rat PC-12 cells, one of which was present at ca. $40 \mathrm{kDa}$. Most or all of these bands were absent in the fishes T. bernacchii, G. mirabilis, and D. rerio (Fig. 52). Commercial antibodies against aa 700-750 of phospho-Stat3 detected full-length pStat3 (Tyr 705; Ser 727) in R. norvegicus, but nothing in the fishes (Fig. 52); however, a lowmolecular weight pStat3-related protein (Ser 727) was detected earlier in $T$. bernacchii using this same antibody (Fig. 52). The anti-pStat3 (Ser 727) antibody revealed two bands in PC-12 cells that disappeared with heat shock (Fig. 53). In T. bernacchii, full length pStat 3 was not detected. A low-molecular-weight band was detected in one of three control animals and was also present in one individual at $2 \mathrm{hrs}$ of heat shock (Fig. 53). Importantly and in summary, none of the antibodies were able to detect full-length Stat 3 in $D$. rerio or T. bernacchii white muscle, instead revealing only a ca. $40 \mathrm{kDa}$ related protein that was present also in G. mirabilis and perhaps in R. norvegicus. There are some reports of low molecular weight protein products that result from cleavage of full-length Stat3 by caspases (Darnowski et al., 2006; Matthews et al., 2007), and future work would be required to determine whether this is physiologically important in fishes. 